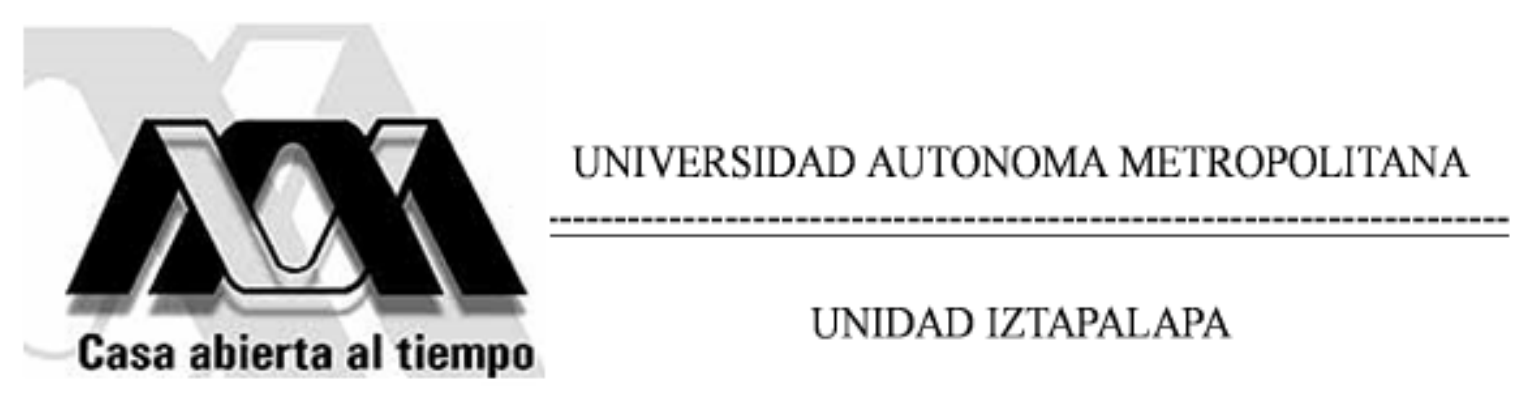

DIVISIÓN DE CIENCIAS BIOLÓGICAS Y DE LA SALUD

MAESTRÍA EN BIOLOGÍA DE LA REPRODUCCIÓN ANIMAL

"Análisis morfológico del epidídimo y determinación espermática durante la postsaciedad sexual de la rata"

TESIS

PARA OBTENER EL GRADO DE:

MAESTRA EN BIOLOGÍA DE LA REPRODUCCIÓN ANIMAL

P R E S E N T A :

Biól. Yolanda López Ramírez

\begin{abstract}
Comité Tutoral
CODIRECTOR: Dr. Mario García Lorenzana

CODIRECTORA: Dra. Rosa Angélica Lucio Lucio

ASESORA: Dra. Edith Arenas Ríos
\end{abstract}


AkALISIS MDPROTOGICO DEL RETDTDIMO Y DeTEKMINACTCN ESEEANSTICA DCTANTE ILS POGTSACIBDAD SEXUAL DE LA RATA.
En 1a Ciudad de Mexiee, se prementaron a las 10100 horas del dia 26 del mes de nayo del ano 2017 en la Unitad 1ztopalspa de la Oniversidad Auténona Metropolitans, 10 s suscritos nientros del jursdot

tosh. EDITM Aarsus RTOS

DRh. AMBAEL JIMENE2 LNGUIANC

DeA. YOLBMEA CRUz COCEg

DR. JOSE LUIS TLACHI LCEEZ

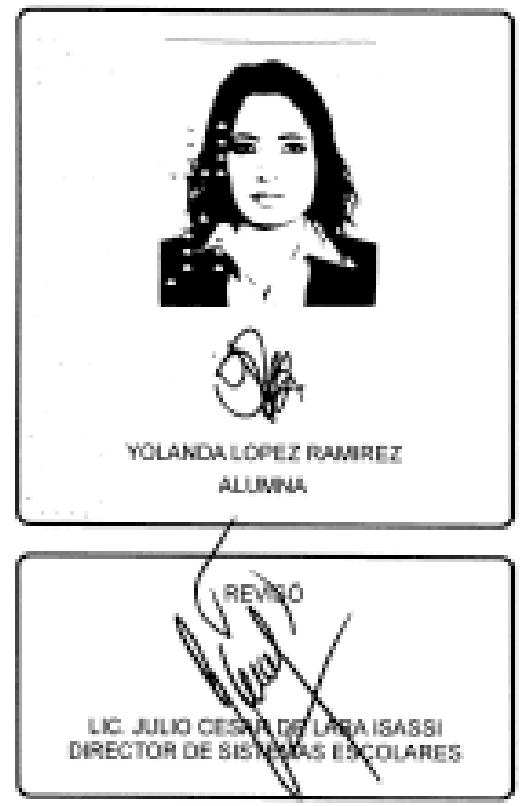

Bayo 1a Dresidencia de lo primers o con caractex de Secretario el últino, ae reunieran para proceder ol Exaren de Grado euya denoninación aparece al margen, pera la obtención del grado de:

MUESTPA EN BIOLOGLA DE IA REDRODUCCTON ANTMAL

DE; YOLANDA LOPES BANIMEZ

$y$ de atukrdo con el articulo 78 fraceion III del Reglanento de Eatudioa Superiares de la Oniversidad Autóncea Metropolitans, 100 nienbros del jazado resolvieron:

\section{Aprobar}

keto continuo, la presidenta del jurado coannios a la interessdo el resultado de la araluacion $y_{e}$ en $\cos 0$ aprobatorio, to fue tanads 1a protesta.

DRECTORA DE LA OMSON DE CBS

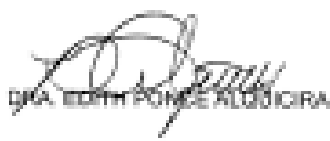

PRES DENTA

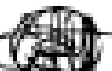

DRA EDTHARENAS ROS
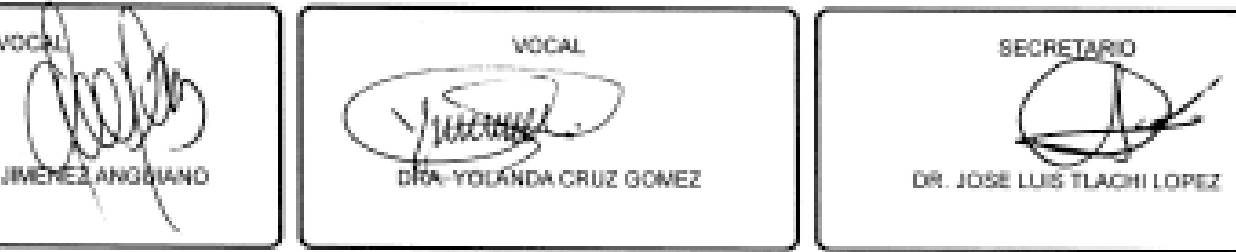

De. JOSE US TLAOMIIOPI 
COMITÉ TUTORAL

CODIRECTORES:

\section{Dr. Mario García Lorenzana}

División de Ciencias Biológicas y de la Salud.

Departamento de Biología de la Reproducción.

Correo electrónico:mglo@xanum.uam.mx

UAM-Iztapalapa

\section{Dra. Rosa Angélica Lucio Lucio}

Centro Tlaxcala de Biología de la Conducta

Correo electrónico: lucioral@yahoo.com.mx

UAT

\section{ASESORA:}

\section{Dra. Edith Arenas Ríos}

División de Ciencias Biológicas y de la Salud.

Departamento de Biología de la Reproducción.

Correo electrónico: editharenas2000@yahoo.com.mx

UAM-Iztapalapa 


\title{
JURADO DE EXAMEN
}

\author{
Dra. Edith Arenas Ríos \\ División de Ciencias Biológicas y de la Salud. \\ Departamento de Biología de la Reproducción. \\ Correo electrónico: editharenas2000@yahoo.com.mx \\ UAM-Iztapalapa

\section{Dr. José Luis Tlachi López} \\ División de Ciencias Biológicas y de la Salud. \\ Departamento de Biología de la Reproducción. \\ Correo electrónico: tlachij|@yahoo.com \\ UAM-Iztapalapa
}

\section{Dra. Anabel Jiménez Anguiano}

División de Ciencias Biológicas y de la Salud.

Departamento de Biología de la Reproducción.

Correo electrónico: aja@xanum.uam.mx

UAM-Iztapalapa

\section{Dra. Yolanda Cruz Gómez}

Centro Tlaxcala de Biología de la Conducta

Correo electrónico: cruzgomezy@yahoo.com.mx

UAT 
Este trabajo se realizó en la Universidad Autónoma Metropolitana, Unidad Iztapalapa. Se desarrolló en los Laboratorios de: Neurobiología Tisular (S-336) y Biología de la Reproducción Animal Asistida (S-234) del Departamento de Biología de la Reproducción.

Este proyecto contó parcialmente con el financiamiento de los laboratorios antes mencionados de la Universidad Autónoma Metropolitana, Unidad Iztapalapa y con la beca CONACyT Número: 620409.

"El programa de la Maestría en Biología de la Reproducción Animal de la Universidad Autónoma Metropolitana está incluido en el Programa Nacional de Posgrado de Excelencia del CONACyT (PNPC) Registro 003797". 
Los miembros del jurado designados por la División de Ciencias Biológicas y de la Salud, Universidad Autónoma Metropolitana Unidad Iztapalapa, abajo firmantes, aprobaron la tesis titulada: "Análisis morfológico del epididimo y determinación espermática durante la postsaciedad sexual de la rata" con fecha 26 de mayo del 2017.

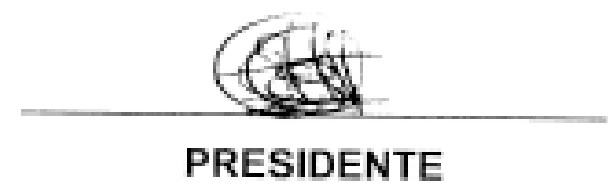

Dra. Edith Arenas Ríos

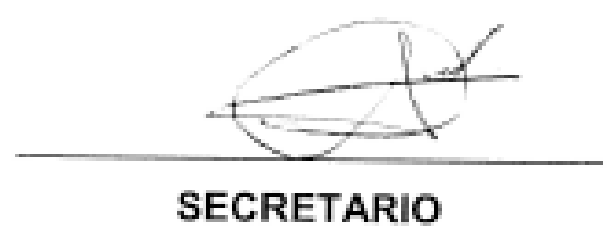

Dr. José Luis Tlachi López

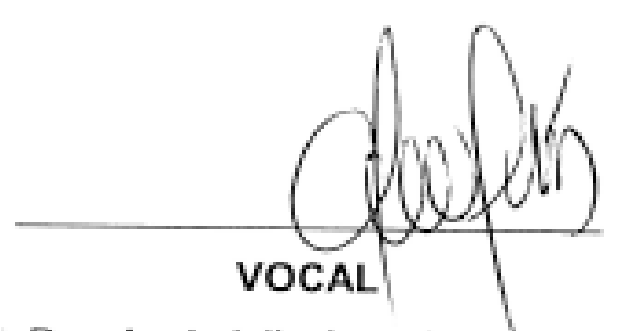

Dra. Anabel Jiménez Angulano

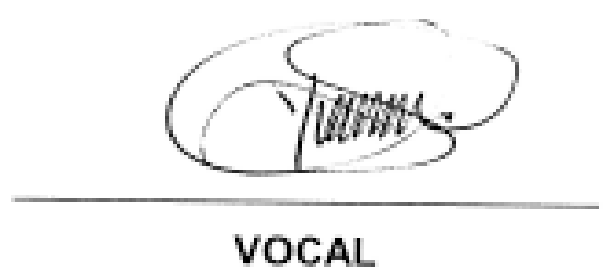

Dra. Yolanda Cruz Gómez 


\section{DEDICATORIAS}

\section{A mis padres}

Por el apoyo y consejos constantes que me han brindado, los valores que me han inculcado durante el transcurso de mi vida por los cuales las decisiones que he tomado y me han llevado a concluir esta etapa e ir pensando en la siguiente.

\section{A mis hermanos}

Por los momentos que hemos pasado, los consejos y el apoyo incondicional que me han brindado.

\section{A mis amigos}

Por estar en momentos alegres y difíciles durante el tiempo que nos conocimos. $Y$ por brindarme su apoyo incondicional. 


\section{AGRADECIMIENTOS}

A la Universidad Autónoma Metropolitana por abrirme las puertas desde la Licenciatura hasta esta etapa del posgrado.

Al Dr. Mario García Lorenzana por abrirme las puertas del laboratorio desde el servicio social hasta este momento y por todo el aprendizaje que me ha dado. $Y$ sobre todo por la confianza que depositó en mí desde que nos conocimos.

A la Dra. Rosa Angélica Lucio Lucio por confiar en mí sin conocerme con anterioridad al posgrado, los consejos que me dio académicamente y por batallar conmigo para que aprendiera a utilizar los términos correctos para este nivel.

Muy en especial a la Dra. Edith Arenas Ríos por permitir que entrara a su laboratorio y sobre todo por la constancia y el aprendizaje que he adquirido de ella. Sin dejar a un lado la confianza que me brindó académicamente y la amistad en el ámbito personal.

Al M. en C. Matías Martínez Coronel que a pesar de las altas y bajas que hemos tenido, prevalece la amistad que me ofreció y sobre todo el conocimiento que adquirí de él a lo largo del tiempo que lo llevo conociendo.

A la Dra. Tarrago por confiar en mí, darme consejos y prestarme ayuda en varios momentos desde que llegue al laboratorio de Neurobiología Tisular.

A los Dres. Humberto y Edmundo por abrirme las puertas de su laboratorio y aceptarme de colada, aunque no perteneciera a su grupo de trabajo.

A las Dras. Anabel Jiménez Anguiano y Yolanda Cruz Gómez por ser mis sinodales y dedicar su tiempo para contribuir en el mejoramiento de esta tesis. 
Al Dr. Juan Rivera por la amistad ofrecida.

A Tlachi y a Vero, que desde que llegaron al laboratorio me brindaron apoyo, consejos y su amistad.

A todos mis compañeros de trabajo, ya que de ellos he adquirido conocimientos y pasado buenos momentos. En especial a Lorena Ruiz Valderrama por la amistad que me brindó y por todo su apoyo en este proyecto.

A Jessica Tellez, Iván Vargas e Iván Bahena por compartir momentos y darme consejos en todo momento.

Y sobre todo a mis amigas de toda la vida Lesly y Carmina que a pesar de la distancia y el poco tiempo me han apoyado de diferente manera en esta etapa.

A Mireya por su apoyo incondicional y amistad. $Y$ por los proyectos que hay en puerta.

A Laura, Daisy y José por toda la amistad y el apoyo ofrecido desde que nos conocemos hasta ahora. Y por estar en momentos complicados al igual que felices.

Y finalmente, pero no menos importantes a todas esas personas que han pasado por las diferentes etapas de mi vida, que directa o indirectamente tuvieron que ver con el desarrollo de este proyecto, ya que sin su apoyo este no se hubiera completado. $Y$ que a pesar de que algunas han tomado diferentes caminos, otras permanecen en recuerdos/corazón y otras están aquí conmigo, me he llevado mucho aprendizaje de ellos, les agradezco haberse cruzado en mi vida y les deseo lo mejor. 
"Las funciones superiores del cerebro -la memoria y la facultad de razonar- se explican, para Hyden, por la forma particular de las moléculas de proteína que corresponde a cada clase de excitación. Cada neurona del cerebro contiene millones de moléculas de ácidos ribonucleicos diferentes, que se distinguen por la disposición de sus elementos constituyentes simples. Cada molécula particular de ácido ribonucleico (RNA) corresponde a una proteína bien definida, a la manera como una llave se adapta exactamente a una cerradura. Los ácidos nucleicos dictan a la neurona la forma de la molécula de proteína que va a formar. Estas moléculas son, según los investigadores suecos, la traducción química de los pensamientos.

La memoria correspondería, pues, a la ordenación de las moléculas de ácidos nucleicos en el cerebro, que desempeñan el papel de las tarjetas perforadas en las computadoras modernas. Por ejemplo, el impulso que corresponde a la nota "mi" captada por el oído se desliza rápidamente de una neurona a otra hasta alcanzar a todas aquellas que contienen las moléculas de ácido RNA correspondiente a esta excitación particular. Las células fabrican de inmediato moléculas de la proteína correspondiente regida por este ácido, y realizamos la audición de dicha nota.

La riqueza, la variedad del pensamiento se explican por el hecho de que un cerebro medio contiene unos diez mil millones de neuronas, cada una de las cuales encierra varios millones de moléculas de distintos ácidos nucleicos, el número de combinaciones posibles es astronómico. Esta teoría tiene, por otra parte, la ventaja de explicar por qué en el cerebro no se han podido describir zonas netamente definidas y particulares de cada una de las funciones cerebrales superiores; como cada neurona dispone de varios ácidos nucleicos, puede participar en procesos mentales diferentes, y evocar pensamientos y recuerdos diversos." 
“Nada es peor que no tener principios cuando ya está próximo el final."

"Si la palabra es acción entonces ven a contarme el amor, que quiero hacer contigo todo lo que la poesía aún no ha escrito" 


\section{ÍNDICE}

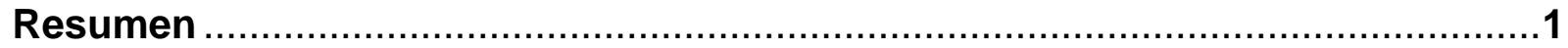

Abstract

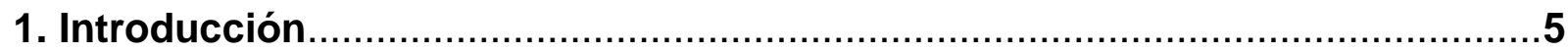

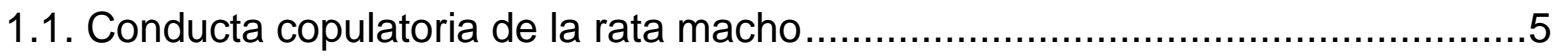

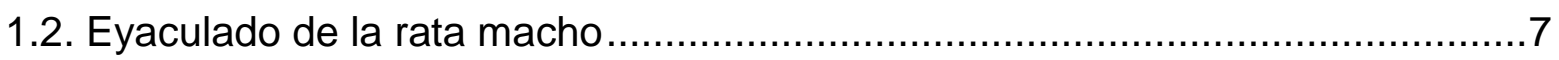

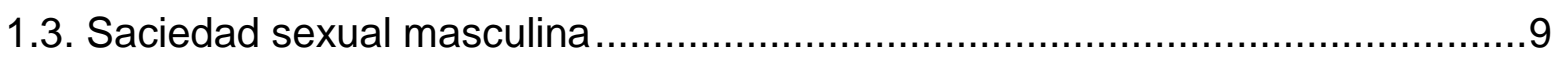

1.4. Parámetros seminales (postsaciedad sexual) .............................................

1.5. Características morfológicas del epidídimo ....................................................10

1.6. Características morfológicas del espermatozoide ........................................14

1.7. Papel de los andrógenos en el epidídimo ….............................................15

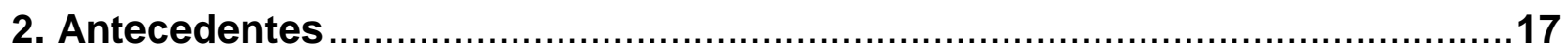

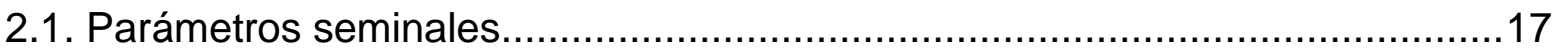

2.2. Restablecimiento de la conducta copulatoria ............................................. 18

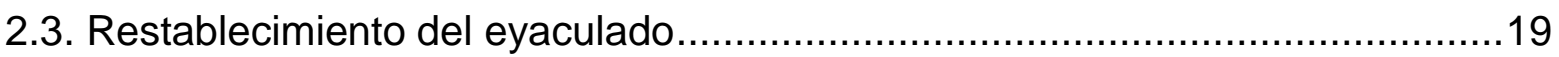

2.4. Hallazgos histológicos en testículo y epidídimo posterior a la saciedad sexual

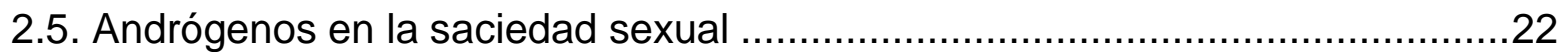

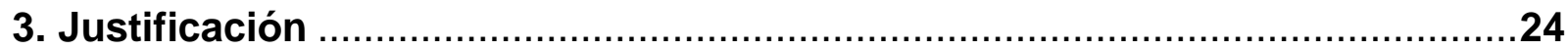

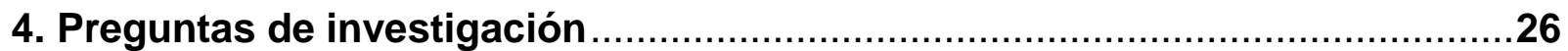

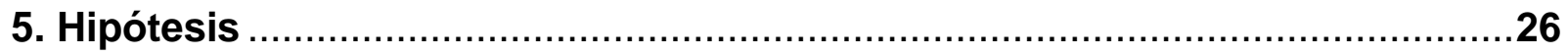

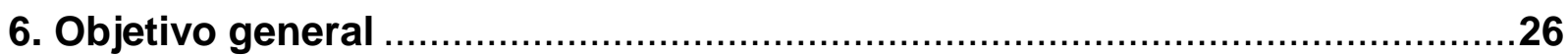

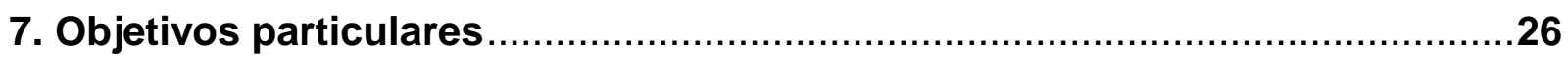

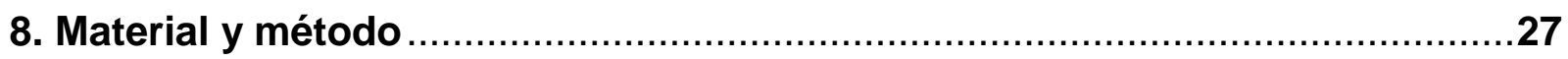




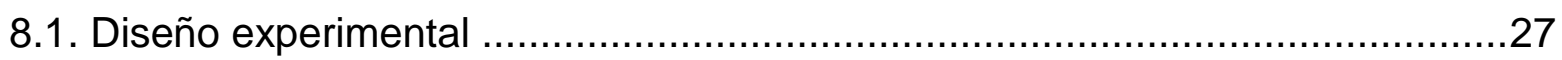

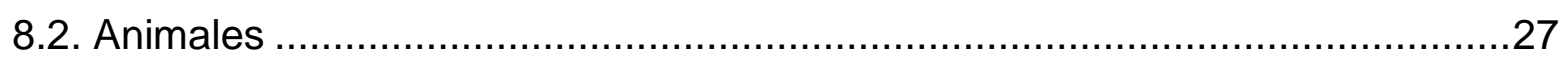

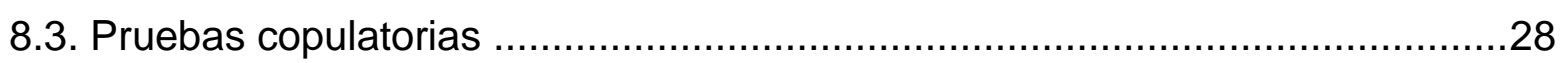

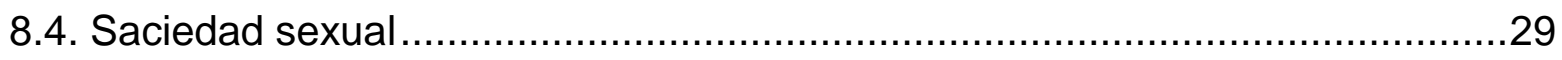

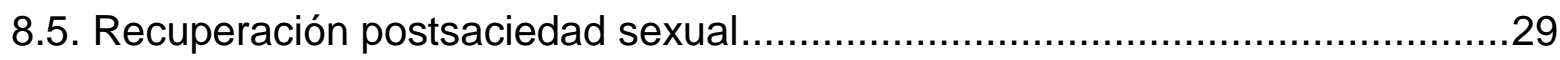

8.6. Obtención de muestras del epidídimo .......................................................29

8.7. Determinación de parámetros espermáticos del epidídimo...............................30

8.8. Técnica histológica y análisis morfométrico del epidídimo ..............................31

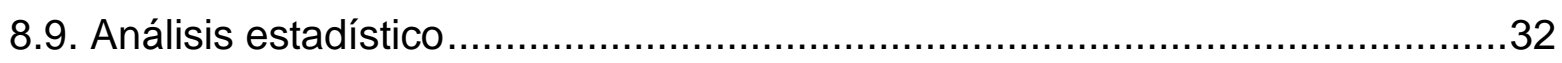

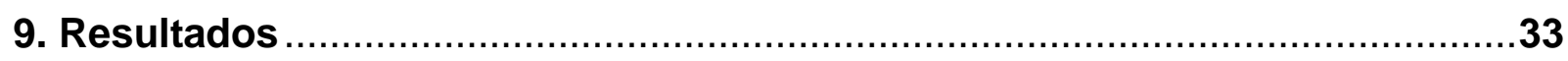

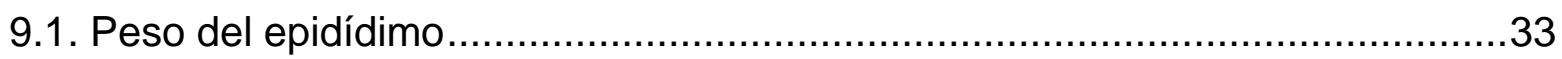

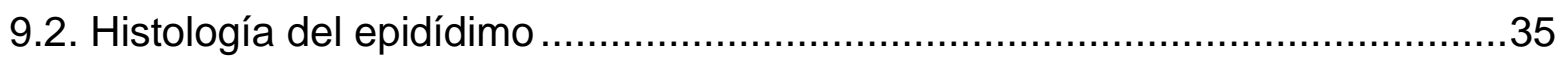

9.2.1. Análisis cualitativo del epidídimo .......................................................35

9.2.2. Análisis cuantitativo del epidídimo ……….......................................... 40

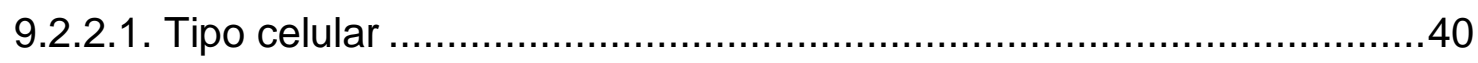

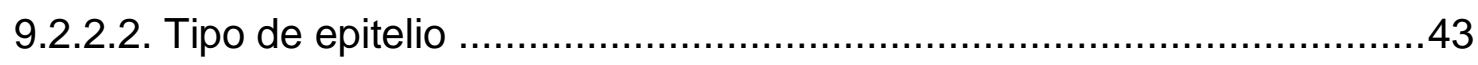

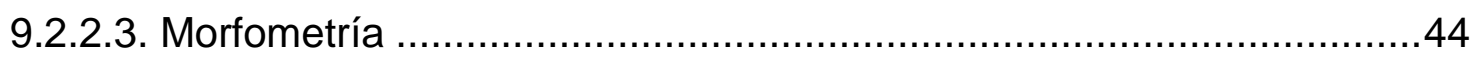

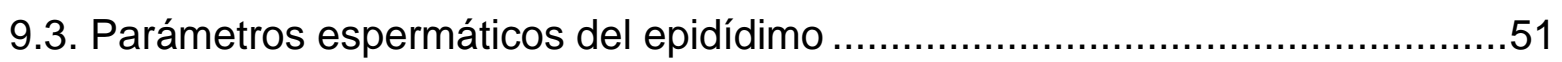

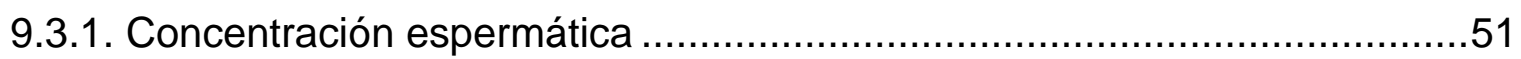

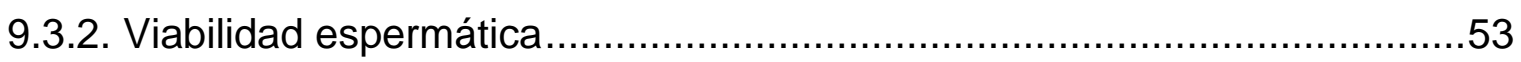

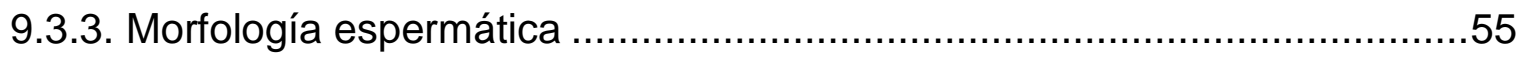

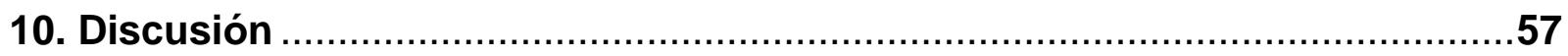

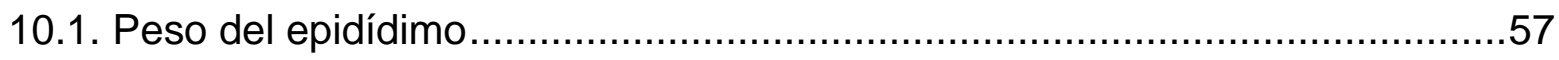

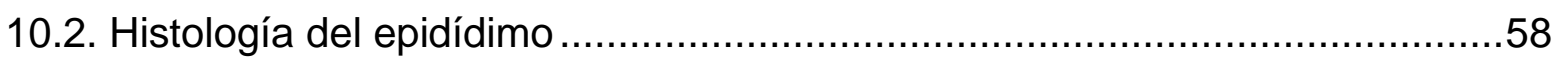




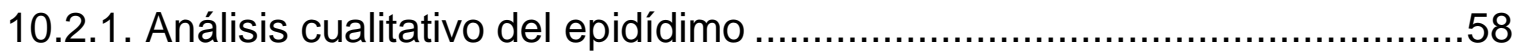

10.2.2. Análisis cuantitativo del epidídimo ....................................................59

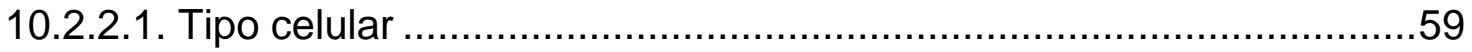

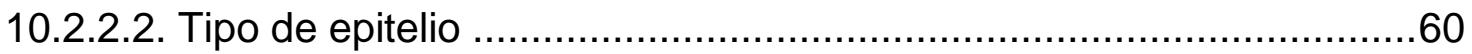

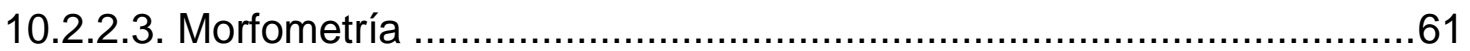

10.3. Parámetros espermáticos del epidídimo …................................................62

10.3.1. Concentración, viabilidad y morfología espermática...............................62

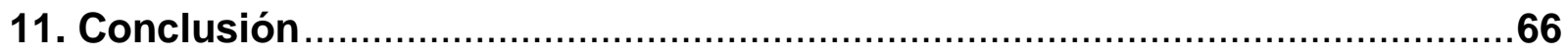

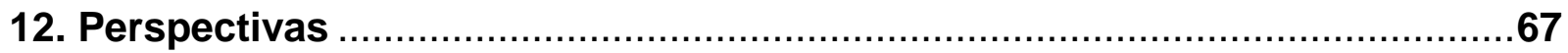

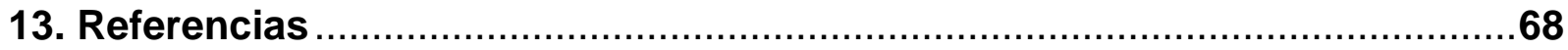




\section{ÍNDICE DE ABREVIATURAS}

cap

cor

cau

BHE

H-E

$\mathrm{T}$

$\mathrm{LH}$

$\mathrm{FSH}$

RA

RE $\alpha$

ADN

ARN

APOm

$\mathrm{VMH}$

BST

SL

$\mathrm{AMe}$

AAs

DB

DA

$\mathrm{AE}$

ALLE

ALT
Caput

Corpus

Cauda

Barrera hematoepididimaria

Hematoxilina y Eosina

Testosterona

Hormona luteinizante

Hormona foliculoestimulante

Receptores a andrógenos

Receptores a estrógenos-alfa

Ácido desoxirribonucleico

Ácido ribonucleico

Área preóptica media

Núcleo ventromedial hipotalámico

Lecho de la estría terminalis

Septo lateral

Amígdala medial

Área del aglomerado de espermatozoides

Dominio basal

Dominio apical

Área del epitelio

Área luminal libre de espermatozoides

Área luminal total 


\section{ANEXOS}

\section{Pruebas de conducta: Sustancias}

- Hormonas: 17-Beta-estradiol-3-benzoato (E2)

Aceite de oliva $50 \mathrm{ml}$

$\mathrm{E}_{2}$ $0.005 \mathrm{~g}$

- Hormonas: Progesterona $\left(\mathrm{P}_{4}\right)$

Aceite de oliva $.50 \mathrm{ml}$

P4

2. Histología: Reactivos, soluciones y procesamientos

- Fijador Bouin Dubosq (Bouin Alcoholico)

Alcohol 80은

Formaldehido en solución

Ácido Pícrico

Ácido Acético glacial

Se disuelve el ácido pícrico en alcohol $80^{\circ}$, se filtra y se agrega el formaldehido, posteriormente se le agrega el ácido acético glacial. 
- Procesamientos: Lavados (grados Gay Lussac)

Alcohol $70^{\circ}$

14 lavados de $30 \mathrm{~min} \mathrm{c} / \mathrm{u}$

- Procesamiento: Deshidratación (con diferentes grados Gay Lussac)

Alcohol $80^{\circ}$

$1 \mathrm{~h}$

Alcohol 96은

$1 \mathrm{~h}$

Alcohol 96은

$1 \mathrm{~h}$

Alcohol 96은

$1 \mathrm{~h}$

Alcohol 100

$1 \mathrm{~h}$

Alcohol $100^{\circ}$

$1 \mathrm{~h}$

Alcohol 100은

$1 \mathrm{~h}$

- Procesamiento: Aclaración

Alcohol Xileno

$50 \min$

Xileno $50 \mathrm{~min}$

Xileno $50 \mathrm{~min}$

- Procesamiento: Infiltrado

Paraplas-xtra $1 \mathrm{~h}$

Paraplas-xtra $1 \mathrm{~h}$ 
Todo el procesamiento, desde la deshidratación hasta el infiltrado, se realizó con el procesador de tejidos (Leica, TP 1020) y utilizando el programa 4.

- Procesamiento: Inclusión

Se realizó cuidando que todo el tiempo el paraplas-xtra y el epidídimo permanecieran a una temperatura de 60 centígrados utilizando escuadras de Leukart.

- Cortes y premontaje

Se utilizaron portaobjetos esmerilados $(25 \times 75 \mathrm{~mm})$ de la marca Madesa. Se empezó a premontar en el momento que el tejido empezó a salir completo. Y se obtuvieron 7 laminillas con 4 cortes cada una (en total 28 cortes longitudinales seriados de 5 micrómetros de espesor) (caput $=162.22 \pm 46.60$, corpus $=$ $244.44 \pm 135.51$ y cauda $=146.66 \pm 39.71$ cortes $)$.

- Reactivos, soluciones de la tinción y montaje Hematoxilina de Harris

Hematoxilia (Solución Papanicolaou)

Ácido Acético

Se filtró la Hematoxilina y después se le agregó el ácido acético. 


\section{Solución Madre Eosina Amarillenta}

Eosina Amarillenta al $1 \%$

Alcohol 96은

Se mezclaron los dos reactivos y se obtuvo la solución madre.

Eosina Solución de trabajo

Eosina Solución Madre

Alcohol 80은

Ácido Acético

Se mezclaron la Eosina y el alcohol $80^{\circ}$ y se le agregó el ácido acético

Se utilizó la técnica de tinción Hematoxilina - Eosina (HE):

Hidratación:

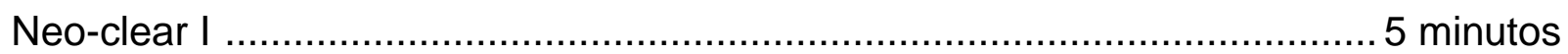

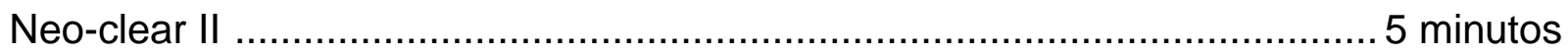

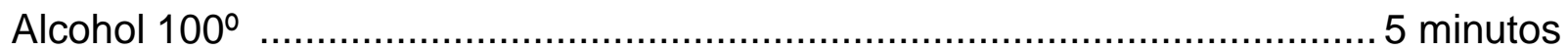

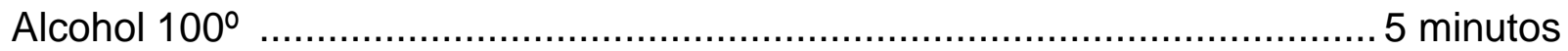

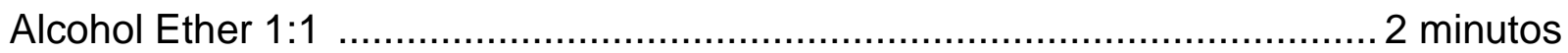

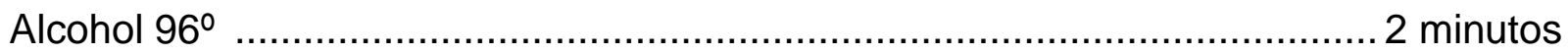

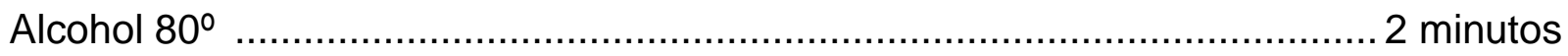


Alcohol $60^{\circ}$ 2 minutos

Agua destilada lavados hasta que dejen de verse llorosos

Hematoxilina 7 minutos

Agua de la llave lavados

Alcohol ácido 1 lavado rápido

Agua destilada lavados

Solución de Scott 8 minutos

Agua destilada lavados

Eosina $2: 30$ minutos

Agua destilada lavados

Deshidratación:

Alcohol 96ㅇ I lavados

Alcohol 96 II lavados

Alcohol 100ㅇ lavados

Alcohol $100^{\circ}$ II lavados

Alcohol Xileno. lavados

Xileno I lavados

Xileno II lavados

El montaje se realizó colocando unas gotas de Entellan en las laminillas teñidas y situando un cubre objetos sobre el tejido, cuidando que no quedaran burbujas. 


\section{Determinación espermática: Reactivos y soluciones}

- Extracción de espermatozoides: Ringer a un pH de 7.2

$\mathrm{NaCl} 95 \mathrm{mM}$

$\mathrm{KCl} 5 \mathrm{mM}$

$\mathrm{KH}_{2} \mathrm{PO}_{4} 1.1 \mathrm{mM}$

$\mathrm{CaCl} 2-2 \mathrm{H}_{2} \mathrm{O} 1.7 \mathrm{mM}$

Por ser animales con postsaciedad sexual, se utilizaron $500 \mu \mathrm{l}$ para los días 016 y $1000 \mu$ l los del día 20-28 y controles.

- Viabilidad espermatica

Eosina-Nigrosina

Eosina $Y 1 \%$ en agua destilada

Nigrosina $10 \%$ en agua destilada

Cloruro de sodio

Previamente se calentó el agua destilada, se disolvió la Eosina $\mathrm{Y}$ junto con el cloruro de sodio y se le agregó la Nigrosina. Se hirvió la suspensión, se le permitió enfriarse a temperatura ambiente yse filtró.

- Concentración espermatica

Para obtener la concentración espermática se determinó la densidad y posteriormente la dilución. Considerando el siguiente cuadro: 


\begin{tabular}{cccccc}
\hline $\begin{array}{c}\text { Espermatozoides } \\
\text { en 400X }\end{array}$ & $\begin{array}{c}\text { Espermatozoides } \\
\text { en 200X }\end{array}$ & $\begin{array}{c}\text { Dilución } \\
\text { requerida }\end{array}$ & Semen $(\mu \mathrm{l})$ & Fijador $(\mu \mathrm{l})$ & Fórmula utilizada \\
\hline$>101$ & $>404$ & $1: 20(1+19)$ & 50 & 950 & $\mathrm{C}=(\mathrm{N} / \mathrm{n}) \times(1 / 20) \times 20$ \\
$16-100$ & $64-400$ & $1: 5(1+4)$ & 50 & 200 & $\mathrm{C}=(\mathrm{N} / \mathrm{n}) \times(1 / 20) \times 5$ \\
$2-15$ & $8-60$ & $1: 2(1+1)$ & 50 & 50 & $\mathrm{C}=(\mathrm{N} / \mathrm{n}) \times(1 / 20) \times 2$ \\
$<2$ & $<2$ & $1: 2(1+1)$ & 50 & 50 & $\mathrm{C}=(\mathrm{N} / 1800) \times 2$ \\
\hline
\end{tabular}

Tabla. Diluciones utilizadas (modificado del Manual WHO, 2010).

Una vez obtenida la dilución, se colocaron $10 \mu \mathrm{l}$ a cada lado de la cámara de Neubauer y se observó al microscopio de campo claro a 40X. La lectura se hizo de la siguiente manera:

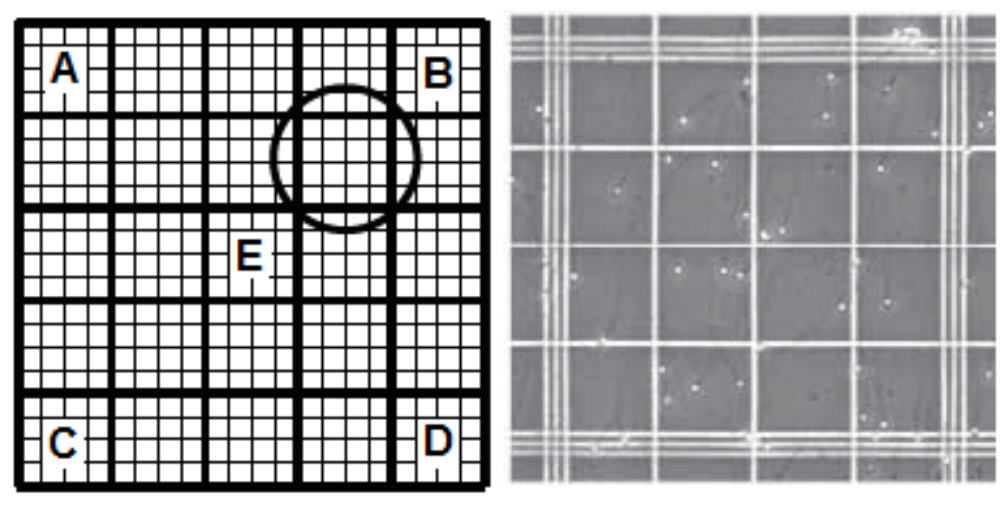

Fig. Cámara de Neubauer (modificado del manual WHO, 2010).

Del cuadro E, se contaron los espermatozoides que se encontraban en los cinco cuadrantes (de cada esquina y el central). Lo anterior se hizo de cada lado de la cámara.

Para obtener el resultado, se sumaron las cantidades obtenidas de ambos cuadros de cada lado de la cámara, luego se dividió entre dos, el resultado de estos se divide entre el factor de conversión. Finalmente el resultado se expresa en millones por mililitro. 
- Morfología espermática

Paraformaldehido (PAF) $1 \%$

PAF al $1 \%$

Buffer de fosfatos

Para disolver el PAF, se utilizó un matraz en donde se agrego la solución amortiguadora (buffer de fosfatos) y se vacío poco a poco el paraformaldehido, lo anterior estuvo en constante agitación hasta que se disolvió completamente. Esta solución se mantuvo a $60 \stackrel{\circ}{\mathrm{C}}$ a baño Maria.

\section{Tinción de Papanicolau}

Se obtuvo mediante la técnica de Papanicolau modificado del manual (WHO, 2010), la tinción fue la siguiente:

Alcohol $80^{\circ}$ 30 segundos

Alcohol $50^{\circ}$ 30 segundos

Agua destilada 30 segundos

Harris hematoxilina (Papanicolau) 4 minutos

Agua destilada 30 segundos

Alcohol ácido 4 inmersiones de 1 segundo

Agua de la llave fría 5 minutos

Alcohol 50은 30 segundos

Alcohol 80은 30 segundos 
Montaje:

Alcohol Xileno 1 minuto

Xileno I 1 minuto

El montaje se realizó colocando unas gotas de Entellan en la laminillas teñidas y situando un cubre objetos sobre el porta objetos, cuidando que no quedaran burbujas. 


\section{RESUMEN}

La saciedad sexual es la inhibición de la cópula, debido al apareamiento repetido y se reconoce cuando el macho no presenta más patrones motores de monta ni de intromisión durante 30 minutos después del último patrón eyaculatorio. Tras la saciedad sexual, la conducta se restituye gradualmente y el eyaculado también aunque más tardíamente. La concentración espermática que empieza a recuperarse a los 15 días postsaciedad sexual, depende de las funciones epididimarias. El epidídimo es un órgano andrógeno-dependiente; es compacto microtubular que presenta células principales, basales, apicales, estrechas, claras y de tipo halo. Por lo tanto, como primer acercamiento y lo que constituye el objetivo del presente trabajo fue analizar la morfología epididimaria y la determinación espermática que permitan explicar la recuperación de la cuenta espermática, durante la postsaciedad sexual de la rata. En este estudio, se ocuparon ratas macho expertos de la cepa Wistar, los cuales se colocaron en pruebas copulatorias hasta la saciedad sexual. Se ocuparon un total de nueve grupos con una $n=3$ por grupo. Estos grupos se dejaron recuperar 4, 8, 12, 16, 20, 24 y 28 días postsaciedad sexual, a parte se tuvo un grupo inmediato a la saciedad sexual y un grupo control con una serie eyaculatoria. Posterior a la recuperación, se obtuvieron los epidídimos y se regionalizaron en caput, corpus y cauda. Un epidídimo se utilizo para los parámetros espermáticos: viabilidad, concentración y morfología espermática; el otro epidídimo para analizar la morfología mediante la técnica histológica. En el análisis estadístico se utilizo $U$ Mann-Whitney para la morfometría y tipo celular, y un ANOVA seguida de TukeyKramer para el tipo epitelio y los parámetros espermáticos. Considerándolos significativos con un valor de $\mathrm{P}<0.05$. Encontramos que posterior a la saciedad sexual, los pesos presentan diferencias significativas $(P<0.05)$, en el peso total, caput y cauda del epidídimo incremento, mientras que en el corpus disminuyó. En cuanto a la citología celular, se observaron cambios en las tonalidades basófilas y acidófilas, encontrando más células inactivas. Esto se relaciona con el conteo de los tipos celulares: se encontraron diferencias significativas $(P<0.05)$, en donde disminuyó el 
número de células principales, basales y halo. El conteo en el conducto epididimario de los diferentes tipos de epitelio fue: del epitelio simple cilíndrico hubo diferencias significativas $(\mathrm{P}<0.05)$ disminuyendo en los días 8 en caput y 12 en cauda. La morfometría mostró diferencias $(\mathrm{P}<0.05)$ en las áreas medidas; siendo la altura la que mayor diferencia presentó siendo caput y cauda las más afectadas. Respecto a los parámetros espermáticos, presentaron diferencias significativas $(P<0.05)$ en: concentración los días 0-8 y 16, viabilidad y morfología estuvieron reducidos en los días 0 al 16. En suma, el peso del epidídimo se debió a una posible hiperplasia o bien a que la barrera hematoepididimaria se dañó. En cuanto a la citología celular y el mayor número de células inactivas que se encontraron podría deberse a la disminución de testosterona local. A esto se añade la reducción del conteo celular (principales, basales y halo). Las regiones en donde se observaron cambios en la morfometría fueron caput y cauda, quizás se deba a que el testículo mantiene la producción de espermatozoides que continúan su recorrido por el epidídimo por lo que debe mantener su actividad. Los valores de los parámetros espermáticos epididimarios podrían deberse tanto a la disminución de andrógenos locales como también a que los estrógenos no se encuentren en niveles normales. En conclusión, encontramos cambios morfológicos en el periodo postsaciedad sexual, lo más acentuados, fueron la disminución en la altura del epitelio, los tipos celulares y los valores de los parámetros espermáticos. Siendo en la concentración espermática la más afectada, viéndose recuperada a partir del día 20 en la cauda del epidídimo. Será necesario indagar sobre el papel de los andrógenos y estrógenos durante la saciedad sexual y el restablecimiento del eyaculado. 


\section{ABSTRACT}

Sexual satiety is the inhibition of intercourse due to repeated mating and is recognized when the male has no more motor patterns or intrusions for 30 minutes after the last ejaculatory pattern. After the sexual satiety, the behavior is gradually restored and the ejaculate also, although later. The sperm concentration that begins to recover at 15 days after the sexual satiety, depends on epididymal functions. The epididymis is an androgen-dependent organ; is compact microtubular that presents main, basal, apical, narrow, clear and halo type cells. Therefore, as a first approach and what constitutes the objective of the present work was to analyze the epididymal morphology and sperm determination that allow to explain the recovery of the sperm count, during sexual post-sex of the rat. In this study, expert male rats of the Wistar strain were placed, which were placed in copulatory tests until sexual satiety. A total of nine groups were occupied with $n=3$ per group. These groups were allowed to recover $4,8,12,16,20,24$ and 28 days after sex, apart from having an immediate sexual satiety group and a control group with an ejaculatory series. After the recovery, the epididymides were obtained and regionalized in caput, corpus and tail. An epididymis was used for sperm parameters: viability, concentration and sperm morphology; The other epididymis to analyze the morphology through the histological technique. In the statistical analysis $U$ Mann-Whitney was used for morphometry and cell type, and ANOVA followed by Tukey-Kramer for the type epithelium and sperm parameters. Considering them significant with a value of $P<0.05$. We found that after the sexual satiety, the weights presented significant differences $(P<0.05)$, in the total weight, caput and tail of the epididymis increase, while in the corpus decreased. As for the cell cytology, changes in basophilic and acidophilic tonalities were observed, finding more cells inactive. This was related to the cell types counting: significant differences were found $(\mathrm{P}<0.05)$, where the number of main, basal and halo cells decreased. The count in the epididymal duct of the different types of epithelium was: from the simple cylindrical epithelium there were significant differences $(P<0.05)$ decreasing in days 8 in caput and 12 in tail. Morphometry showed differences 
$(P<0.05)$ in the measured areas; Being the height that the greater difference was presented caput and tail the most affected. Regarding the sperm parameters, they presented significant differences $(P<0.05)$ in: concentration days $0-8$ and 16 , viability and morphology were reduced on days 0 to 16 . In sum, the weight of the epididymis was due to possible hyperplasia Or to which the hematoepididimary barrier was damaged. As for the cell cytology and the greater number of inactive cells that were found could be due to the decrease of local testosterone. To this is added the reduction of the cellular count (main, basal and halo). The regions where changes in morphometry were observed were caput and tail, perhaps because the testis maintains the production of spermatozoa that continue to travel through the epididymis so it must maintain its activity. The values of the epididymal sperm parameters could be due to the decrease of local androgens as well as to that the estrogens are not in normal levels. In conclusion, we found morphological changes in the post-sexual satiety period, the most pronounced being the decrease in epithelial height, cell types and sperm parameters. Being in the spermatic concentration the most affected, being recovered from day 20 in the tail of the epididymis. It will be necessary to inquire about the role of androgens and estrogens during sexual satiety and the reestablishment of the ejaculate. 


\section{INTRODUCCIÓN.}

La saciedad sexual masculina es la inhibición de la conducta de apareamiento debida a eyaculaciones sucesivas (Larsson, 1956). Tal inhibición no se debe a la fatiga física del individuo, sino a la desmotivación sexual por la pareja (Beach y Jordan, 1956). La saciedad sexual empezó a estudiarse desde el punto de vista conductual (Larsson, 1956; Beach y Jordan, 1956), después desde la perspectiva neuroendocrinológica y farmacológica (Rodríguez-Manzo y Fernández-Guasti, 1994; Fernández-Guasti y Rodríguez-Manzo, 2003) y más recientemente, se ha estudiado la saciedad sexual con un matiz ecofisiológico (Tlachi-López y cols., 2012; Lucio y cols., 2014). Sin embargo, no se ha explorado el efecto sobre el epidídimo debido a la saciedad sexual.

Antes de continuar con la saciedad sexual es pertinente describir la conducta sexual masculina (Fig. 1). Tal conducta fue descrita amplia y detalladamente para la rata (Rattus norvegicus; Larsson, 1956). Es así que la rata de laboratorio ha sido el animal más socorrido en los estudios conductuales y sobre la fisiología masculina.

\subsection{Conducta copulatoria de la rata macho}

\section{Patrones motores y respuestas genitales durante la conducta copulatoria}
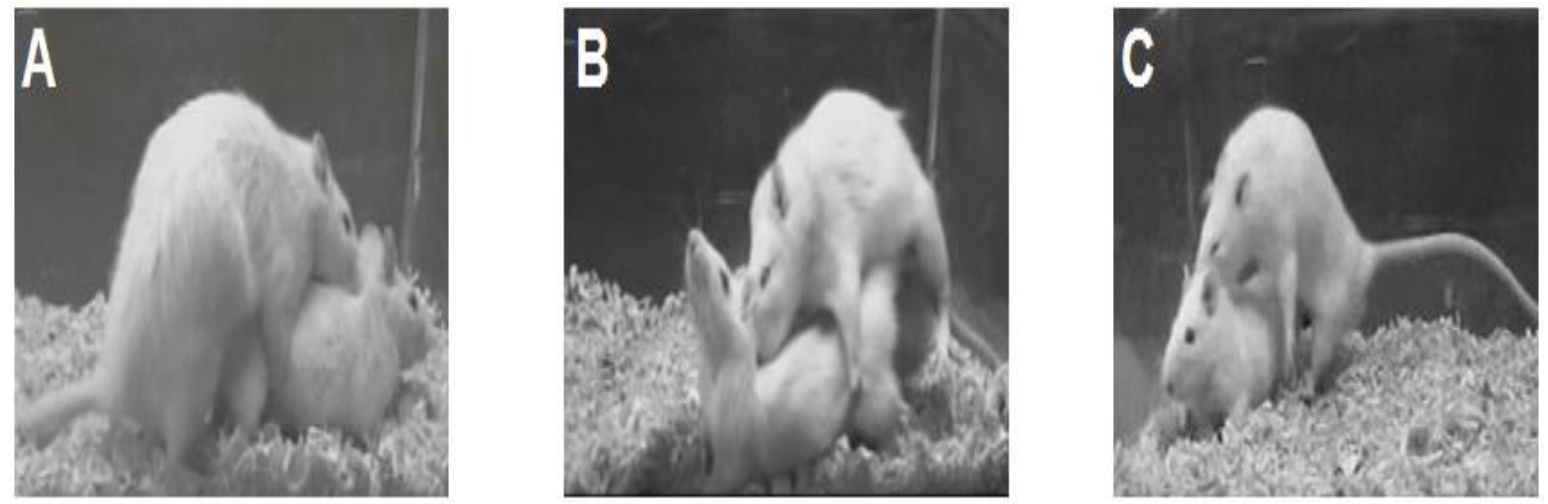

Figura 1. Patrones motores de rata Wistar. A) monta, B) intromisión, C) eyaculación (Lucio y Tlachi-López, 2008). 
La rata macho muestra patrones motores estereotipados durante la cópula, identificados como: monta, intromisión y eyaculación (Fig. 1). Durante la monta, el macho con sus extremidades delanteras palpa los flancos de la hembra y ejecuta movimientos pélvicos hacia adelante y hacia atrás sobre la grupa femenina (Fig. $1 \mathrm{~A}$ ). La intromisión inicia como la monta, se distingue de ella porque el último de los movimientos pélvicos es profundo que se asocia con la inserción del pene en la vagina, seguido inmediatamente de la desmonta brusca hacia atrás (Fig. 1 B) (Pollak y Sachs, 1976). De este modo, cuando se observa este patrón conductual se asume que la inserción del pene ocurre y no se verifica (Sachs y Meisel, 1988). Sin embargo, Pollak y Sachs, (1976) mencionan que el macho no logra la inserción del pene, pero muestra el patrón motor de intromisión. Por tal razón, debe llamarse patrón de intromisión cuando no se constata la inserción del pene en la vagina; y debe llamarse intromisión cuando se utiliza algún método que verifica la inserción del pene (Sachs y Meisel, 1988).

Después de varias montas e intromisiones ocurre la eyaculación, caracterizada por el movimiento pélvico que es más profundo y sostenido que el de la intromisión (Fig. 1 C). Cuando se observa al macho realizar el patrón de eyaculación, se asume que expele fluido seminal (espermatozoides y plasma seminal) quedando depositado en la vagina. Después el macho levanta su tronco, al mismo tiempo extiende lateralmente sus extremidades anteriores y se desmonta de manera lenta. Posteriormente, se acicala el pene y la región perineal (Larsson, 1956). De igual modo, debe llamarse patrón de eyaculación cuando no se constata la expulsión de semen; y debe llamarse eyaculación cuando se utiliza algún método que verifica el depósito de semen en la vagina (Sachs y Meisel, 1988; Hull y cols., 2006). Técnicamente, la eyaculación se refiere a la expulsión de semen por el meato uretral desde la uretra prostática. Las contracciones rítmicas de los músculos esqueléticos y perineales: isquiocavernoso, aumentan la presión cavernosa y la contracción del músculo bulbosponjoso, aumenta la presión en el glande, así como la contribución de factores vasculares y de los músculos estriados del pene, 
acompañan a la eyaculación (Hull y Rodríguez-Manzo, 2009). Después de la eyaculación, el macho presenta el intervalo post-eyaculatorio que comprende el tiempo que transcurre entre la eyaculación hasta que se presenta la monta o intromisión de la siguiente serie eyaculatoria; este intervalo post-eyaculatorio tiene una duración de 5-8 minutos e incrementa después de eyaculaciones sucesivas (Lucio y Tlachi-López, 2008; Hull y Rodríguez-Manzo, 2009).

Así, los patrones motores copulatorios de monta e intromisión se acompañan de respuestas genitales. El patrón de intromisión se acompaña de la inserción del pene; el de eyaculación, de la expulsión seminal. En la rata macho, puede realizarse la observación del pene colocando un espejo a $45^{\circ}$ debajo de la arena de observación, aunque la duración de la erección es de escasos milisegundos. La expulsión seminal es más fácil de corroborar al observar el tapón seminal mediante métodos como el contraste radiopaco (Wallach y Hart, 1983) o directamente extrayéndolo quirúrgicamente de la vagina (Austin y Dewsbury, 1986; Tlachi-López y cols., 2012). El tapón seminal también puede ser retirado de la vagina cuando otro macho realiza 3-4 intromisiones o incluso por el mismo animal que lo depositó una vez concluido el intervalo post-eyaculatorio (McClintock y cols., 1982; Lucio y cols., 1994; Tlachi-López y cols., 2012; Lucio y cols., 2014).

\subsection{Eyaculación de la rata macho}

Cuando se habla de eyaculación, se refiere a la expulsión de semen por el meato uretral y consiste en dos fases: emisión seminal y expulsión seminal, que involucran eventos autónomos y somáticos (Lucio y Tlachi-López, 2008; Hull y RodríguezManzo, 2009).

La emisión seminal implica el cierre de los esfínteres del cuello de la vejiga urinaria y se contraen la próstata, los conductos deferentes y las glándulas coagulantes (Hull y Rodríguez-Manzo, 2009) y consiste en el transporte y reunión de espermatozoides con los fluidos suministrados por las glándulas sexuales accesorias en la uretra proximal. La expulsión seminal implica la contracción rítmica de la 
estructura perinea y pélvica, y es la salida del semen (espermatozoides y secreciones glandulares) por el meato uretral, debido a contracciones rítmicas de la musculatura lisa de la uretra y de la musculatura estriada del periné y pélvicos que incluyen al isquiocavernoso, bulboesponjoso (Lucio y Tlachi-López, 2008; Hull y Rodríguez-Manzo, 2009).

\section{Particularidades del eyaculado de la rata macho}

Durante la emisión seminal, los espermatozoides son seguidos por las secreciones de las glándulas sexuales accesorias y constituyen el eyaculado. Gran parte del eyaculado, constituido por las secreciones glandulares, se endurecen formando el tapón seminal (Blandau, 1945), que al adherirse fuertemente a las paredes vaginales y al cérvix favorecen el transporte espermático transcervical. Dicho transporte ocurre durante los primeros minutos después de la eyaculación (Matthews y Adler, 1977). intervalo post-eyaculatorio que dura alrededor de 5-10 minutos impide al macho retirar su propio tapón antes de que ocurra el transporte de los espermatozoides que previamente depositó. La remoción del tapón en menos de 6 minutos después de la eyaculación interrumpe el transporte espermático que resulta en una mínima o nula cantidad de espermatozoides (Matthews y Adler, 1977). En condiciones naturales y semi-naturales, las ratas hembra sexualmente receptivas pueden copular con diferentes machos, dado que la especie es gregaria y altamente promiscua (McClintock y Adler, 1978; McClintock y cols., 1982). Por lo tanto, si dos machos eyaculan en la misma hembra puede que el segundo haya retirado el tapón del primero o bien que la hembra contenga en su tracto reproductor los espermatozoides de ambos machos, favoreciendo con ello, la competencia espermática por los óvulos (Parker, 1998). Esta situación parece una ventaja entre individuos, ya que aumenta la diversidad genética de la descendencia. De hecho, en una misma camada, la paternidad puede ser compartida, es decir, más de un macho puede resultar el padre de las crías. 
La evaluación de las características del eyaculado puede ser directa (obtenido directamente del macho) o indirectamente (obteniéndolo del tracto reproductor de una hembra recién apareada). Comúnmente, para la obtención directa de semen se utiliza la electroeyaculación, técnica no estandarizada para la rata macho, además no existen vaginas artificiales para la colecta. Por ello, es que el eyaculado se evalúa por espermatobioscopía indirecta, mediante la aspiración del contenido uterino tras la administración de solución salina (Austin y Dewsbury, 1986; Matthews y Adler, 1977; Carballada y Esponda, 1992) o mediante el vaciamiento del fluido uterino después de su extirpación de los cuernos uterinos (Lucio y Tlachi-López, 2008).

\subsection{Saciedad sexual masculina}

Los machos de varias especies presentan saciedad sexual definida como la inhibición de la conducta copulatoria después del apareamiento repetido (revisión en Phillips-Farfán y Fernández-Guasti, 2009). Es decir, conforme avanzan las series eyaculatorias disminuye el número de intromisiones, así como la latencia de eyaculación (Rodríguez-Manzo y Fernández-Guasti, 1994). El cambio más drástico es el aumento exponencial en la duración de los intervalos post-eyaculatorios (Larsson, 1956; Beach y Jordan, 1956; Rodríguez-Manzo y Fernández-Guasti, 1994). Por lo que se considera que la rata macho está sexualmente saciada cuando no presenta patrones motores de monta ni de intromisión durante 30-90 minutos después de la última eyaculación (Fernández-Guasti y Rodríguez-Manzo, 2003; Tlachi-López y cols., 2012).

\subsection{Parámetros seminales (postsaciedad sexual)}

Los machos sexualmente saciados mantienen en la cauda del epidídimo el $44 \%$ de espermatozoides respecto a la cantidad encontrada en los machos que sólo realizaron una eyaculación (Tlachi-López y cols., 2012). De modo que, los saciados sexualmente tienen espermatozoides para seguir expeliendo. Quizás no los expelen porque sería infructuoso dado que las secreciones de las glándulas accesorias están ausentes. En sucesivas eyaculaciones disminuye el tapón seminal hasta 
desaparecer, esto significa que no hay secreciones de las glándulas sexuales accesorias (Pessah y Kochva, 1975). Si no hay secreciones glandulares no hay plasma seminal y sin éste no tiene sentido expeler solo espermatozoides. El transporte de los espermatozoides desde la cauda hasta la uretra prostática, durante la emisión seminal, está influenciado por mecanismos neuroendocrinos y quizás también por la presión ejercida debida a la gran concentración de espermatozoides ahí contenida.

\subsection{Características morfológicas del epidídimo}

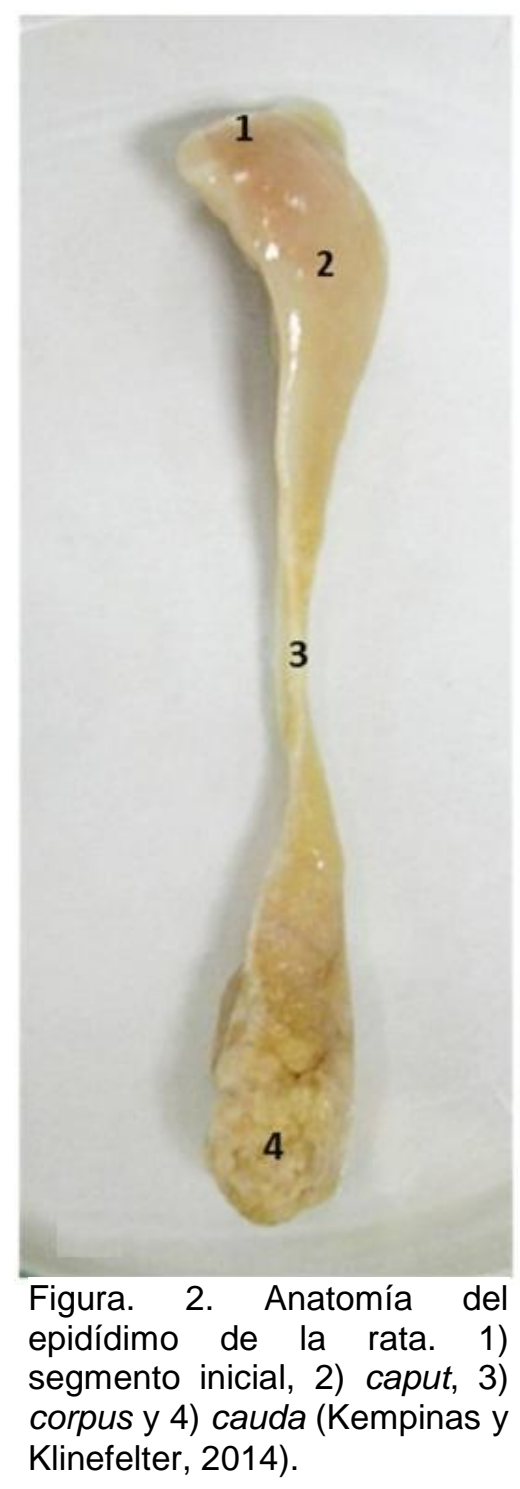

El epidídimo es un órgano tubular, de ahí que se conozca también como ducto/conducto epididimario,

Esta constituido por factores hormonales (gonadotropinas hipofisiarias y hormonas esteroides) y de elementos estructurales como: el entorno intraluminal (lumen, secreciones de moléculas orgánicas de bajo peso molecular, células especializadas, epitelio) matriz extra-tubular (músculo liso, tejido conectivo, elementos vasculares y nervios) y paredes vasculares. Lo cual le confiere el peso al epidídimo (Brooks, 1983; Sullivan y cols., 2007; Setchell y cols., 1994; Cornwall, 2009).

Este órgano se divide en cuatro o más segmentos, según la especie (Setchell y cols., 1994; García-Lorenzana y cols., 2007; Cornwall, 2009). En términos generales se acepta, para la mayoría de los mamíferos, la existencia de: segmento inicial, cabeza, cuerpo y cauda (Fig. 2). Los últimos tres pueden ser denominados también como segmentos proximal (caput), segmento medial (corpus) y segmento distal 
(cauda) (Fig. 2) (Setchell y cols., 1994). Estos segmentos deben denominarse de acuerdo a las especificaciones de la Nómina Anatómica Veterinaria como caput, corpus y cauda (I.C.V.G.A.N., 2005).

El caput (cap) está revestido por un epitelio cilíndrico pseudoestratificado con microvellosidades, mientras que el corpus (cor) y la cauda (cau) por epitelio columnar

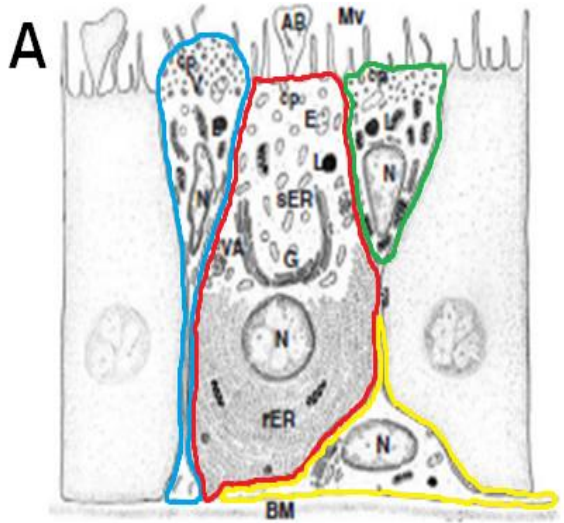

B

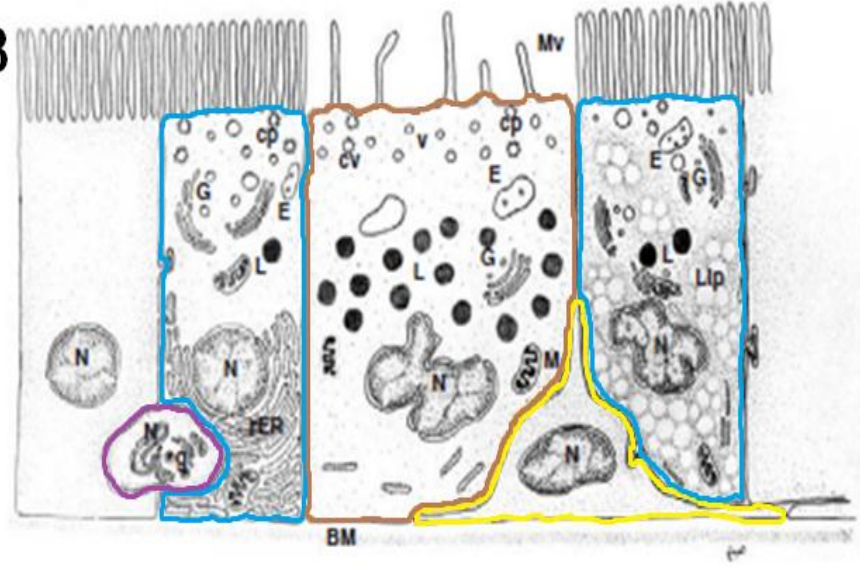

Figura. 3. Representación esquemática de la ultra estructura de las diferentes células, en donde se encuentran organelos cuya organización es diferente y distintiva dependiendo del segmento en donde se encuentren. Se observa en colores: Azul: células estrechas, rojo: principales, verde: apicales, amarillo: basales, anaranjado: claras y morado: halo. A) segmento inicial. B) células principales caput (izquierda) y corpus (derecha). BM: membrana basal, v: vesículas, $\mathrm{cp}$ : fosas descubiertas, $\mathrm{E}$ : endosomas, L:lisosomas, RER: retículo endoplásmico rugoso, G: aparato de Golgi: AB: vesículas apicales, VA: agregados vesiculares, $\mathrm{N}$ : núleo, $\mathrm{MV}$ : microvellosidades y $\mathrm{M}$ : mitocondrias (Robaire y cols., 2006). simple con microvellosidades. Se han descrito distintos tipos celulares en el epitelio epididimario: células principales, basales, apicales, estrechas y claras, que dependiendo del segmento en donde se encuentren su organización es diferente y distintiva (Fig. 3). Las células principales se encuentran a lo largo del tubo epididimario (Robaire y cols., 1988; Trasler y cols., 1988, citados en: Robaire y Hilton, 2015), absorben los fluidos que provienen del testículo y secretan proteínas, serotonina, prostaglandinas, aminoácidos, carbohidratos, lípidos y electrolitos; además de intervenir en la conversión de testosterona a dihidrotestosterona, reacción catalizada por la enzima 5-alfareductasa (Sullivan y cols., 2007). Las células basales se encuentran 
en las tres regiones del epidídimo (Clermont y Flannery, 1970, citados en: Robaire y Hilton, 2015), controlan la secreción de electrolitos desde las células principales mediante la liberación parácrina de prostaglandina-E2, por otra parte las células basales regulan la acidificación del lumen a través de la producción de óxido nitroso y actúan sobre las células claras que están presentes en las regiones de cap, cor y cau (Robaire y cols., 1988; Cooper, 1986; Hamilton, 1975, citados en: Robaire y Hilton, 2015), para estimular la secreción de protones, en este sentido las células claras también son células endocíticas y pueden ser responsables de la depuración de proteínas del lumen y absorben el contenido de las gotitas citoplasmáticas liberadas por los espermatozoides. Las células apicales se encuentran en el segmento inicial y en la zona intermedia, aunque también se han visto en otros segmentos (Sun y Flickinger, 1980; Adamali y Hermo, 1996; Martínez-García y cols., 1995; Hermon y cols., 2000, citados en: Robaire y Hilton, 2015), y las estrechas se encuentran a lo largo del tubo epididimario (Robaire y cols., 1988; Trasler y cols., 1988, citados en: Robaire y Hilton, 2015), estos dos tipos de células participan conjuntamente en la acidificación del fluido seminal. De esta forma, sea de manera individual o concertada, los elementos celulares del epitelio procuran las condiciones necesarias para que los espermatozoides alcancen su maduración, adquieran su motilidad, así como su habilidad para reconocer, fusionarse al ovocito y fecundarlo (Sullivan y cols., 2007; Setchell y cols., 1994; Gregory y Cyr, 2014; Robaire y cols., 2006). Es importante enfatizar que la distribución, proporción y funciones de los tipos celulares descritos, difiere entre los distintos segmentos del epidídimo. Esta situación genera dominios microambientales que proveen a los espermatozoides de factores definidos conforme recorren el órgano (Setchell y cols., 1994). El epitelio epididimario, la matriz extra-tubular y las paredes vasculares, también realizan funciones protectoras. Esto se logra mediante el establecimiento de la denominada barrera hematoepididimaria (BHE), la cual además de proteger a los espermatozoides de los efectos adversos asociados con la ingesta o uso de fármacos, drogas y compuestos nocivos que pudieran provenir de la dieta, previene el contacto directo de las células inmunológicas con los espermatozoides, evitando 
así, su destrucción autoinmune (Setchell y cols., 1994; Cornwall, 2009). Las funciones inmunológicas son llevadas a cabo por las células halo que se encuentran en todo el epitelio epididimario (Robaire y cols., 1988, citados en: Robaire y Hilton, 2015), no solamente se encargan de las funciones de vigilancia inmunológica, sino también fagocitan para llevar a cabo la espermatofagia. Proceso que permite la eliminación de espermatozoides anormales o de aquellos almacenados en la cau epididimaria que no han sido eyaculados en un periodo largo (Setchell y cols., 1994; Cornwall, 2009).

Además de los elementos epiteliales, la pared del epidídimo tiene una capa media constituida por células mioides y una capa externa denominada adventicia, formada por tejido conectivo laxo (Setchell y cols., 1994). En el órgano maduro, el componente amorfo del intersticio funge como barrera que limita la difusión de moléculas. En otras palabras, el componente amorfo del intersticio es fundamental para la organización de los dominios micro-ambientales del epidídimo (Sullivan y cols., 2007). Por otro lado, el intersticio posee un componente celular constituido por células de los linajes nervioso, neuroendocrino, vascular y fibroblástico que no sólo proveen innervación y nutrimento, sino que participan activamente en el control de los procesos de secreción, absorción y remodelación locales. Mención especial debe hacerse a los mastocitos, células provenientes de la médula ósea, que son particularmente abundantes en el epidídimo y que parecen estar involucrados en los procesos de remodelación tisular que ocurren durante el ciclo de involuciónrecrudescencia que se lleva a cabo en el testículo y epidídimo de los mamíferos que muestran reproducción estacional. Así mismo, los mastocitos también parecen regular de forma parácrina la liberación de testosterona $(T)$ desde las células de Leydig (Setchell y cols., 1994; Cornwall, 2009; Amann y cols., 1993).

Es importante destacar que el tiempo que los espermatozoides requieren para recorrer la extensión céfalo-caudal del epidídimo varía entre especies, 8 días en la rata y 12 días en el hombre, asimismo, depende de la frecuencia eyaculatoria. Cabe recordar que la principal fuerza de propulsión de los espermatozoides dentro de la 
luz del epidídimo es de origen neuromuscular y está supeditada a las contracciones rítmicas espontáneas generadas en las paredes del epidídimo, debidas en parte, a la respuesta a los andrógenos, la modulación intrínseca de las neuronas, la actividad nerviosa del hipogástrico y a la acción de diversos neurotransmisores sobre las células mioides del epidídimo (Sullivan y cols., 2007; Setchell y cols., 1994). Es por ello que los espermatozoides que se eyaculan son aquellos que se encuentran en el epidídimo, particularmente en la región caudal (Setchell y cols., 1994).

\subsection{Características morfológicas del espermatozoide}

La estructura morfológica del espermatozoide se constituye por tres regiones: cabeza, cuello y flagelo (Avilés, 2011; Rodríguez-Tobón, 2011).

La cabeza es una estructura de morfología falciforme en mamíferos, en donde se encuentra el acrosoma y el núcleo envueltas por una membrana plasmática, estructuras citoesqueléticas y una pequeña cantidad de citoplasma (Avilés, 2011; Rodríguez-Tobón, 2011). Esta región se subdivide en segmentos: apical, preecuatorial, ecuatorial y post-ecuatorial. El acrosoma reviste los dos primeros tercios de la cabeza del espermatozoide, formada por una membrana interna y una externa. Contiene enzimas hidrolíticas como la acrosina, hialorunidasa y otras hidrolasas y esterasas, las cuales son esenciales para la lisis de la zona pelúcida y la penetración de las células que rodean al ovocito. El núcleo contiene al ácido desoxirribonucleico (ADN) y proteínas nucleares, rodeados por la membrana nuclear; las proteínas asumen funciones estructurales y enzimáticas (Avilés, 2011).

El cuello representa un segmento de unión corto, que separa el flagelo de la cabeza espermática y sirve como conector conformado por columnas segmentadas y una estructura densa y fibrosa nombrada capitulum, también están los centriolos proximal y distal (Avilés, 2011; Rodríguez-Tobón, 2011).

El flagelo está compuesto por un axonema, la vaina mitocondrial, fibras externas densas y una vaina fibrosa. Se divide en tres porciones: pieza media, 
principal y terminal. La pieza media se caracteriza por presentar mitocondrias concentradas en una vaina helicoidal, que rodea al complejo axonema y las fibras densas; el axonema está formado por un par de microtúbulos únicos rodeados por un paquete cilíndrico de dobles microtúbulos en forma de hélice (Avilés, 2011; Rodríguez-Tobón, 2011). La pieza principal se encarga de proporcionar movilidad al espermatozoide, está constituida por vainas fibrosas que son dos columnas longitudinales (dorsal/ventral) conectadas entre sí, rodeando al axomena se encuentra el citoesqueleto y fibras densas del exterior; las vainas fibrosas son encargadas de ser estructuras para proteínas en las vías de señalización, por lo que se les implica en la regulación de la maduración espermática, motilidad, capacitación, hiperactivación y reacción acrosomal. La pieza terminal es la parte distal de la vaina fibrosa y es donde los elementos micro tubulares del axonema terminan (Avilés, 2011).

\subsection{Papel de los andrógenos en el epidídimo}

Cuando los espermatozoides abandonan el testículo, aun no son capaces de fertilizar al ovocito, esta capacidad la adquieren durante su paso por el epidídimo, siendo necesarios los andrógenos. Hormonas responsables de mantener la estructura y función del epidídimo, ya que, son considerados reguladores primarios, es decir, están involucrados en respuestas fisiológicas y de desarrollo, importantes para la función reproductiva masculina (Robaire y Hamzeh, 2011; Seenundun y Robaire, 2007; Romano-Torres y cols., 2006). La próstata y las vesículas seminales obtienen los andrógenos del torrente circulatorio y linfático; el epidídimo recibe un aporte adicional de andrógenos del testículo a través del fluido testicular. Los andrógenos, en el segmento inicial del cap del epidídimo, son importantes para la actividad de secreción de proteínas y reabsorción espermática (Robaire cols., 2006; RodríguezTobón, 2011).

Cabe señalar los efectos de la orquidectomía sobre el epidídimo. La Orquidectomia disminuye ligeramente el peso de este órgano y afecta a los 
espermatozoides (pierden motilidad, así como su capacidad de fertilizar y mueren), debido a la pérdida de andrógenos, estrógenos y factores testiculares. También se afecta el diámetro luminal y la altura de la célula epitelial disminuyéndolos, el estroma intertubular aumenta. Respecto a los diferentes tipos de células epiteliales, las más afectadas en cambios morfológicos son las células principales, ya que son particularmente más sensibles cuando se les priva de andrógenos, sufren una pérdida de microvellosidades apicales, así como la acumulación de lisosomas. Además, se induce una onda de muerte celular apoptótica que comienza en el segmento inicial y después de varios días termina en la cau. La apoptosis en el segmento inicial parece ser causada por la pérdida de andrógenos y de componentes luminales procedentes del testículo. Asimismo, los receptores a andrógenos y la actividad de $5 \alpha$-reductasa en el epidídimo disminuyen (Robaire y cols., 2006; Robaire y cols., 1981; Patrao y cols., 2009).

El reemplazo de $\mathrm{T}$, a niveles suprafisiológicos restaura parcialmente el peso del epidídimo, posiblemente a que aproximadamente el 50\% del peso epididimal se debe a los espermatozoides y al líquido luminal y el otro $50 \%$ a las células especializadas, epitelio, músculo y tejido conectivo. La explicación de lo anterior es que, los receptores a andrógenos y la actividad de $5 \alpha$-reductasa disminuyen, debido a que los andrógenos se encuentran ausentes o disminuidos (Robaire y cols., 1977; Brooks, 1979; De Larminat y cols., 1978; Zhu y cols., 2000, citados en: Robaire y cols., 2006). La restauración de los niveles circulantes de T parece suficiente para revertir los cambios regresivos en las regiones del epidídimo: cap, cor y cau después de la orquidectomia pero no en el segmento inicial, incluso cuando se administran dosis suprafisiológicas de T (Robaire y cols., 2006). 


\section{ANTECEDENTES}

Copular repetidamente hasta la saciedad sexual tiene costos conductuales y fisiológicos, la conducta sexual se inhibe y la expulsión seminal no ocurre.

\subsection{Parámetros seminales}

Los parámetros seminales incluyen: concentración, movilidad, viabilidad y morfología espermáticas; así como el tamaño y peso de tapón seminal obtenido de la vagina (detalles en Lucio y Tlachi-López, 2008).

En condiciones de bioterio, la rata macho puede presentar varias series eyaculatorias repetidamente con la misma o diferentes hembras (mínimo 5; Fernández-Guasti y Rodríguez-Manzo, 2003 y máximo 18; Tlachi-López y cols., 2012). El eyaculado obtenido de la primera serie eyaculatoria presenta 13-20 millones de espermatozoides, 99-100\% muestran morfología normal, 61-67\% están vivos y $70-87 \%$ de ellos muestran movilidad progresiva. El peso del tapón seminal varía entre $100-120 \mathrm{mg}$ y mide $11-13 \mathrm{~mm}$ de longitud y $4-5 \mathrm{~mm}$ de ancho (Lucio y Tlachi-López, 2008).

Los parámetros seminales, particularmente la concentración espermática, así como el peso y tamaño del tapón seminal disminuyen conforme el número de series eyaculatorias se incrementa. Esto se determinó al permitir a los machos realizar 7 series eyaculatorias consecutivas con distintas hembras (Austin y Deswbury, 1986). El eyaculado de la primera y segunda serie eyaculatoria presenta alrededor de 20 millones de espermatozoides, de la tercera a la quinta disminuye de forma gradual. Sin embargo, la reducción abrupta se obtiene en la sexta y séptima series, conteniendo 2 y 1 millón de espermatozoides, respectivamente. El peso de los tapones seminales también disminuye de $100 \mathrm{mg}$ en la primera serie eyaculatoria a $40 \mathrm{mg}$ en la séptima; el tapón seminal se reduce de $13 \mathrm{~mm}$ a solo $7 \mathrm{~mm}$ en su longitud, el ancho se mantiene en 5 mm (Austin y Dewsbury, 1986). Nuestro grupo 
encontró que a los machos que se les permite realizar 8 series consecutivas expelen un tapón diminuto y no hay espermatozoides en el útero (Tlachi-López y cols., 2012).

\subsection{Restablecimiento de la conducta copulatoria}

Se considera que la conducta copulatoria se ha restablecido cuando los valores de los parámetros copulatorios son similares a los valores de los parámetros de los machos controles (Larsson, 1956). Esto ocurre en general, a los 15 días después de la saciedad sexual. Se señala también que la conducta copulatoria está restablecida cuando los machos realizan al menos 5 series eyaculatorias consecutivas, lo que sucede a los 15 días postsaciedad sexual y hasta 8 series a los 18-21 días postsaciedad sexual (Beach y Jordan, 1956). Cabe mencionar que inmediato a la saciedad sexual, la mayoría de los machos puede realizar de 1 a 3 series eyaculatorias (Hisao, 1969), a las 24 horas tras la saciedad sexual el $33 \%$ de los machos copulan; a los 3 días el $63 \%$ y a los 7 días el 100\%, aunque en cada caso los machos realizan solamente una serie eyaculatoria de la cual ya no se restablecen (Fernández-Guasti y Rodríguez-Manzo, 2003). Es importante señalar que todos estos porcentajes se basan exclusivamente en la ejecución del patrón motor de eyaculación sin considerar la evaluación del eyaculado.

Se ha propuesto que los machos son sexualmente potentes cuando fisiológicamente también lo son (Dewsbury, 1982). Esta idea es invalidada por la evidencia de que los machos que realizan 6-8 series eyaculatorias tienen eyaculados con pocos espermatozoides y tapones seminales pequeños (Austin y Dewbury, 1986). Los tapones seminales diminutos no cumplen la función de facilitar el transporte espermático transcervical. Las ratas macho que eyaculan repetidamente dejan de expeler espermatozoides y aquellos que, alcanzan la saciedad sexual y presentan el efecto Coolidge, tampoco eyaculan a pesar de presentar el patrón motor de eyaculación. Por lo tanto, aunque haya machos que desplieguen la conducta copulatoria incluyendo el patrón eyaculatorio no significa que la expulsión del eyaculado ocurra. 
Es importante recordar que la eyaculación comprende dos fases, emisión y expulsión. La emisión seminal implica el cierre del cuello vesical, el transporte de los espermatozoides desde la cau del epidídimo por el vaso deferente hasta llegar a la uretra prostática y la confluencia de las distintas secreciones de las glándulas sexuales accesorias. Tales secreciones glandulares constituyen el plasma seminal que junto con los espermatozoides conforman el semen. La salida impelida de semen por el meato urinario corresponde a la segunda fase de la expulsión seminal (Clément y Giuliano, 2011).

Es común considerar que la emisión seminal debe preceder a la expulsión seminal, es decir, que la estimulación de la uretra prostática producida por la presencia de secreciones glandulares sexuales induce la segunda fase de la eyaculación. Sin embargo, la ausencia de las secreciones de las glándulas sexuales accesorias -debido a la sección de los nervios hipogástricos o la sección del conducto deferente-, no altera la conducta eyaculatoria de la rata macho (Larsson y Swedin, 1971; McGlynn y Erpino, 1974). Incluso, la administración de monosulfato de guanetidina que evita la emisión seminal, no altera la actividad de los músculos bulboesponjosos, cuya contracción es requerida durante la expulsión seminal (Holmes y Sachs, 1991). Este hallazgo indica que la estimulación de la mucosa uretral no es necesaria para la generación de los patrones motores rítmicos asociados con la respuesta eyaculatoria durante la cópula (Holmes y Sachs, 1991). Las ratas macho sexualmente saciadas pueden ser consideradas como un modelo natural a la evidencia de que la aparición de emisión seminal no es crítica para ejecutar el patrón motor de la eyaculación.

\subsection{Restablecimiento del eyaculado}

El costo fisiológico de la cópula repetida repercute en el eyaculado e implica la disminución drástica de las características físicas (color, solidez) del tapón seminal aunado a la ausencia de espermatozoides. La repercusión de copular hasta la saciedad sexual abole toda expulsión (Tlachi-López y cols., 2012; Lucio y cols., 
2014). Ambas situaciones implican el agotamiento de las secreciones de las glándulas sexuales accesorias (Pesah y Kochva, 1975; Purvis y cols., 1986), sumadas a la disminución drástica de la concentración de espermatozoides en el epidídimo (Austin y Dewsbury, 1986; Toner y Adler, 1986; Tlachi-López y cols., 2012).

En un trabajo anterior encontramos que el eyaculado se restablece gradualmente (Lucio y cols., 2014). A los 5 días postsaciedad sexual, los machos realizan el patrón motor de eyaculación sin lograr expeler nada. El eyaculado de esos mismos machos probados a los 10 días postsaciedad sexual consiste de un tapón seminal con características físicas (peso y tamaño) similares a los de machos no saciados sexualmente. Las características físicas restablecidas del tapón indican que las vesículas seminales y las glándulas coagulantes ya están recuperadas a los 10 días postsaciedad. Sin embargo, la falta de adhesión del tapón a la vagina y al cérvix evita el transporte espermático transcervical, provocando que los espermatozoides permanezcan en la vagina (Lucio y cols., 2014). En otro trabajo mostramos que la adhesión del tapón seminal depende de las secreciones de la próstata (Tlachi-López y cols., 2011). Nuestros trabajos indican que la recuperación de la secreción prostática es más lenta que el de las seminales y coagulantes. La recuperación completa de las secreciones de las glándulas accesorias (seminales, coagulantes y próstata) ocurre a los 15 días después de la saciedad sexual, cuando los tapones seminales fuertemente adheridos a la vagina permiten el transporte de los espermatozoides de la vagina a los cuernos uterinos. Sin embargo, lo que aún no se restablece a los 15 días postsaciedad es la concentración espermática ya que representa una cuarta parte de la concentración normal. i.e. alrededor de 6 millones de espermatozoides en lugar de 20-25 millones (Lucio y cols., 2014). Como se mencionó estos machos realizaron una serie eyaculatoria a los 5, 10 y 15 días después de la saciedad sexual. Por lo que a otro grupo de machos les permitimos realizar una serie eyaculatoria hasta los 15 días postsaciedad, obteniendo mayor concentración espermática (15 millones) (Lucio y cols., 2014). Nuestros trabajos 
anteriores indican que el plasma seminal, provisto por las distintas glándulas sexuales accesorias, se recupera antes que la cuenta espermática (Lucio y cols., 2013).

\subsection{Hallazgos histológicos en testículo y epidídimo posterior a la saciedad sexual.}

El análisis histológico preliminar de los testículos de animales sexualmente saciados mostró que los túbulos seminíferos presentaban descamado adluminal germinal a los 15 días de reposo postsaciedad sexual (Fig. 4 A-B), en tanto que en los ejemplares con 21 días de reposo este descamado no se observó (más detalles en GarcíaLorenzana y cols., 2014). Este descamado adluminal germinal, también lo han observado en una especie estacional, durante la regresión testicular, el cual está constituido por grupos de células germinales vivas que ocupan la región luminal de los túbulos seminíferos y que incluyen espermatocitos primarios postpaquiténicos, espermatocitos secundarios y espermátidas (Fig. 4 C-D) (Dadhich y cols., 2013).

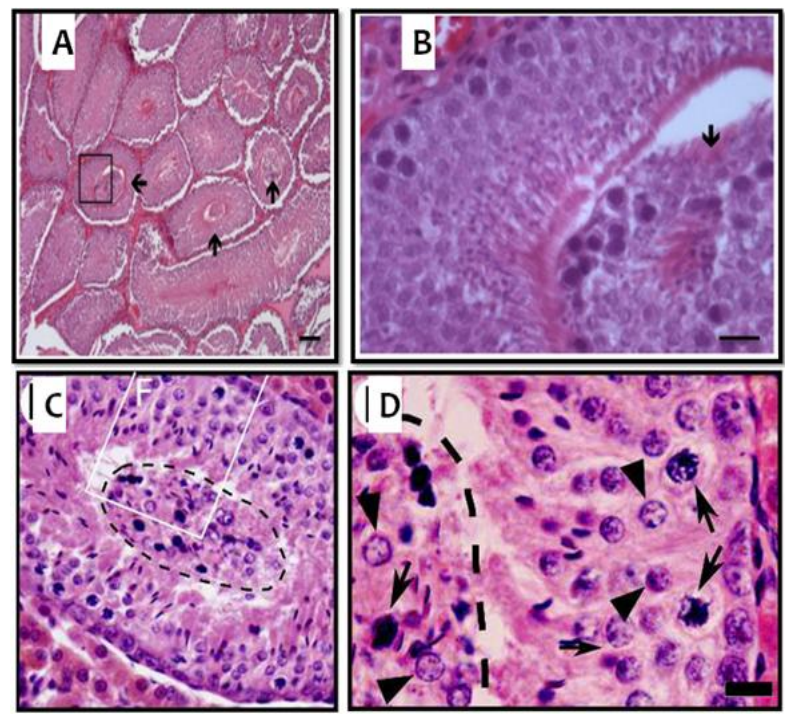

Figura 4. Descamado adluminal germinal en testículo. En rata Wistar, 15 días posteriores a la saciedad sexual (A-B) (García-Lorenzana et al., 2014). Regresión testicular en Talpa occidentalis (C-D) (Dadhich y cols., 2013). La luz de algunos túbulos seminíferos muestran abundantes células redondas y restos celulares (A-C). Ampliación de los recuadros en $B-D$, se muestran espermatocitos y espermatidas redondas en el lumen $(\mathrm{H}-\mathrm{E}$, barra en $\mathrm{A}=100 \mu \mathrm{m}$; $\mathrm{B}=20 \mu \mathrm{m}, \mathrm{C}=25 \mu \mathrm{m}$ y $\mathrm{D}=10 \mu \mathrm{m})$.

En cuanto a resultados que se han obtenido en el grupo de trabajo con relación al epidídimo se realizó un análisis cualitativo en el que se observó que en la cau epididimaria se presenta disminución espermática en la luz del tubo de los animales saciados sexualmente en los días 2 y 6 postsaciedad sexual, comenzando 
a recuperarse a los 15 días y terminando de recuperarse a los 21 días (Fig. 5) (García-Lorenzana y cols., 2013).

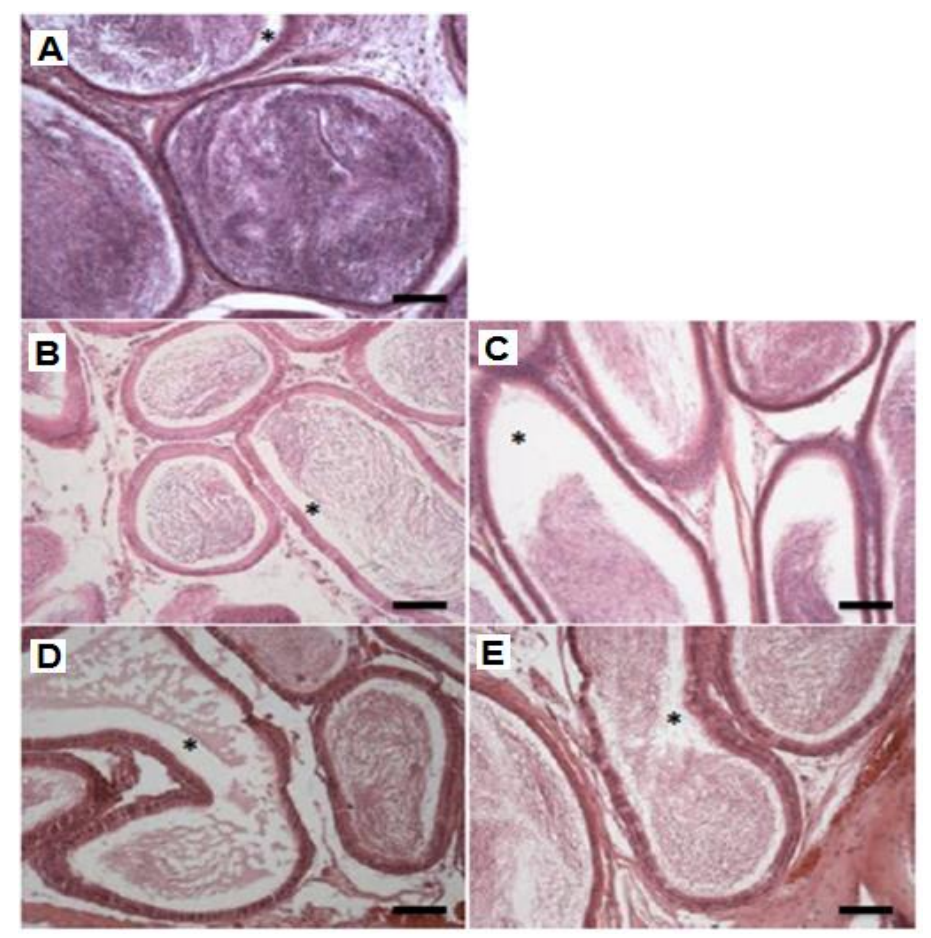

Figura 5. Cauda del epidídimo de rata Wistar. El * muestra el área luminal libre de espermatozoides. A) control, B) 2, C) 6, D) 15 y E) 21 días después de la saciedad sexual. Se observa cómo va aumentando la luz en el tubo epididimario en los días 2-15 y esta disminuye en el día 21 (H-E; barras y aumento original: $100 \mu \mathrm{m}$ ) (García-Lorenzana y cols., 2013).

Lo anterior podría ser una evidencia morfológica de la disminución de T local como lo muestra Dadhich y cols., (2013) indicando que a ello se debe el descamado adluminal germinal.

\subsection{Andrógenos en la saciedad sexual}

A través de la interacción con los receptores a andrógenos (RA) que se encuentran en diferentes áreas del cerebro, los andrógenos como la $T$ y la $5 \alpha$-dihidrotestosterona están involucrados en la regulación del comportamiento reproductivo masculino (Phillips-Farfánn y Fernández-Guasti, 2009). 
Las áreas cerebrales afectadas por la saciedad sexual son: el núcleo accumbens, el área preóptica media (APOm) y el núcleo ventromedial hipotalámico (VMH). $24 \mathrm{~h}$ después de la saciedad sexual, estas áreas mostraron reducción en la densidad de RA y también observaron que el apareamiento se redujo. A las $48 \mathrm{~h}$ observaron una disminución de estos receptores en el APOm y un $70 \%$ de los machos presentaban inhibición completa del comportamiento sexual; a las $72 \mathrm{~h}$ hay un aumento de los RA en el APOm y una sobre expresión de estos receptores en el núcleo del lecho de la estría terminalis (BST), núcleo septal lateral (SL) y la amígdala medial (AMe), mientras que el $70 \%$ de los machos eyacularon una vez; a los 7 días los RA se recuperaron a niveles basales y el $100 \%$ de los machos eyacularon dos veces (Romano-Torres y cols., 2006).

En cuanto a los niveles de $\mathrm{T}$ en suero asociados con la saciedad sexual se triplicaron inmediatamente a la saciedad sexual y disminuyeron a niveles basales a las $24,48,72 \mathrm{~h}$ y 7 días posteriores a la saciedad sexual (Bonilla-Jaime y cols., 2006; Romano-Torres y cols., 2006). Sin embargo, en testículo y epidídimo no se ha determinado la concentración de la T local. 


\section{JUSTIFICACIÓN}

Los machos que presentan saciedad sexual han sido estudiados desde la perspectiva conductual (Larsson 1956; Beach y Jordan, 1956), endocrinológica y farmacológica (Rodríguez-Manzo y Fernández-Guasti 1994; Fernández-Guasti y Rodríguez-Manzo 2003), dejando al margen aspectos de la fisiología del eyaculado. Ha sido común considerar que los machos que realizan la conducta eyaculatoria expelen semen y los sexualmente saciados no han sido la excepción. Dado que en la literatura se indicaba que el eyaculado disminuye conforme se incrementa el número de series eyaculatorias, nos resultaba extraño suponer que los machos saciados sexualmente tuvieran semen que expeler. En la literatura también se indica como gradualmente se recupera la conducta copulatoria olvidándose de la recuperación del eyaculado. De ahí que nos diéramos a la tarea de analizar el eyaculado en distintos días después de la saciedad sexual. Uno de esos estudios realizado por Lucio y cols., (2014), en donde analizan la copulación sin presencia de expulsión seminal, a consecuencia de la saciedad sexual y el efecto Coolidge, el análisis incluyó las características del eyaculado en tres pruebas realizadas cada 5 días después de la saciedad sexual. Así mismo, se determinó cuando los animales fueron capaces de inducir la preñez. Encontraron que a los 5 días postsaciedad sexual no hubo tapón seminal adherido a las paredes vaginales ni espermatozoides en cuernos uterinos. A los 10 días hubo tapón seminal no adherido a las paredes vaginales aunque de tamaño y peso similar al de los machos controles. Esta falta de adhesión evitó que los espermatozoides llegaran al útero, permaneciendo en la vagina. A los 15 días postsaciedad, el tapón seminal estaba adherido a la vagina y los espermatozoides en el útero, aunque significativamente la cuenta fue menor $(6.5$ millones versus 20 millones para los machos controles). Dicha cuenta espermática incrementó 15 millones cuando a los animales saciados se les mantuvo en abstinencia sexual durante 15 días. Además, los animales saciados que se mantuvieron en abstinencia sexual y que después cohabitaron durante 15 días con hembras fueron capaces de inducir preñez al $50 \%$ de ellas durante los primeros 5 días, al $40 \%$ durante el resto 
del tiempo de cohabitación. Todos estos hallazgos dirigieron nuestra atención en estudiar a los dos órganos directamente relacionados con la formación, maduración y almacenamiento de los espermatozoides, el testículo y el epidídimo. Por lo tanto, en esta propuesta de investigación sólo determinamos los cambios morfológicos del epidídimo durante el periodo postsaciedad sexual hasta la recuperación. También se analizaron las características de los espermatozoides de las diferentes regiones del epidídimo. De este modo, se hizo el seguimiento de la maduración y el almacenamiento de los espermatozoides antes de ser expelidos durante la eyaculación. 


\section{PREGUNTAS DE INVESTIGACIÓN}

¿El epidídimo presenta cambios morfológicos en el periodo postsaciedad sexual? ¿Cuáles son los cambios morfofuncionales que presenta el epidídimo durante el proceso de recuperación de los parámetros espermáticos postsaciedad sexual? ¿Cuáles son las características del epitelio epididimario en el periodo de postsaciedad sexual? ¿Cuándo se recupera la concentración espermática en la cauda epididimaria en los animales que presentaron saciedad sexual?

\section{HIPÓTESIS}

Si la ausencia de espermatozoides provocada por la saciedad sexual depende del epidídimo, entonces la citología del epitelio del conducto epididimario y algunos parámetros espermáticos estarán modificados en los primeros días después de la saciedad sexual y mostrará recuperación conforme avanza el tiempo de reposo postsaciedad sexual.

\section{OBJETIVO GENERAL}

Identificar los cambios en la morfología epididimaria y determinar la concentración espermática, durante los días posteriores a la saciedad sexual de la rata.

\section{OBJETIVOS PARTICULARES}

1) Determinar el peso del epidídimo de los grupos controles y posteriores a la saciedad sexual.

2) Describir la citología del epitelio epididimario en caput, corpus y cauda en grupos controles y después de la saciedad sexual $(0,4,8,12,16,20,24$ y 28 días).

3) Determinar los cambios en la viabilidad, morfología y concentración espermática en caput, corpus y cauda en grupos controles y después de la saciedad sexual $(0,4$, $8,12,16,20,24$ y 28 días). 


\section{MATERIAL Y MÉTODOS}

\subsection{Diseño experimental}

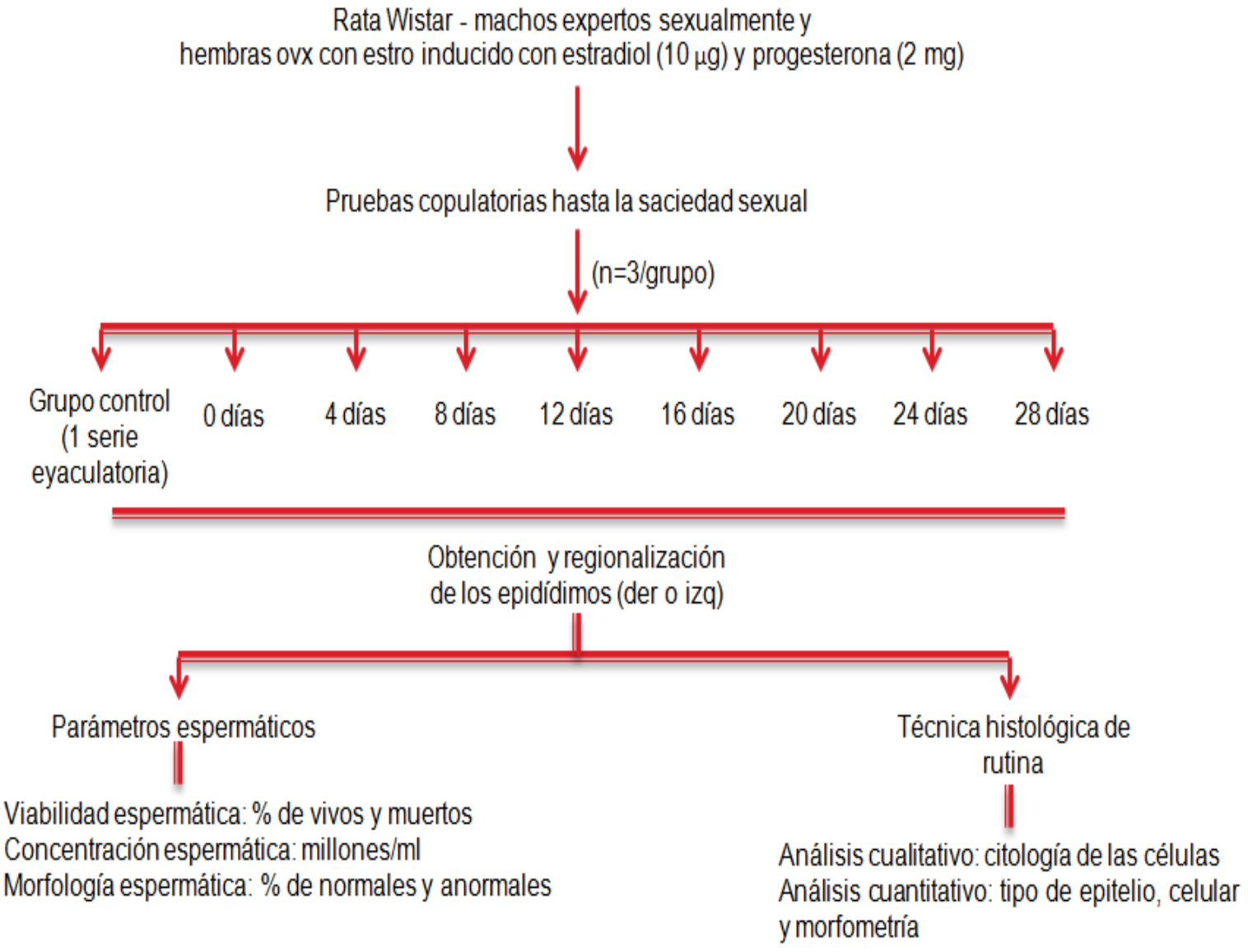

\subsection{Animales}

Se utilizaron ratas Wistar (machos y hembras sexualmente maduras) del bioterio de la Universidad Autónoma Metropolitana-Iztapalapa. Se mantuvieron bajo condiciones estándar (temperatura controlada de $20 \pm 2{ }^{\circ} \mathrm{C}$ y ciclo de 12/12 luz-oscuridad). El agua y el alimento en "pellets" estuvo disponible ad libitum. El protocolo se realizó de acuerdo con los Lineamientos de Manejo de los Animales de Bioterio y de la Comisión de Ética de la Universidad Autónoma Metropolitana-Iztapalapa (NOM-062ZOO-1999). 


\subsection{Pruebas copulatorias}

Las pruebas consistieron en aquellas de entrenamiento copulatorio y las de saciedad sexual. En ambas se usaron hembras ovariectomizadas a las que se les indujo hormonalmente el estro, mediante la administración subcutánea de $10 \mu \mathrm{g}$ de benzoato de estradiol y $2 \mathrm{mg}$ de progesterona a las $48 \mathrm{~h}$ y $4 \mathrm{~h}$ antes de los encuentros copulatorios, respectivamente. Las pruebas se realizaron durante la fase oscura del ciclo de luz-oscuridad; dentro de un cilindro de plexiglás, se colocaron durante 5 minutos al macho para su habituación, posteriormente se introdujo a la hembra receptiva.

Registro de parámetros copulatorios: Latencia de monta (tiempo que transcurre desde que se introduce a la hembra en el cilindro hasta que ocurre la primera monta); latencia de intromisión (tiempo que transcurre desde que se introduce a la hembra en el cilindro hasta que ocurre la primera intromisión); latencia de eyaculación (tiempo que transcurre desde la primera intromisión hasta que ocurre la eyaculación); número de montas (cantidad de veces en las que el macho despliega este patrón motor) y número de intromisiones (cantidad de veces en las que el macho despliega este patrón motor). Cabe recordar que el conjunto de montas e intromisiones que culminan con la eyaculación constituyen una serie eyaculatoria.

Pruebas de entrenamiento: para adquirir experiencia sexual a los machos se les permitió realizar cuatro pruebas copulatorias con hembras sexualmente receptivas. Las pruebas terminaban a los 15 minutos, si el macho no realizaba nada o solo patrones de monta; a los 30 minutos después de la primera intromisión o cuando el macho presentaba el patrón de eyaculación. Fueron considerados como machos sexualmente expertos aquellos que eyacularon en las cuatro pruebas en un tiempo igual o menor a 15 minutos. 


\subsection{Saciedad sexual}

A los machos sexualmente expertos se les permitió realizar series copulatorias repetidas hasta que mostraron saciedad sexual, es decir, cuando dejaron de realizar montas o intromisiones en un lapso igual a 30 minutos posteriores a la última eyaculación. También se registraron: número de series eyaculatorias (cantidad de series eyaculatorias realizadas para alcanzar la saciedad sexual) e intervalo posteyaculatorio (tiempo que transcurre entre la eyaculación y la intromisión de la subsecuente serie eyaculatoria.

\subsection{Recuperación postsaciedad sexual}

Una vez que los machos cumplieron el criterio de saciedad se mantuvieron en jaulas individuales para su gradual recuperación. Así hubo grupos de machos a los que no se les permitió la recuperación, es decir, fueron sacrificados inmediato a la saciedad y constituyeron el grupo de 0 días. A otros machos de les permitió la recuperación de 4, 8, 12, 16, 20, 24 y 28 días. Cada grupo estuvo constituido por 3 machos. Además, se consideró machos control (a los que solo se les permitió realizar una serie eyaculatoria; $n=3$ ).

Los machos controles se trabajaron antes de comenzar con los animales postsaciedad sexual. En cuanto a los grupos experimentales, transcurridos los distintos periodos de postsaciedad sexual, los machos fueron sometidos a pruebas copulatorias de una serie eyaculatoria. Inmediatamente después, fueron dislocados para obtener las muestras biológicas.

\subsection{Obtención de muestras del epidídimo}

Los animales fueron sacrificados humanitariamente, de acuerdo con la NOM-033ZOO-1995, inmediatamente después, fueron colocados en posición supina, realizando una incisión ventral desde la región terminal del esternón hasta la sínfisis púbica, tanto en piel como en la pared muscular, para tener acceso amplio al aparato reproductivo. Se localizaron los testículos y adyacentes a estos se encontraron los 
epidídimos, los cuales se extrajeron cuidadosamente con pinzas. Se pesaron completos y por región (cap, cor y cau) en una balanza analítica, para analizar si hubo alguna diferencia entre animales control vs saciados sexualmente. En seguida, aleatoriamente un epidídimo se disecó para determinar los parámetros espermáticos, el otro epidídimo se fijó, por inmersión en Bouin Dubosq y se procesó con la técnica histológica. Los epidídimos se disecaron regionalmente (cap, cor y cau), quitándoles la grasa.

\subsection{Determinación de parámetros espermáticos del epidídimo}

Cada una de las regiones epididimarias (cap, cor y cau) fueron depositadas en una caja de cuatro pozos y se trituró, utilizando $500 \mu \mathrm{l}$ de solución Ringer a $34{ }^{\circ} \mathrm{C}$, después se mezcló la muestra epididimaria con medio Ringer y se dejó por unos minutos agitando suavemente para provocar el vaciamiento de los espermatozoides contenidos. La suspensión se filtró con una malla de licra de diámetro de trama de 20 $\mu \mathrm{m}$. Posteriormente, se enjuagó nuevamente con $500 \mu \mathrm{l}$ de Ringer, para filtrar el remante de material biológico. Los espermatozoides obtenidos fueron lavados por centrifugación, 500 veces la fuerza de gravedad, por 5 minutos, con dos repeticiones. En cada centrifugación, se eliminó el sobrenadante y el botón de espermatozoides se resuspendió en $1000 \mu$ lde Ringer.

Las muestras de espermatozoides lavados que se obtuvieron de cada una de las tres regiones del epidídimo con el procedimiento anterior, fueron evaluadas para determinar su calidad en términos de viabilidad y su integridad morfológica de acuerdo con los criterios establecidos en el manual de la Organización Mundial de la Salud (WHO, 2012), adaptándose para espermatozoides de ratas (Téllez-López y cols., 2013).

La determinación de la concentración espermática se realizó en una cámara de Neubauer; se adicionó una alícuota de $10 \mu \mathrm{l}$ de espermatozoides (dilución 1:50) en la cámara, se dejó reposar por 1 minuto, y se observó en un microscopio fotónico para realizar el conteo. 
La determinación de la viabilidad se realizó utilizando la tinción de EosinaNigrosina. Se colocaron $10 \mu \mathrm{l}$ de espermatozoides en un portaobjetos y se mezclaron con una alícuota de $10 \mu \mathrm{l}$ de la tinción. Se realizó un frotis y dejándolo secar al aire se hizo el conteo de 100 espermatozoides. Los espermatozoides vivos fueron aquellos que no mostraron coloración, mientras que los muertos fueron los que si la presentaron.

La determinación de las anormalidades morfológicas se realizó tomando 10 $\mu \mathrm{l}$ de solución fijadora (PAF 1\%) y $10 \mu \mathrm{l}$ de la muestra que se obtuvo de la extracción de espermatozoides, colocándolos en un tubo de microcentrífuga de $1.5 \mathrm{~mL}$. Posteriormente, se agitaron los tubos y se tomaron $10 \mu \mathrm{l}$, colocándolos en un portaobjetos y realizando un frotis. Dejándolo secar por unos minutos, para realizar la técnica de tinción de Papanicolau. Se hizo un conteo de las anormalidades en cabeza, pieza media, flagelo y si presentaban gota citoplasmática.

\subsection{Técnica histológica y análisis morfométrico del epidídimo}

Los epidídimos obtenidos se fijaron en Bouin Dubosq (para morfología); posteriormente se hicieron lavados para eliminar el exceso del fijador, con etanol del $70^{\circ}$ Gay Lussac. Las regiones epididimarias se procesaron con etanol de diferentes grados Gay Lussac (80ㅜ $96^{\circ}$ y anhidro) en donde se deshidrataron. Se aclararon con $\mathrm{OH}$-xileno y xileno, fueron infiltradas en parafina. El anterior procedimiento se realizó en un procesador de tejidos (Leica, TP 1020). La inclusión final de cada región se realizó utilizando escuadras de Leukart. Se obtuvieron cortes longitudinales seriados de 5 micrómetros de espesor con un micrótomo de rotación (modelo Jung Histocut, LEICA). La tinción para el estudio morfológico fue la de Hematoxilina y Eosina (H-E), con las regiones epididimarias fijadas con Bouin.

El análisis histológico se realizó con un microscopio Axioskop II, con cámara axioCamMRc5 y software Axiovision 4.8 (Carl Zeiss). El análisis morfométrico de los conductos epididimarios por región comprendió el área epitelial, altura del epitelio, 
área del aglomerado de espermatozoides. También se hizo un conteo del tipo de epitelio y de los tipos celulares de la siguiente manera:

Se revisaron catorce túbulos epididimarios en ocho cortes de dos laminillas (4 cortes por laminilla). El criterio de inclusión fue considerar sólo los túbulos redondos, aquellos alargados podrían tener variaciones mayores en el área.

El análisis morfométrico de los conductos epididimarios por región (cap, cor y cau) comprendió el área del epitelio ( $\mathrm{AE}$ ), área del aglomerado de espermatozoides (AAs) y altura del epitelio.

Las áreas del epitelio epididimario se obtuvieron mediante las siguientes fórmulas:

$\mathrm{AE}=\mathrm{DB}-\mathrm{DA} \quad \mathrm{DB}=$ dominio basal $\mathrm{DA}=$ dominio apical

ÁAs= Área obtenida de la medición en micrómetros

Área luminal libre de espermatozoides (ALLE) $=$ DA - AAs

Área luminal total $(A L T)=A A s+A L L E$

Altura = La suma de las cinco alturas que se tomaron en la circunferencia del túbulo epididimario.

La diferenciación numérica del tipo de epitelio se determinó mediante el conteo de 14 campos de ocho cortes en dos laminillas.

La diferencia numérica del conteo de los diferentes tipos celulares se evaluó considerando las células que se encontraban en tres tubos epididimarios a lo largo de cada una de las tres regiones (cap, cor y cau)

\subsection{Análisis estadístico}

En el análisis histológico se hizo de los datos en bruto y se utilizó la U Mann-Whitney para la morfometría y tipo celular para comparar cada grupo experimental con el control. Para el tipo de epitelio y los parámetros espermáticos se utilizó una ANOVA, seguida de la post hoc Tukey-Kramer. 


\section{RESULTADOS}

\subsection{Peso del epidídimo}

Los pesos de los epidídimos fueron totales y por regiones caput (cap), corpus (cor) y cauda (cau) posterior a la saciedad sexual. Los pesos total y cap del epidídimo aumentó significativamente $(\mathrm{P}<0.05)$ después de la saciedad sexual: peso total en los días 8,12 y 16 (control $=0.572 \pm 0.005$ vs $0.753 \pm 0.007,0.753 \pm 0.010$ y $0.733 \pm 0.015$ g; Fig. 6A) y del cap en los días $0,8,12$ y 16 (control $=0.287 \pm 0.005$ vs $0.392 \pm 0.014$, $0.472 \pm 0.003,0.453 \pm 0.005$ y $0.365 \pm 0.029 \mathrm{~g}$; Fig. 6B); en cor el peso disminuyó significativamente $(P<0.05)$ en el día 4 (control $=0.065 \pm 0.0008$ vs $0.031 \pm 0.005 \mathrm{~g}$; Fig. $6 C$ ); y en cau aumentó significativamente $(P<0.05)$ en el día 16 (control $=0.219 \pm 0.003$ vs $0.315 \pm 0.026$ g, Fig. $6 \mathrm{D})$. 

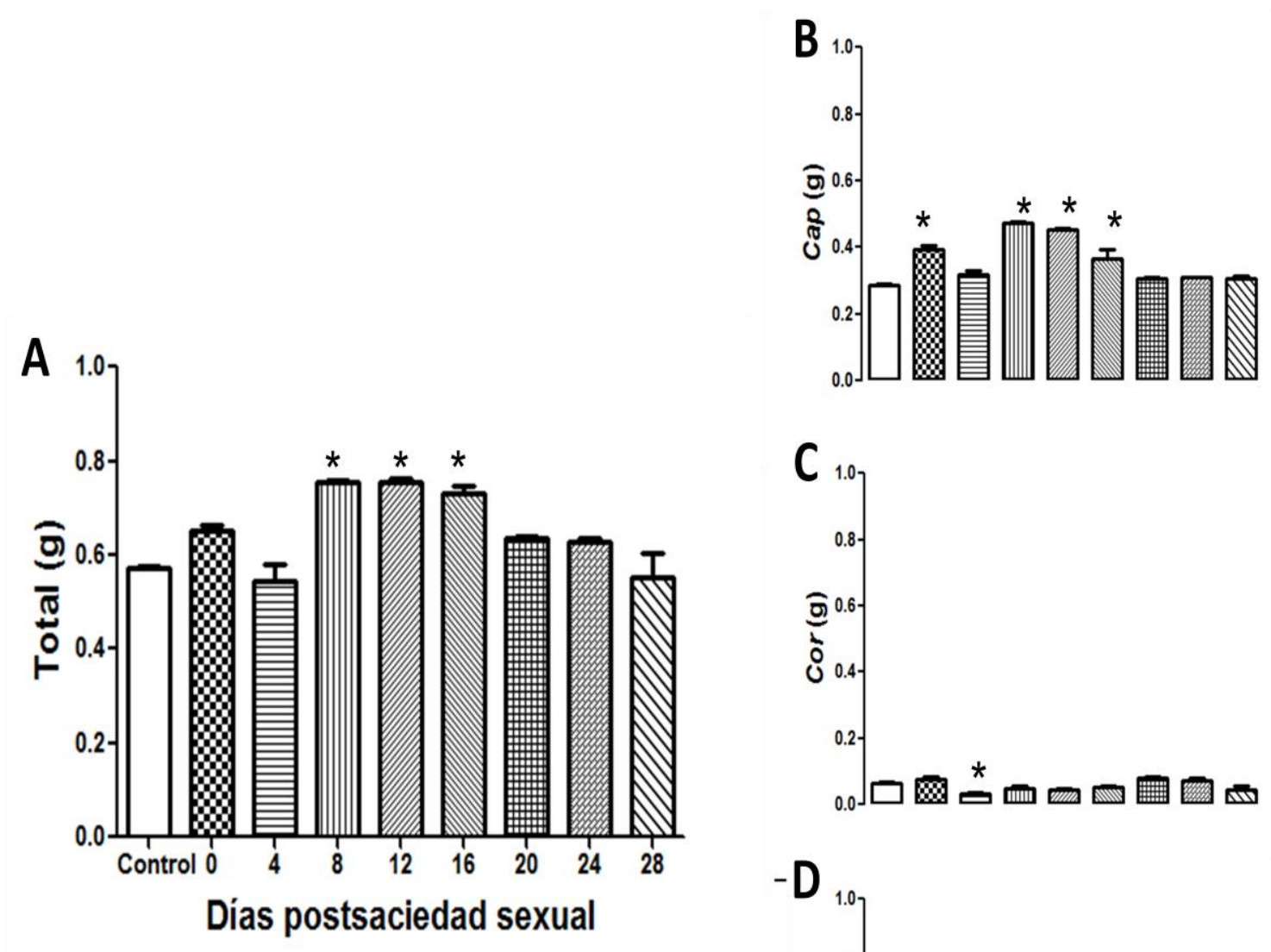

Figura 6. Peso del epidídimo en los días posteriores a la saciedad sexual. A) total, B) cap, C) cor y D) cau. Los datos se expresan en promedio \pm ee, ANOVA, TukeyKramer, ${ }^{*} \mathrm{P}<0.05, \mathrm{n}=3$.

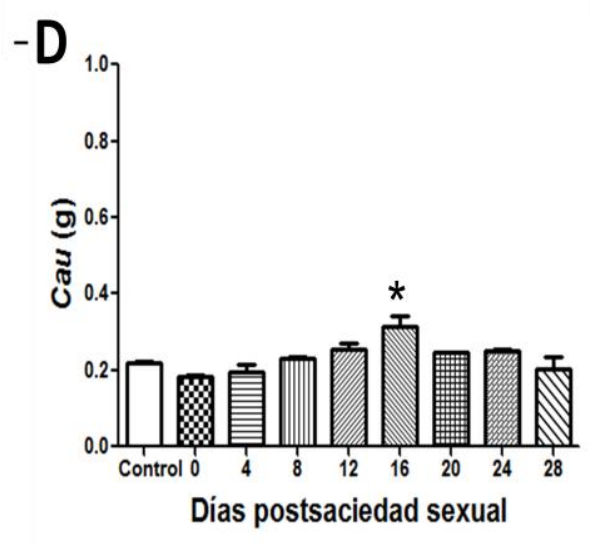




\subsection{Histología del epidídimo}

\subsubsection{Análisis cualitativo del epidídimo}

La tinción utilizada para el análisis cualitativo fue la de Hematoxilina y Eosina (H-E) que emplea colorantes que tiñen todas las estructuras celulares (núcleo y citoplasma) y tisulares (matriz extracelular). Se tiñen selectivamente el núcleo con la Hematoxilina, en tanto que el citoplasma y algunos elementos tisulares extracitoplásmaticos (como la colágena) con la Eosina; lo que permite observar las características estructurales, de composición química general y por tanto funcionales, es decir, permite diferenciar los elementos celulares del resto de las estructuras del tejido.

Se analizaron las tres regiones del epidídimo: cap, cor y cau, teñidas con H-E. La tinción observada es de una tonalidad basófila a acidófila en grupos controles y en los días posteriores a la saciedad sexual en las tres regiones del epidídimo, en los diferentes tipos celulares que constituyen el epitelio (Figs. 7-9).

La tinción permitió distinguir cambios en la intensidad de la basofilia y la acidofilia del núcleo y el citoplasma, respectivamente, entre el epitelio del grupo control y de los días posteriores a la saciedad sexual. En el cap el núcleo pasa de basófilio leve aintenso, en el caso del citoplasma va de acidófilo intenso a leve y moderado, para después regresar a la tinción nuclear y citoplásmatica característica del grupo control (Fig. 7). En el cor la basofilia del núcleo y la acidofilia del citoplasma pasan de leves, en el grupo control, a intensos en los primeros 16 días posteriores a la saciedad sexual, para volver a la tinción propia del control en los días del 20 al 28 postsaciedad sexual (Fig. 8). En la cau se observó basofilia nuclear y acidofilia citoplásmica intensa en el grupo control, mientras que en los días del 0 al 16 se apreció mayor intensidad de la tinción, tanto basófilia como acidófilia; para pasar en los días 20 al 28 a basofilia y acidosilia características del grupo control; no obstante en el día 8 se observaron regiones con células con basofilia y acidofilia leves (Fig. 9). 
En cuanto a otras características en el epitelio epididimario, se observaron prolongaciones citoplásmicas (estereovellosidades) en cada región. En las tres regiones (cap, cor y cau) del tejido de los grupos controles, las estereovellosidades se encuentran en mayor cantidad. En tejido de los grupos postsaciedad sexual, en la región del cap se presenta recuperación de las estereovellosidades en el día 28 posterior a la saciedad sexual (Fig. 7). En el cor, las estereovellosidades se encuentran reducidas en cantidad y tamaño en los días postsaciedad sexual (Fig. 8). En la cau se observa ligera disminución de las estereovellosidades, pero no se pierden totalmente en los días posteriores a la saciedad sexual (Fig. 9). 

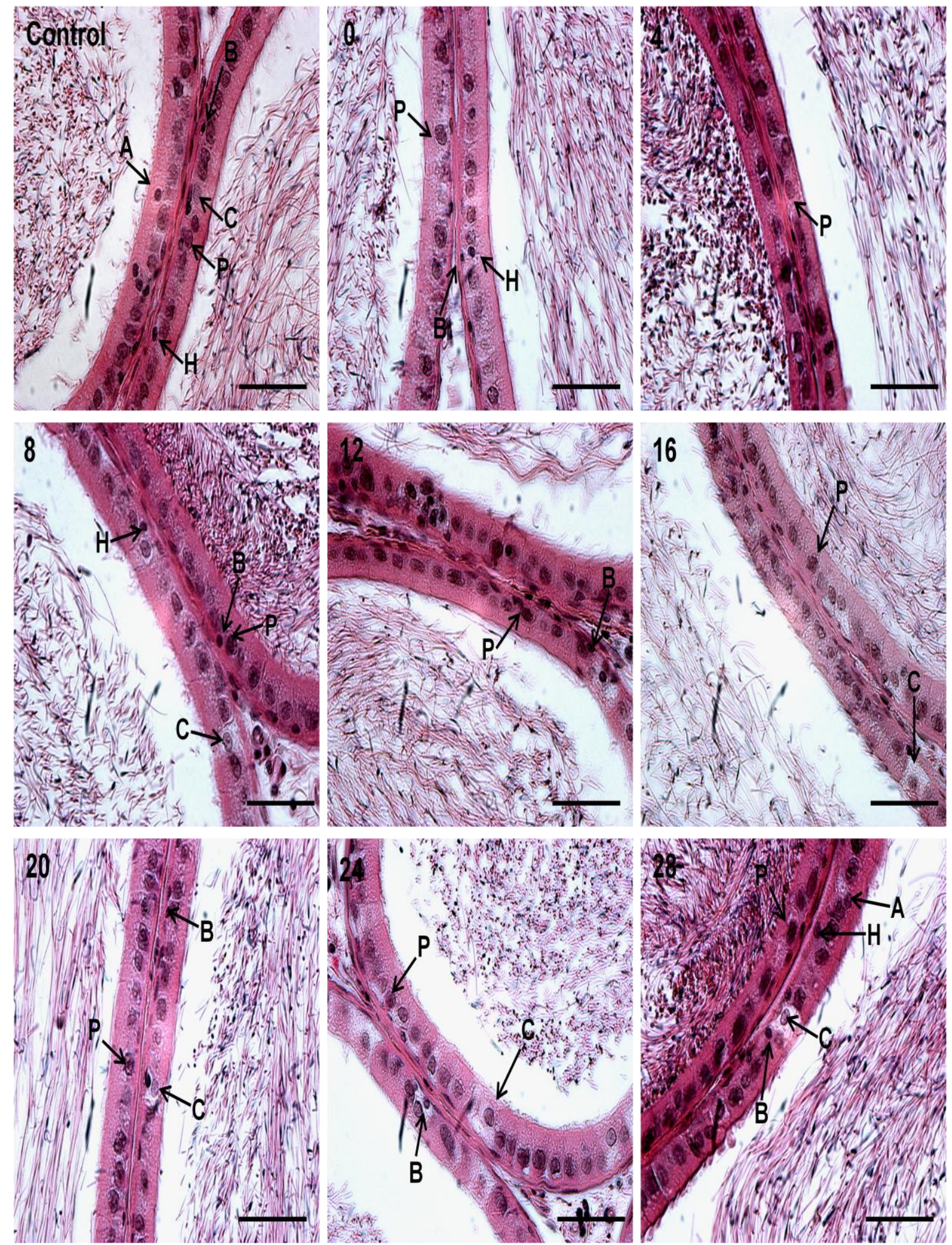

Figura 7. Microfotografías de cortes transversales del caput del epidídimo después de la saciedad sexual. Se nota la basofilia y acidofilia en los diferentes tipos celulares. Los números representan los días posteriores a la saciedad sexual y las letras representan los tipos celulares. P: principales, $\mathrm{B}$ : basales, $\mathrm{A}$ : apicales, $\mathrm{C}$ : claras y $\mathrm{H}$ : halo (H-E; barras y aumento original: $500 \mu \mathrm{m}$ y $\mathrm{x} 400)$. 


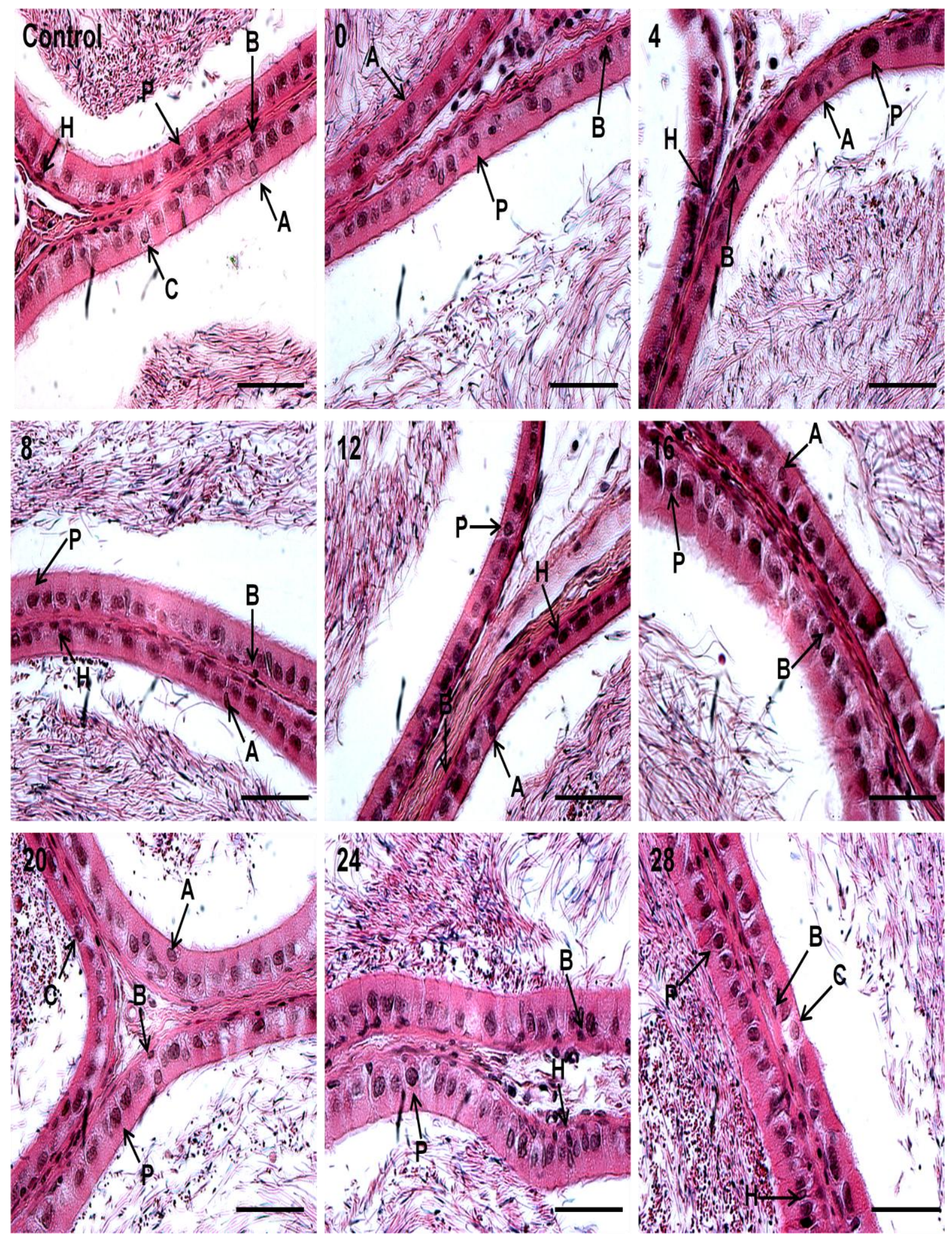

Figura 8. Microfotografía de cortes transversales del corpus del epidídimo después de la saciedad sexual. Se nota la basofilia y acidofilia en los diferentes tipos celulares. Los números representan los días posteriores a la saciedad sexual y las letras representan los tipos celulares. P: principales, $\mathrm{B}$ : basales, $\mathrm{A}$ : apicales, $\mathrm{C}$ : claras y $\mathrm{H}$ : halo (H-E; barras y aumento original: $500 \mu \mathrm{m}$ y $\mathrm{x} 400)$. 

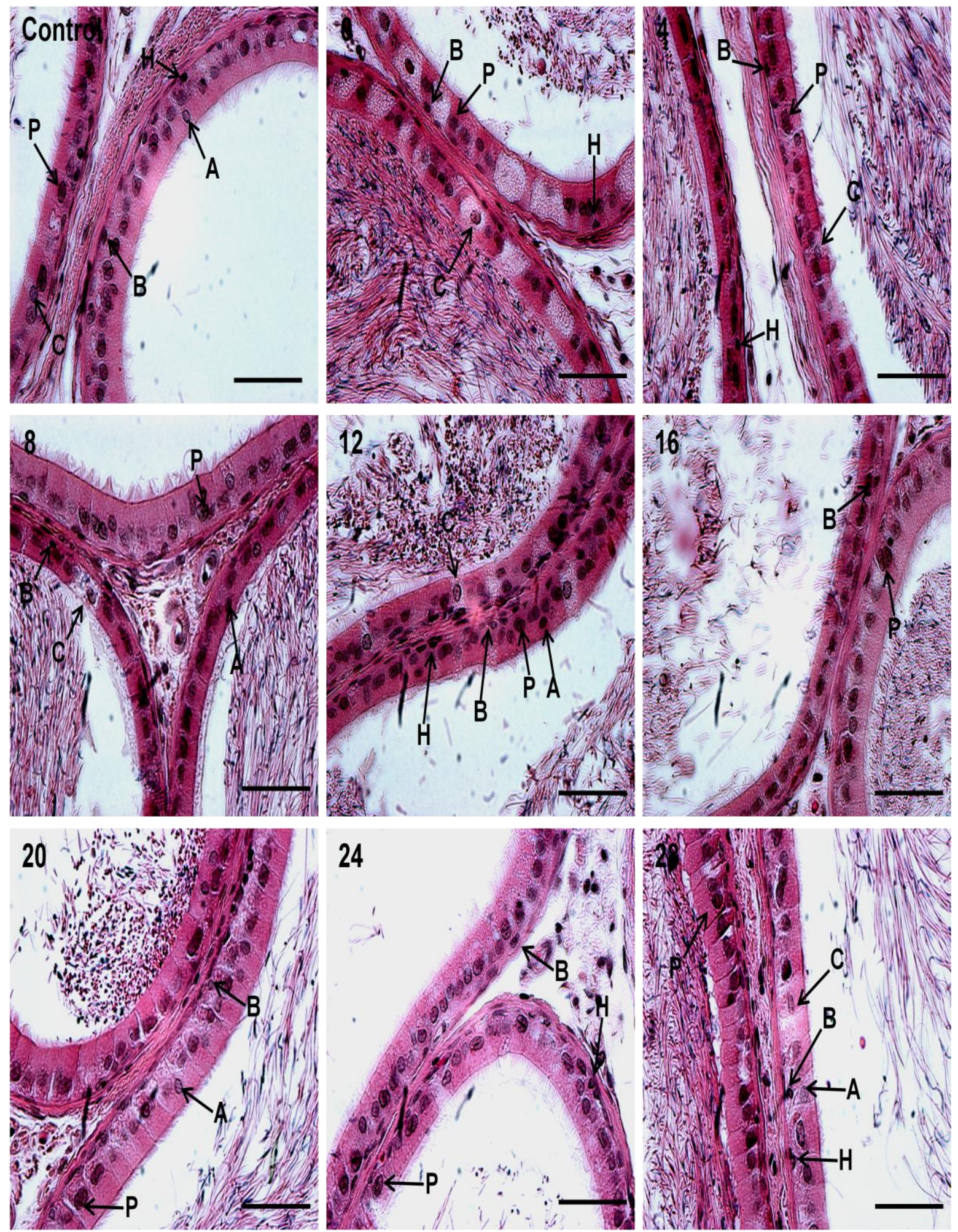

Figura 9. Microfotografía de cortes transversales de la cauda del epidídimo después de la saciedad sexual. Se nota la basofilia y acidofilia en los diferentes tipos celulares. Los números representan los días posteriores a la saciedad sexual y las letras representan los tipos celulares. P: principales, $\mathrm{B}$ : basales, A: apicales, C: claras y H: halo (H-E; barras y aumento original: $500 \mu \mathrm{m}$ y x400). 


\subsubsection{Análisis cuantitativo del epidídimo}

\subsubsection{Tipo celular}

Nos enfocamos en cinco tipos celulares: principales, claras, apicales, basales y halo de las tres regiones del epidídimo (cap, cor y cau) (Tabla 1 y 2).

A lo largo del conducto epididimario, el número de células principales, disminuyó significativamente $(P<0.05)$ en los días 0 al 16 en cap y en los días 0 al 20 en cor/cau. Las células claras, aumentaron significativamente $(P<0.05)$ el día 20 en cor (Tabla 1). Las células basales disminuyeron significativamente $(P<0.05)$ en cor los días 0 al 16, y en cau los días 4, 12 y 16 posteriores a la saciedad sexual. En cuanto a las células halo disminuyeron significativamente $(P<0.05)$ en el día 8 en cap, los días 0 al 28 en corlcau posteriores a la saciedad sexual (Tabla 2). 
Tabla 1. Tipo celular del tubo epididimario de las tres regiones (cap, cor y cau) en los días posteriores a la saciedad sexual.

\begin{tabular}{|c|c|c|c|c|c|c|c|c|c|}
\hline & \multicolumn{9}{|c|}{ TIPOCELULAR } \\
\hline & \multicolumn{3}{|c|}{ Principales } & \multicolumn{3}{|c|}{ Claras } & \multicolumn{3}{|c|}{ Apicales } \\
\hline & Caput & Corpus & Cauda & Caput & Corpus & Cauda & Caput & Corpus & Cauda \\
\hline Control & $56.33 \pm 4.63$ & $55.00 \pm 3.01$ & $65.56 \pm 5.94$ & $2.55 \pm 1.18$ & $0.88 \pm 0.35$ & $6.11 \pm 1.38$ & $4.22 \pm 1.19$ & $4.22 \pm 0.89$ & $4.22 \pm 1.02$ \\
\hline \multicolumn{10}{|c|}{$\begin{array}{l}\text { Día postsaciedad } \\
\text { sexual }\end{array}$} \\
\hline 0 & $34.33 \pm 2.01^{*}$ & $37.11 \pm 1.47^{*}$ & $37.22 \pm 0.98 *$ & $0.77 \pm 0.32$ & $1.11 \pm 0.30$ & $2.88 \pm 1.08$ & $4.00 \pm 1.02$ & $2.11 \pm 0.45$ & $3.66 \pm 0.66$ \\
\hline 4 & $38.89 \pm 1.24^{*}$ & $36.67 \pm 2.50^{*}$ & $37.44 \pm 1.86^{*}$ & $1.55 \pm 0.81$ & $0.77 \pm 0.27$ & $4.00 \pm 1.00$ & $4.55 \pm 1.23$ & $2.77 \pm 0.52$ & $2.44 \pm 0.66$ \\
\hline 8 & $41.56 \pm 1.74^{*}$ & $40.00 \pm 2.03^{*}$ & $41.33 \pm 1.65^{*}$ & $1.22 \pm 0.54$ & $1.00 \pm 0.37$ & $3.77 \pm 1.19$ & $4.55 \pm 1.04$ & $3.11 \pm 0.42$ & $2.55 \pm 0.41$ \\
\hline 12 & $37.44+1.46^{*}$ & $35.44 \pm 2.09^{*}$ & $35.33 \pm 2.17^{*}$ & $1.33 \pm 0.66$ & $1.22 \pm 0.43$ & $3.88 \pm 1.18$ & $4.11 \pm 1.45$ & $2.77 \pm 0.64$ & $2.44 \pm 0.62$ \\
\hline 16 & $35.89 \pm 1.64^{*}$ & $33.89 \pm 1.73^{*}$ & $36.22 \pm 2.57^{*}$ & $1.66 \pm 0.78$ & $1.44 \pm 0.17$ & $4.33 \pm 1.17$ & $5.44 \pm 1.84$ & $3.33 \pm 0.55$ & $2.44 \pm 0.62$ \\
\hline 20 & $53.11 \pm 3.71$ & $45.33 \pm 2.22^{*}$ & $44.22 \pm 3.07^{*}$ & $2.33 \pm 0.86$ & $2.44 \pm 0.53^{*}$ & $5.88 \pm 1.21$ & $4.33 \pm 1.00$ & $3.55 \pm 0.58$ & $3.33 \pm 0.89$ \\
\hline 24 & $50.67 \pm 3.01$ & $46.68 \pm 2.64$ & $55.78 \pm 2.97$ & $2.33 \pm 0.76$ & $1.55 \pm 0.55$ & $3.66 \pm 1.24$ & $4.66 \pm 0.95$ & $3.11 \pm 0.58$ & $3.66 \pm 0.72$ \\
\hline 28 & $53.22+4.65$ & $50.00 \pm 1.94$ & $53.00 \pm 3.06$ & $1.55 \pm 0.64$ & $0.88 \pm 0.35$ & $4.88 \pm 1.29$ & $5.88 \pm 1.64$ & $3.44 \pm 0.72$ & $2.44 \pm 1.14$ \\
\hline
\end{tabular}

Los datos se expresan en promedio \pm ee, $U$ Mann-Whitney, ${ }^{*} \mathrm{P}<0.05$. Control $=$ macho con una serie eyaculatoria. 
Tabla 2. Tipo celular del tubo epididimario de las tres regiones (cap, cor y cau) en los días posteriores a la saciedad sexual.

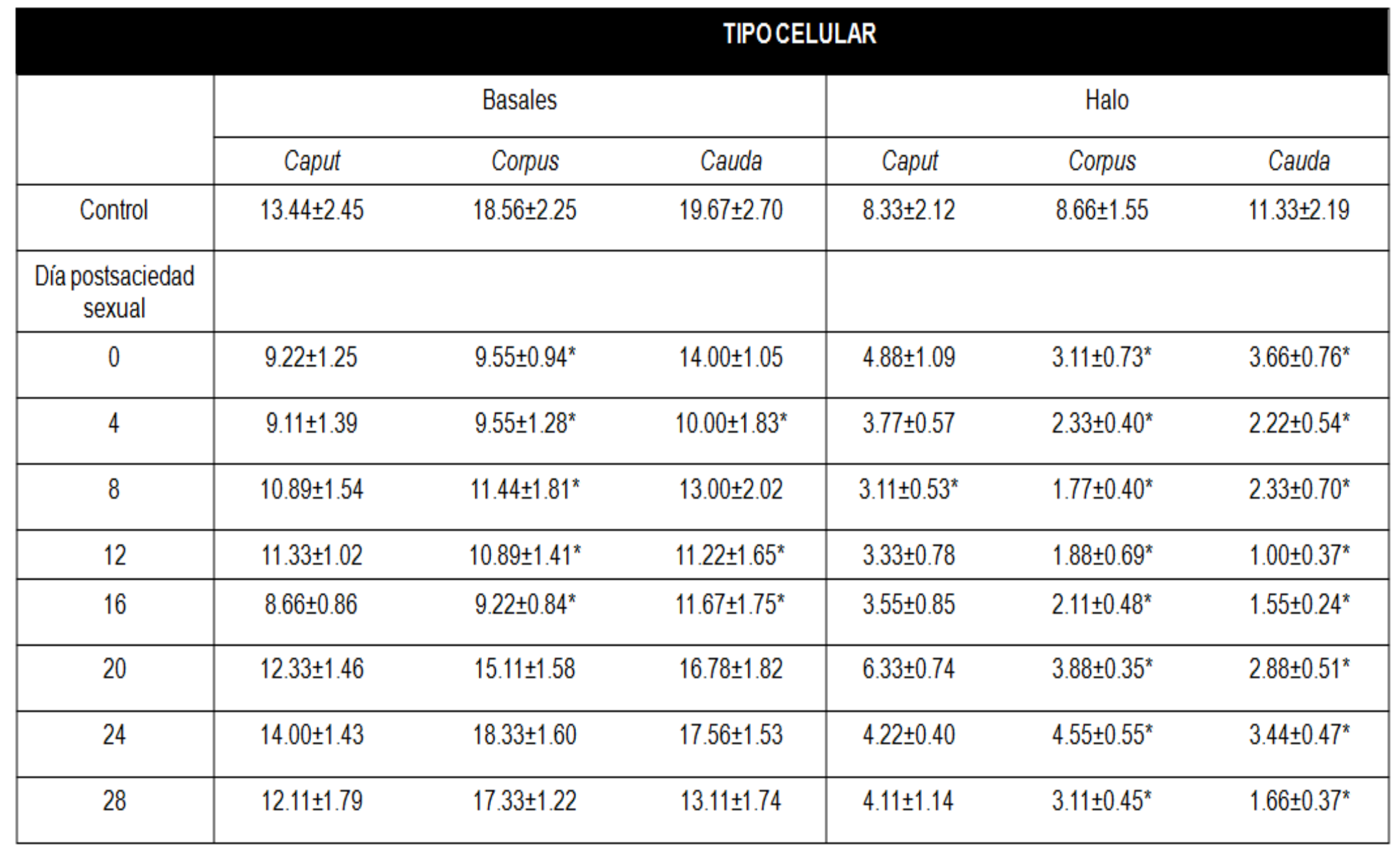

Los datos se expresan en promedio \pm ee, $U$ Mann-Whitney, ${ }^{*} \mathrm{P}<0.05$. Control $=$ macho con una serie eyaculatoria. 


\subsubsection{Tipo de epitelio}

En el grupo control se encontraron conductos epididimarios con diferentes tipos de epitelio: simple cilíndrico en cap/cau y simple cúbico mediano en cor. Con disminuciones significativas $(P<0.05)$ el día 8 en el cap (control $=90.00 \pm 9.64$ vs $45.00 \pm 7.23$ ) y 12 en la cau (control $=47.33 \pm 5.60$ vs $21.67 \pm 4.91$ ) (Tabla $3 A$ ). El tipo de epitelio encontrado postsaciedad sexual, es un epitelio simple cúbico mediano en el cap y simple cúbico bajo en el cor y cau. Con aumentos significativos $(\mathrm{P}<0.05)$ los días 12,16 y 24 en la cau, 8, 16 y 20 en el cap (Tabla 3B).

Tabla 3. Número de conductos epididimarios con diferentes tipos de epitelio en las tres regiones (cap, cor y cau) en los días posteriores a la saciedad sexual.

\begin{tabular}{|c|c|c|c|c|c|c|c|}
\hline \multirow[t]{3}{*}{ A } & \multicolumn{3}{|c|}{ TIPO DE EPITELLO } & B & \multicolumn{3}{|c|}{ TIPO DE EPITELLOO } \\
\hline & \multicolumn{2}{|c|}{ Simple cilíndrico } & \multirow{2}{*}{$\begin{array}{c}\begin{array}{c}\text { Simple cúbico } \\
\text { mediano }\end{array} \\
\text { Corpus }\end{array}$} & & \multicolumn{2}{|c|}{ Simple cúbico bajo } & \multirow{2}{*}{$\begin{array}{c}\begin{array}{c}\text { Simple cúbico } \\
\text { mediano }\end{array} \\
\text { Caput }\end{array}$} \\
\hline & Caput & Cauda & & & Copus & Cauda & \\
\hline Control & $90.00 \pm 9.64$ & $47.33 \pm 5.60$ & $58.00 \pm 0.11$ & Control & $21.00 \pm 8.88$ & $23.33 \pm 1.76$ & $8.00 \pm 4.61$ \\
\hline $\begin{array}{l}\text { Díapostsaciedad } \\
\text { sexual }\end{array}$ & & & & $\begin{array}{l}\text { Díapostsaciedad } \\
\text { sexual }\end{array}$ & & & \\
\hline 0 & $62.00 \pm 15.70$ & $47.33+5.48$ & $48.33 \pm 14.52$ & 0 & $49.67 \pm 21.67$ & $35.33 \pm 111.72$ & $42.67 \pm 17.70$ \\
\hline 4 & $64.33 \pm 13.04$ & $29.33 \pm 4.25$ & $34.33 \pm 6.88$ & 4 & $53.00 \pm 24.38$ & $48.00 \pm 6.24$ & $49.67 \pm 18.84$ \\
\hline 8 & $45.00 \pm 7.23^{*}$ & $31.00 \pm 8.50$ & $34.33 \pm 2.02$ & 8 & $69.33 \pm 20.08$ & $68.67 \pm 14.62$ & $57.33+9.68^{*}$ \\
\hline 12 & $65.67 \pm 28.42$ & $21.67 \pm 4.91^{*}$ & $35.00 \pm 5.68$ & 12 & $43.33 \pm 15.17$ & $51.67 \pm 5.78^{*}$ & $55.00 \pm 13.61$ \\
\hline 16 & $44.00 \pm 13.00$ & $29.33 \pm 3.28$ & $29.67 \pm 11.20$ & 16 & $52.67 \pm 9.17$ & $55.67 \pm 6.56^{*}$ & $54.67 \pm 8.09^{*}$ \\
\hline 20 & $53.33 \pm 15.17$ & $45.00 \pm 6.65$ & $42.00 \pm 3.21$ & 20 & $33.00 \pm 3.05$ & $42.00 \pm 8.08$ & $42.00 \pm 5.68^{*}$ \\
\hline 24 & $61.00 \pm 14.84$ & $45.00 \pm 3.78$ & $56.33 \pm 6.36$ & 24 & $27.33+3.84$ & $38.33 \pm 11.57^{\star}$ & $31.33 \pm 6.33$ \\
\hline 28 & $55.00 \pm 0.80$ & $47.00 \pm 6.24$ & $52.00 \pm 9.01$ & 28 & $33.00 \pm 7.00$ & $38.67 \pm 2.02$ & $38.67 \pm 6.00$ \\
\hline
\end{tabular}

Los datos se expresan en promedio \pm ee, ANOVA, Tukey-Kramer $\left.{ }^{*} \mathrm{P}<0.05\right)$. Control= macho con una serie eyaculatoria. 
El tipo de epitelio que se encontró en las tres regiones del epidídimo en los animales controles varia por región, encontrándose en diferentes proporciones en los días posteriores a la saciedad sexual (Tabla 3). En el cap y la cau se encuentra un epitelio simple cilíndrico que en los días posteriores a la saciedad sexual disminuye, encontrando epitelio simple cúbico mediano. En el cor se encontró epitelio simple cúbico mediano en el control, con tendencia a disminuir en los días posteriores a la saciedad sexual encontrando epitelio simple cúbico bajo. En suma se aprecia que en el mismo periodo de tiempo entre 8 y 16 días de reposo postsaciedad varía el epitelio de simple cilíndrico a simple cúbico, así como de simple cúbico mediano a simple cúbico bajo.

\subsubsection{Morfometría}

En las tres regiones del epidídimo (cap, cor y cau) se observó tendencia al aumento en el área luminal libre de espermatozoides en los días $0,4,12$ y 16 en el cap, 0-16 en el cor y la cau posterior a la saciedad sexual (Fig. 10-12A) y para corroborar lo anterior se midieron: área luminal total, área del aglomerado de espermatozoides, área luminal libre de espermatozoides (Figs. 10-12B), área del epitelio y la altura del epitelio (Figs. 13-14).

En la región del cap, el área luminal total aumentó significativamente $(P<0.05)$ en los días 8 y 16 (Control=54890 \pm 3337 vs $77250 \pm 5052,64480 \pm 3521 \mu \mathrm{m}^{2}$ ). También aumentó $(\mathrm{P}<0.05)$ en el día 8 el área del aglomerado de espermatozoides y disminuyó $(\mathrm{P}<0.05)$ en el día 12 (Control=38920 \pm 2668 vs $52270 \pm 3811,27330 \pm 2713$ $\left.\mu \mathrm{m}^{2}\right)$. El área luminal libre de espermatozoides aumentó $(\mathrm{P}<0.05)$ en el día 8 (Control=15970 $\pm 1003,24980 \pm 2182 \mu \mathrm{m}^{2}$ ) (Fig. 10B).

En la región del cor se observó que el área luminal total aumentó $(P<0.05)$ en los días 8 y 16 (Control=59130 \pm 1537 vs $66440 \pm 1921,69130 \pm 2687 \mu m^{2}$ ), sin embargo, en el área del aglomerado de espermatozoides no se observaron diferencias. En cuanto al área luminal libre de espermatozoides aumentó $(P<0.05)$ en los días 8 y 16 (Control=18050 \pm 744.3 vs $23960 \pm 1277,24740 \pm 1140 \mu m^{2}$ ) (Fig. 11B). 
En la región de la cau se observó que el área luminal total disminuyó $(P<0.05)$ en el día 0 (Control=71400 \pm 5697 vs $52910 \pm 2775 \mu \mathrm{m}^{2}$ ), con lo anterior también disminuyó $(\mathrm{P}<0.05)$ el área del aglomerado de espermatozoides en el día 0 (Control $=47930 \pm 4724$ vs $28740 \pm 2233 \mu \mathrm{m}^{2}$ ). Sin embargo, en cuanto al área luminal libre de espermatozoides no se observaron diferencias (Fig. 12B).

En cuanto al área del epitelio disminuyó $(\mathrm{P}<0.05)$ en el día 12 en el cap (Control $=25990 \pm 774.5$ vs $\left.22500 \pm 1046 \mu \mathrm{m}^{2}\right)$, en los días 20 y 24 aumentó $(P<0.05)$ en el cor (Control=20190 \pm 462.5 vs $22250 \pm 623.2,225510 \pm 553.6 \mu \mathrm{m}^{2}$ ) y en los días 0 aumentó, 8 y 20 disminuyó $(\mathrm{P}<0.05)$ en la cau (Control=26730 \pm 2153 vs $27190 \pm 808.8,21190 \pm 466.1,22110 \pm 935.3 \mu \mathrm{m}^{2}$ ) (Fig. 13).

La altura del tubo epididimario disminuyó significativamente $(\mathrm{P}<0.05)$ en los días 0 al 28 en el cap (Control=30.96 \pm 0.34 vs $26.82 \pm 0.31,28.38 \pm 0.39,26.43 \pm 0.38$, $29.37 \pm 0.45,26.74 \pm 0.33,26.46 \pm 0.25,25.96 \pm 0.34,27.89 \pm 0.31 \mu \mathrm{m})$, en el cor aumentó los días 4,12 al 28 (Control=22.64 \pm 0.25 vs $24.09 \pm 0.33,23.67 \pm 0.28,23.89 \pm 0.34$, $25.35 \pm 0.33,25.08 \pm 0.29,23.68 \pm 0.27 \mu \mathrm{m})$ y en la cau también aumentó en el día 0 (Control $=26.32 \pm 0.53$ vs $28.53 \pm 0.39 \mu \mathrm{m})$ y disminuyó $(\mathrm{P}<0.05)$ en los días 4 al 28 (Control=26.32 \pm 0.53 vs $23.24 \pm 0.36, \quad 22.04 \pm 0.27, \quad 22.32 \pm 0.40, \quad 20.82 \pm 0.27$, $20.80 \pm 0.29,22.90 \pm 0.37,22.29 \pm 0.38 \mu \mathrm{m})$ (Fig. 14). 

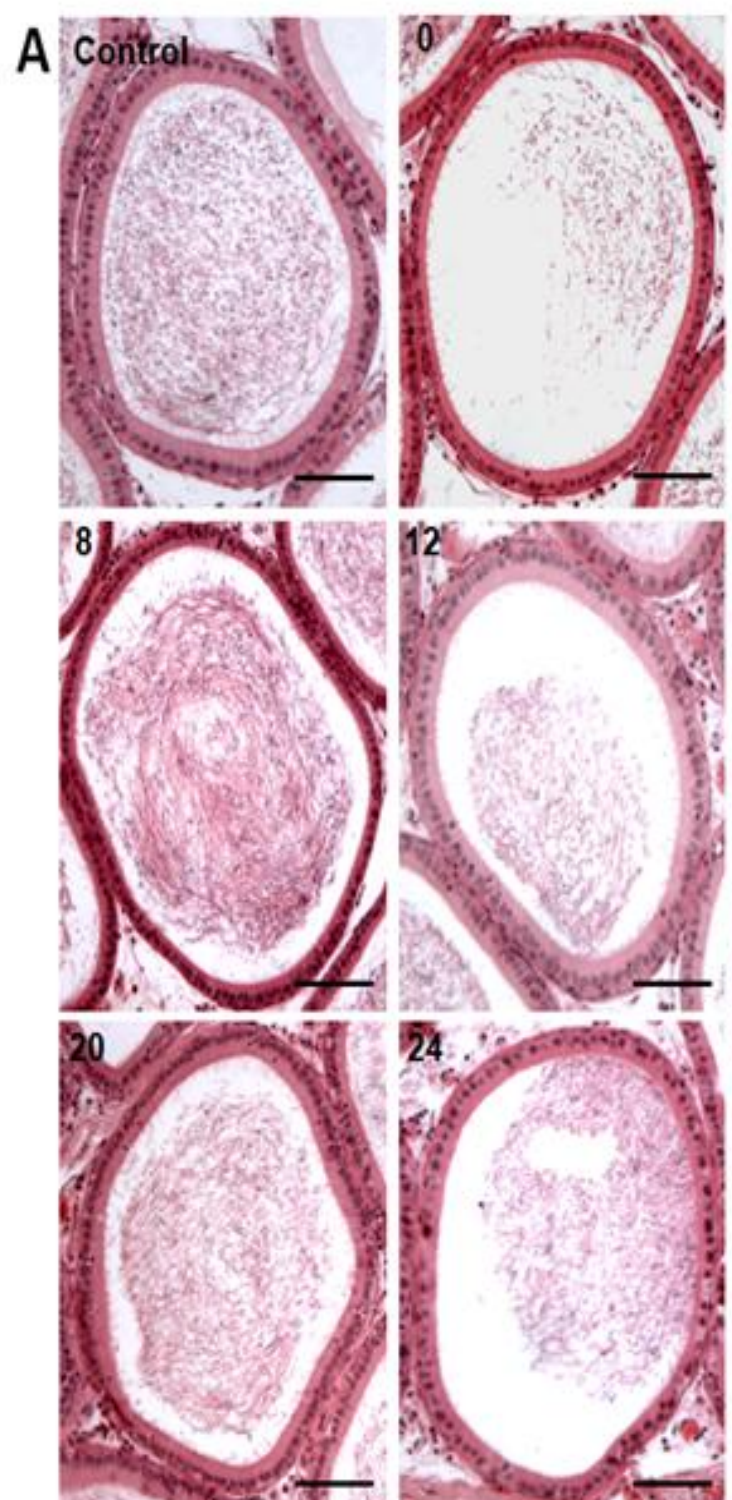
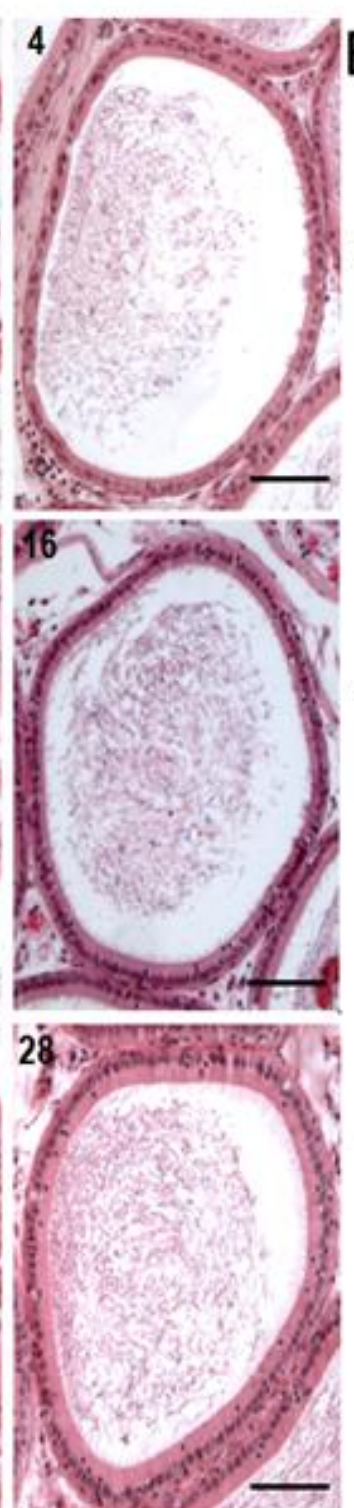
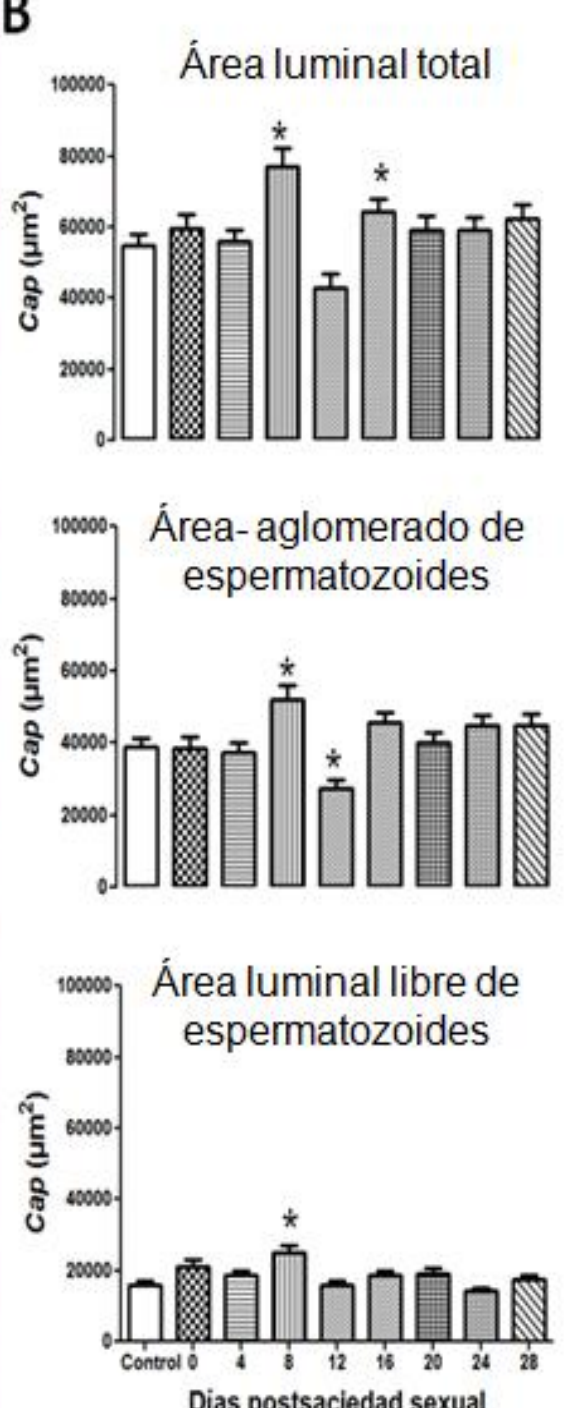

Figura 10. Región del cap del tubo epididimario de rata Wistar, en los días posteriores a la saciedad sexual. A) Microfotografías de cortes transversales, los números indican los días después de la saciedad sexual (H-E, barras y aumento original: $100 \mu \mathrm{m}$ y x100) B) Mediciones de las áreas: luminal total, aglomerado

espermatozoides y luminal libre de espermatozoides. Los datos se expresan en promedio \pm ee, U MannWhitney, ${ }^{*} \mathrm{P}<0.05$. 

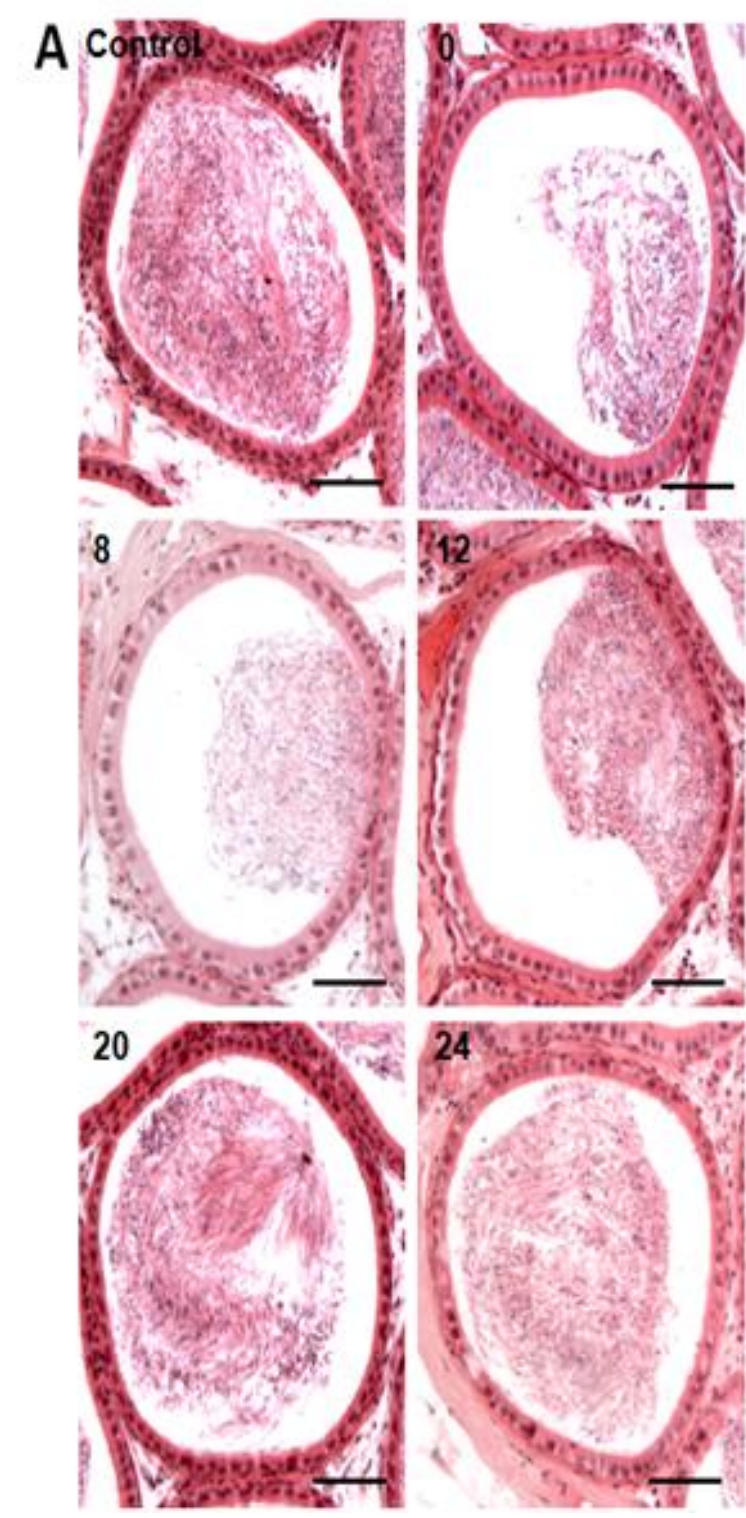
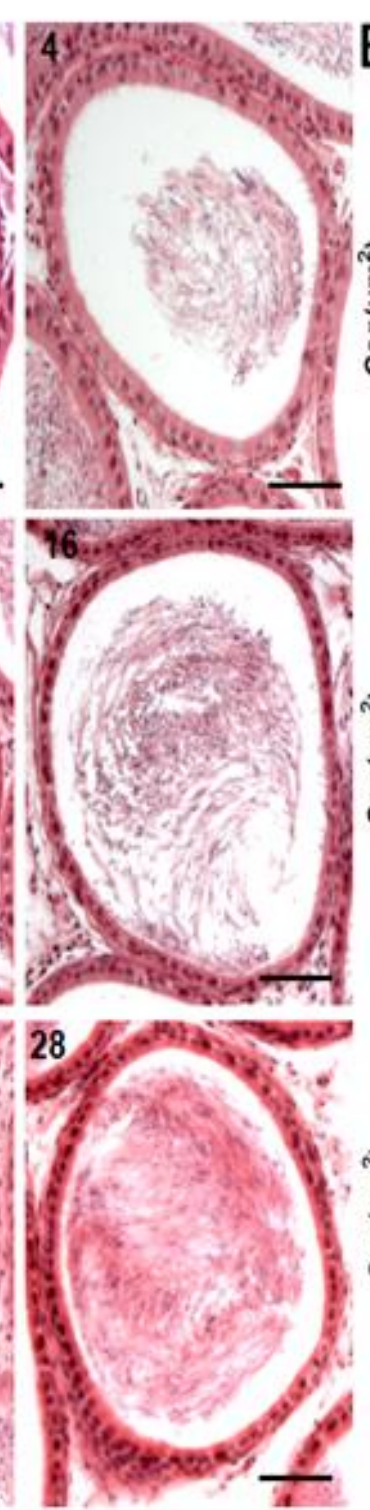

B
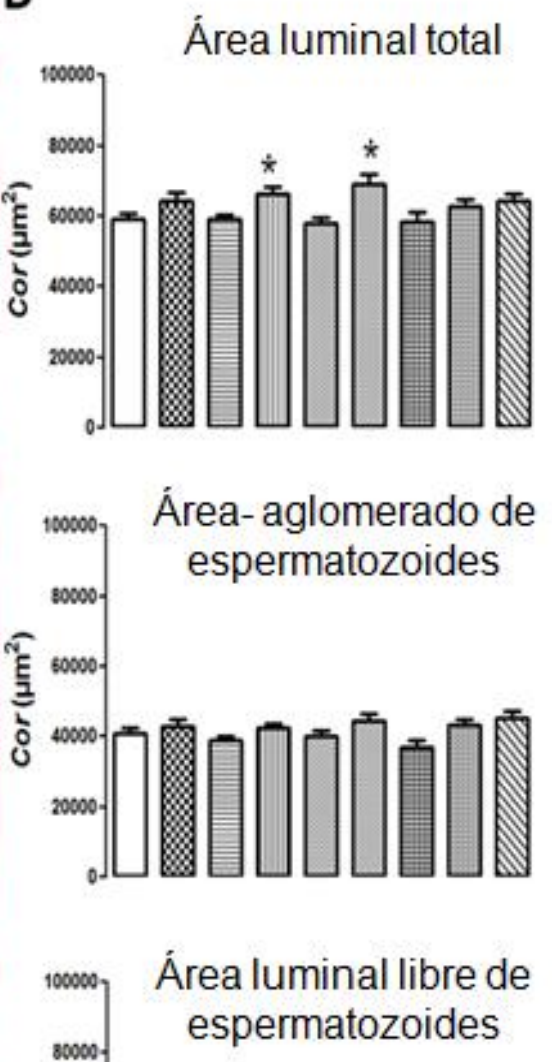

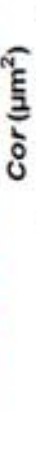

\begin{abstract}
espermatozoides
\end{abstract}
Figura 11. Región del cor del tubo epididimario de rata Wistar, en los días posteriores a la saciedad sexual. A) Microfotografías de cortes transversales, los números indican los días después de la saciedad sexual $(\mathrm{H}-\mathrm{E}$, barras $\mathrm{y}$ aumento original: $100 \mu \mathrm{m} y$ x100) B) Mediciones de las áreas: luminal total, aglomerado

espermatozoides y luminal libre de espermatozoides. Los datos se expresan en promedio \pm ee, U MannWhitney, ${ }^{*} \mathrm{P}<0.05$. 

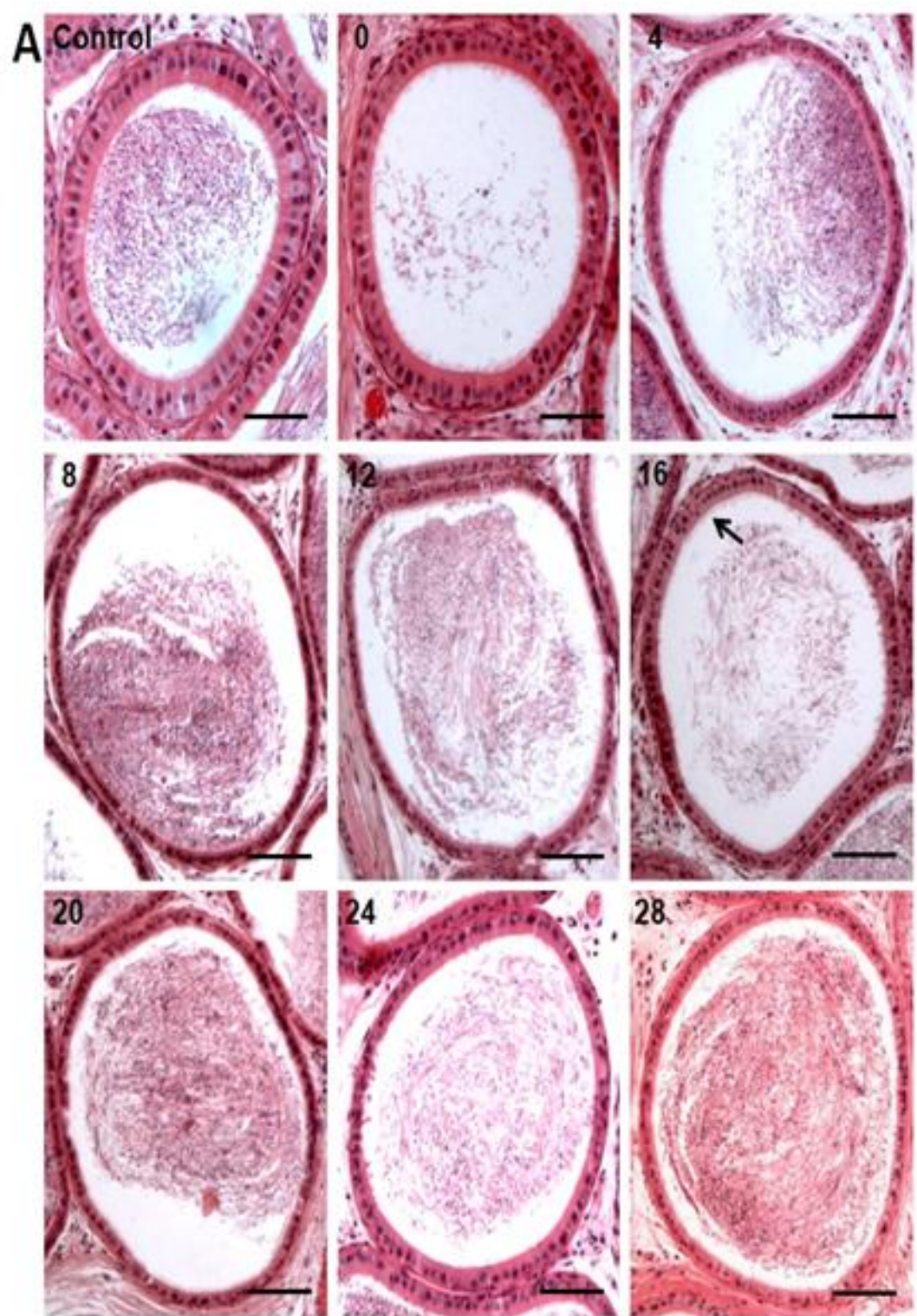
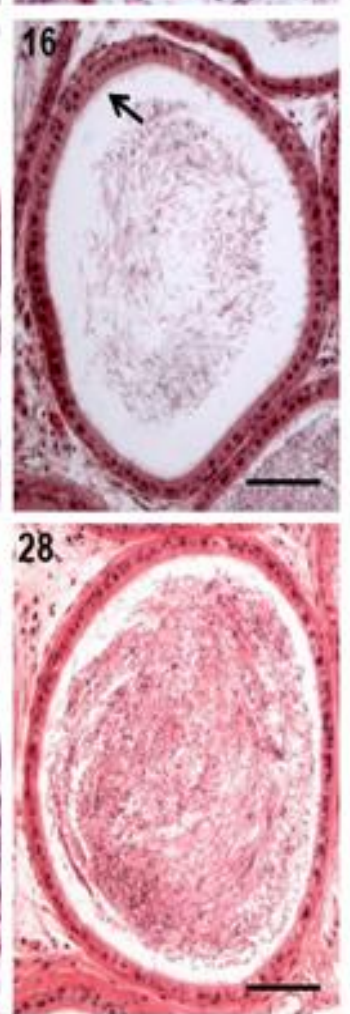

\section{B}
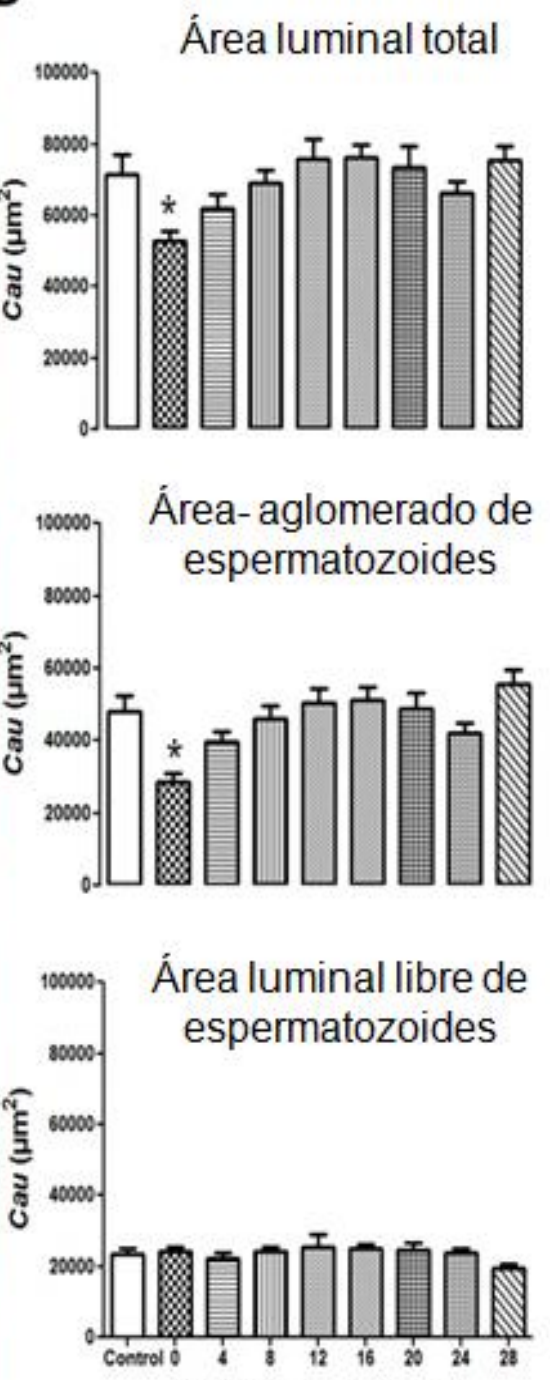

Dias postsaciedad sexual
Figura 12. Región de la cau del tubo epididimario de rata Wistar, en los días posteriores a la saciedad sexual. A) Microfotografías de cortes transversales, los números indican los días después de la saciedad sexual $(\mathrm{H}-\mathrm{E}$, barras $\mathrm{y}$ aumento original: $100 \mu \mathrm{m}$ y $x 100)$ B) Mediciones de las áreas: luminal total, aglomerado

espermatozoides y luminal libre de espermatozoides. Los datos se expresan en promedio \pm ee, $\cup$ MannWhitney, ${ }^{*} \mathrm{P}<0.05$. 

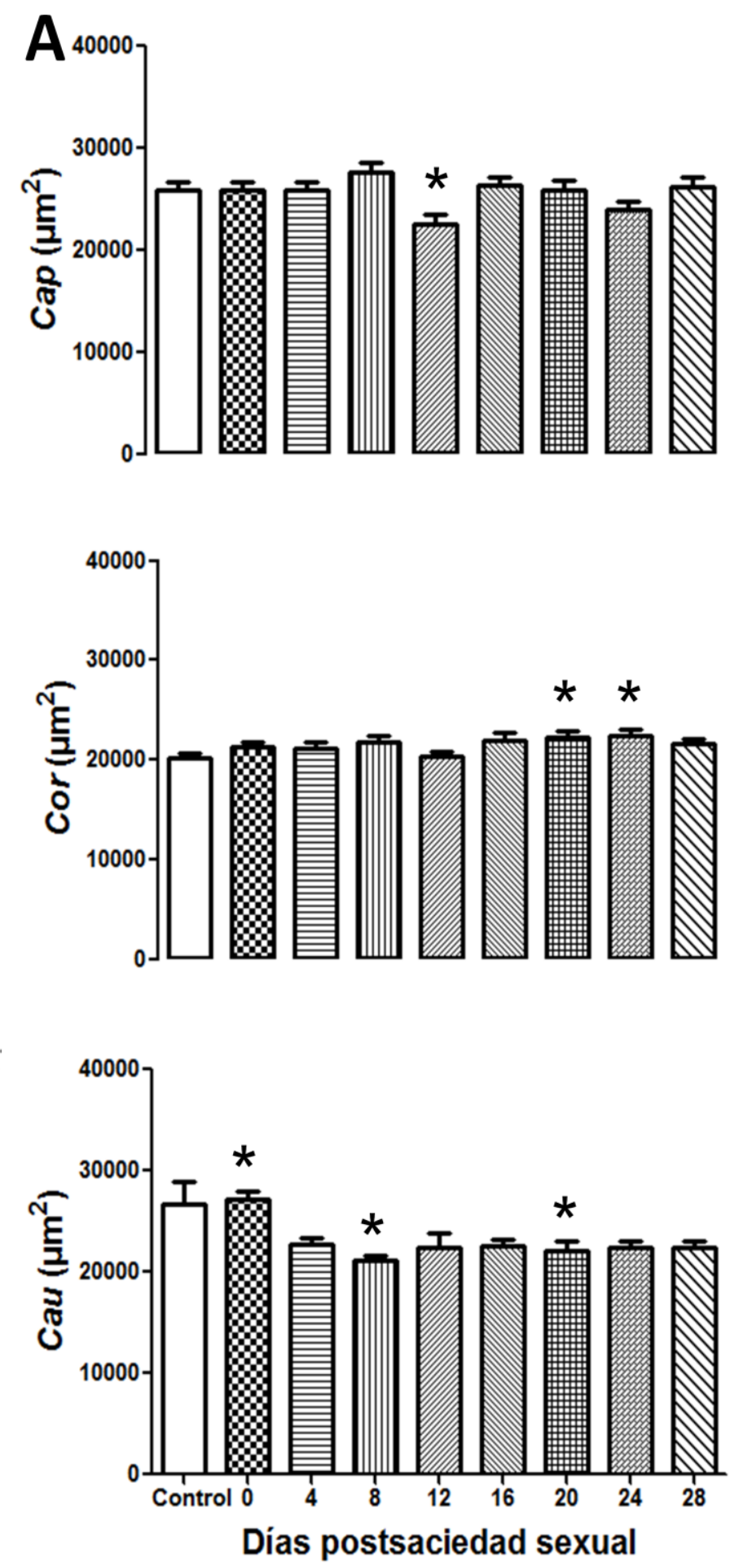

Figura 13. Mediciones del área del epitelio del tubo epididimario de las tres regiones (cap, cor y cau) de rata Wistar en los días posteriores a la saciedad sexual. Los datos se expresan en promedio \pm ee, $U$ Mann-Whitney, ${ }^{*} \mathrm{P}<0.05$. 

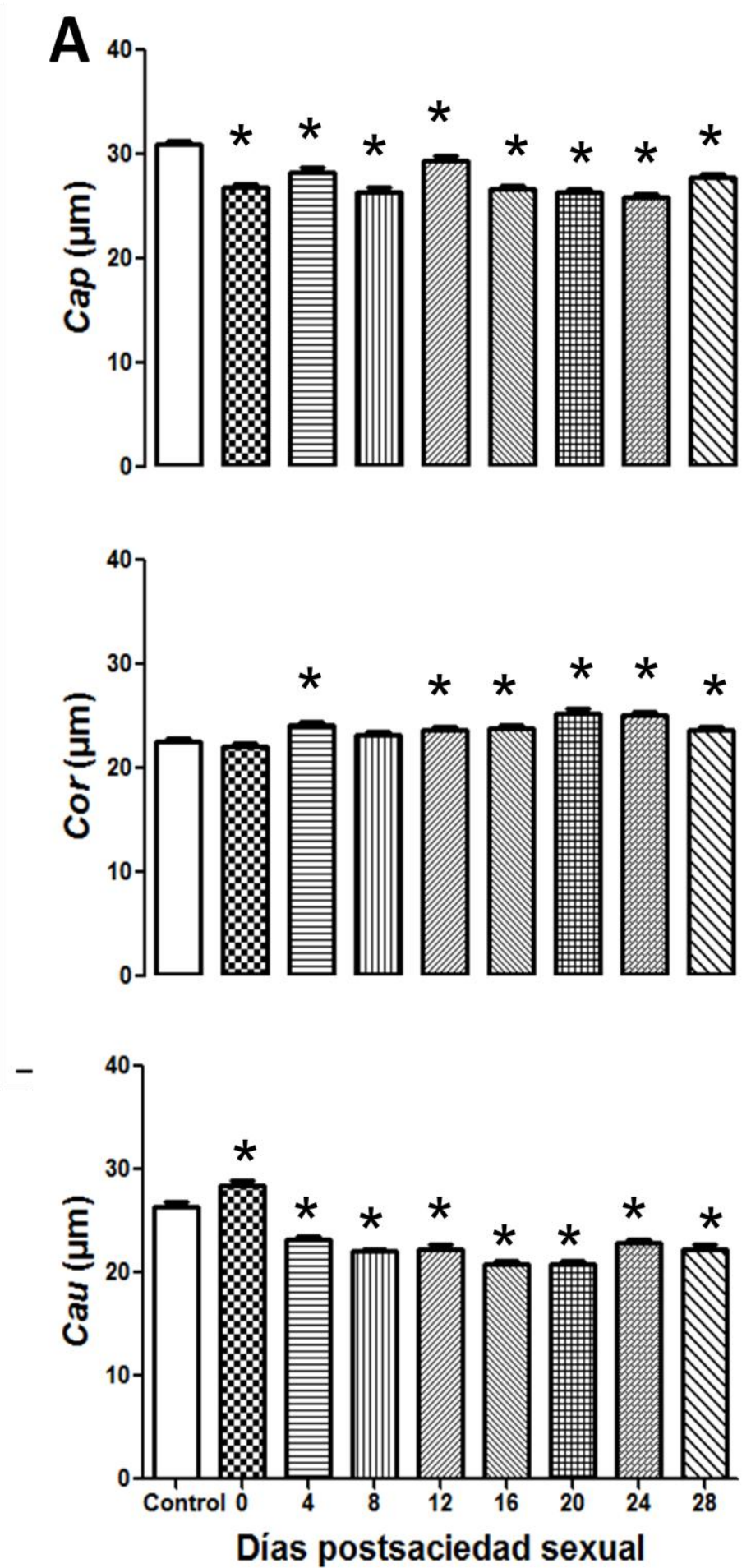

Figura 14. Mediciones de la altura del tubo epididimario de las tres regiones (cap, cor y cau) de rata Wistar en los días posteriores a la saciedad sexual. Los datos se expresan en (promedio \pm ee) (U Mann-Whitney, $\left.{ }^{*} \mathrm{P}<0.05\right)$. 


\subsection{Parámetros espermáticos del epidídimo}

\subsubsection{Concentración espermática}

En las tres regiones del epidídimo hay una disminución en la concentración en los días posteriores de la saciedad sexual (Fig. 15).

Se observan disminuciones significativas $(P<0.05)$ en la concentración espermática en: el día 0 (control $=2.85 \times 10^{8} \pm 1.801 \times 10^{9}$ vs $4.625 \times 10^{7} \pm 1.442 \times 10^{7}$ ) (Fig. 15: cap), el día 16 (control $=4.5 \times 10^{7} \pm 1.561 \times 10^{7}$ vs $3 \times 10^{6} \pm 1.155 \times 10^{6}$ ) (Fig. 15: cor) y los días $0,4,8$ y 16 (control $=4.875 \times 10^{8} \pm 2.102 \times 10^{8}$ vs $2.675 \times 10^{7} \pm 1.209 \times 10^{7}$, $7.625 \times 10^{7} \pm 1.85 \times 10^{7}, 7.125 \times 10^{7} \pm 2.818 \times 10^{7}, 6.375 \times 10^{7} \pm 1.092 \times 10^{7}$ ) (Fig. 15: cau). 

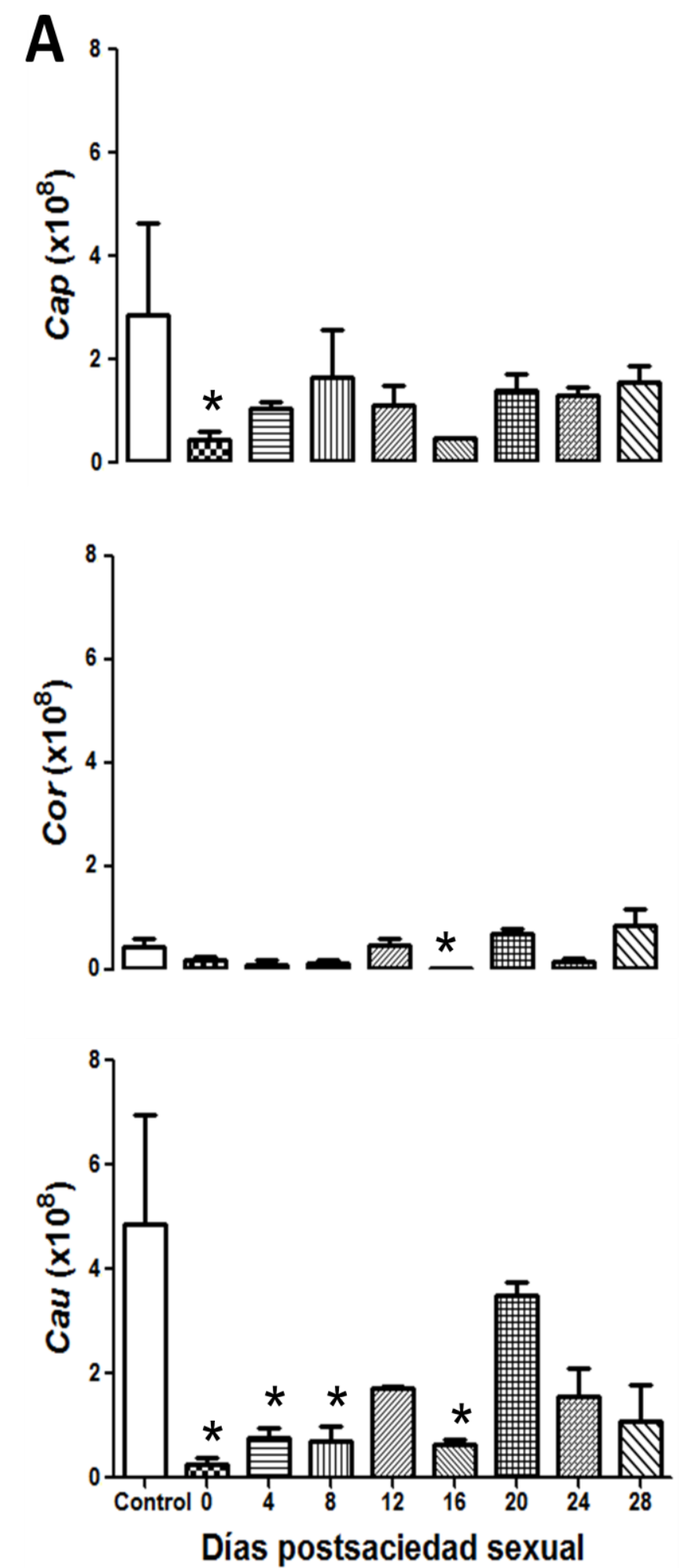

Figura 15. Concentración espermática en las tres regiones del epidídimo (cap, cor y cau). Los datos se expresan en promedio \pm ee, ANOVA, Tukey-Kramer ${ }^{*} \mathrm{P}<0.05, \mathrm{n}=3$. 


\subsubsection{Viabilidad espermática}

La viabilidad espermática se determinó con eosina-nigrosina, los espermatozoides vivos se muestran transparentes (Fig. 16A), mientras que los muertos se encuentran teñidos (Fig. 16B). El porcentaje de espermatozoides vivos en las tres regiones del epidídimo disminuyó significativamente $(\mathrm{P}<0.05)$ en los días 0 al 16 postsaciedad sexual en las regiones del cap (Control=67.67 \pm 2.90 vs $13.00 \pm 2.08,31.00 \pm 1.73$, $23.00 \pm 3.51$, $30.33 \pm 0.88,21.00 \pm 4.58$ ), cor (Control $=74.00 \pm 6.42$ vs $13.00 \pm 1.00$, $16.33 \pm 9.77,18.67 \pm 6.17,28.33 \pm 1.45,18.00 \pm 10.41$ ) y cau (Control $=71.33 \pm 3.33$ vs $15.33 \pm 1.45,26.00 \pm 1.52,23.00 \pm 8.18,19.33 \pm 3.75,28.33 \pm 3.18)$ (Fig. 17).

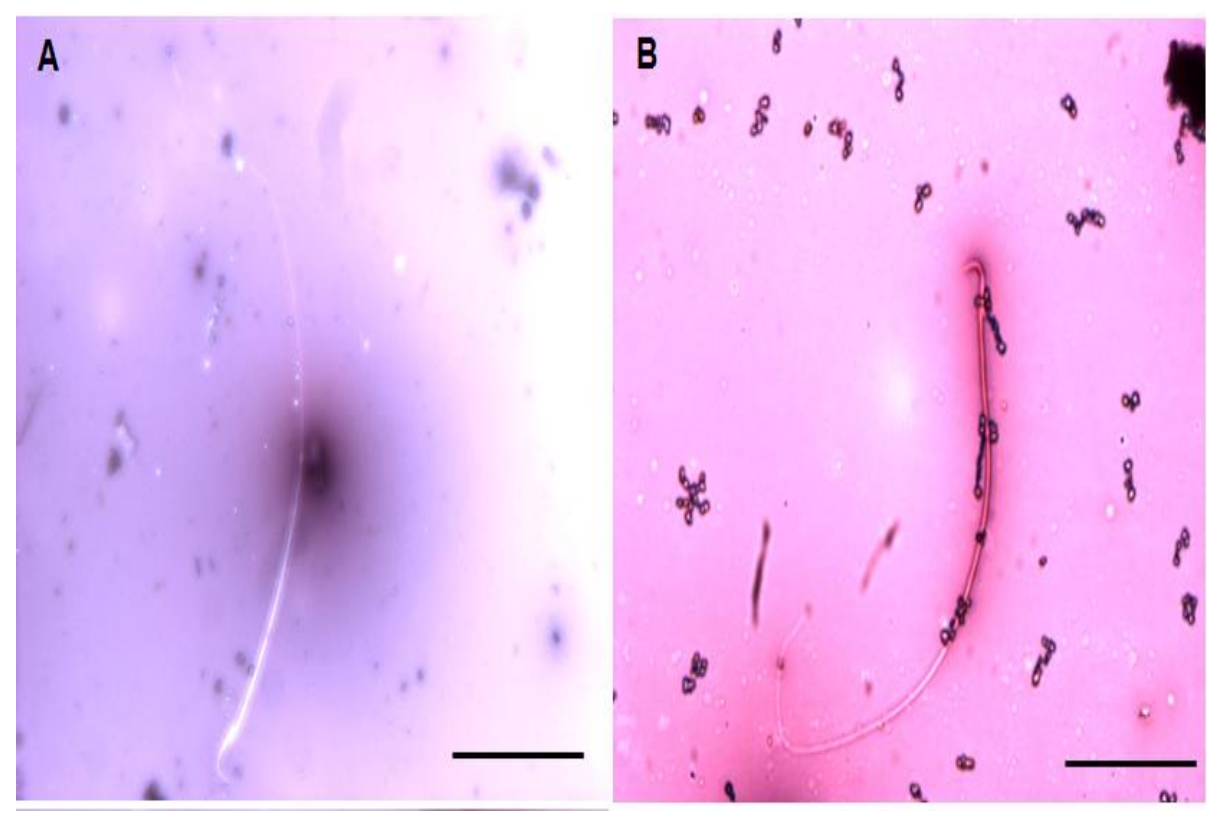

Figura. 16. Microfotografías de espermatozoides. Vivos: A, muertos: B. De las tres regiones del epidídimo (Eosina-Nigrosina; barras y aumento original: $500 \mu \mathrm{m}$ y x400). 

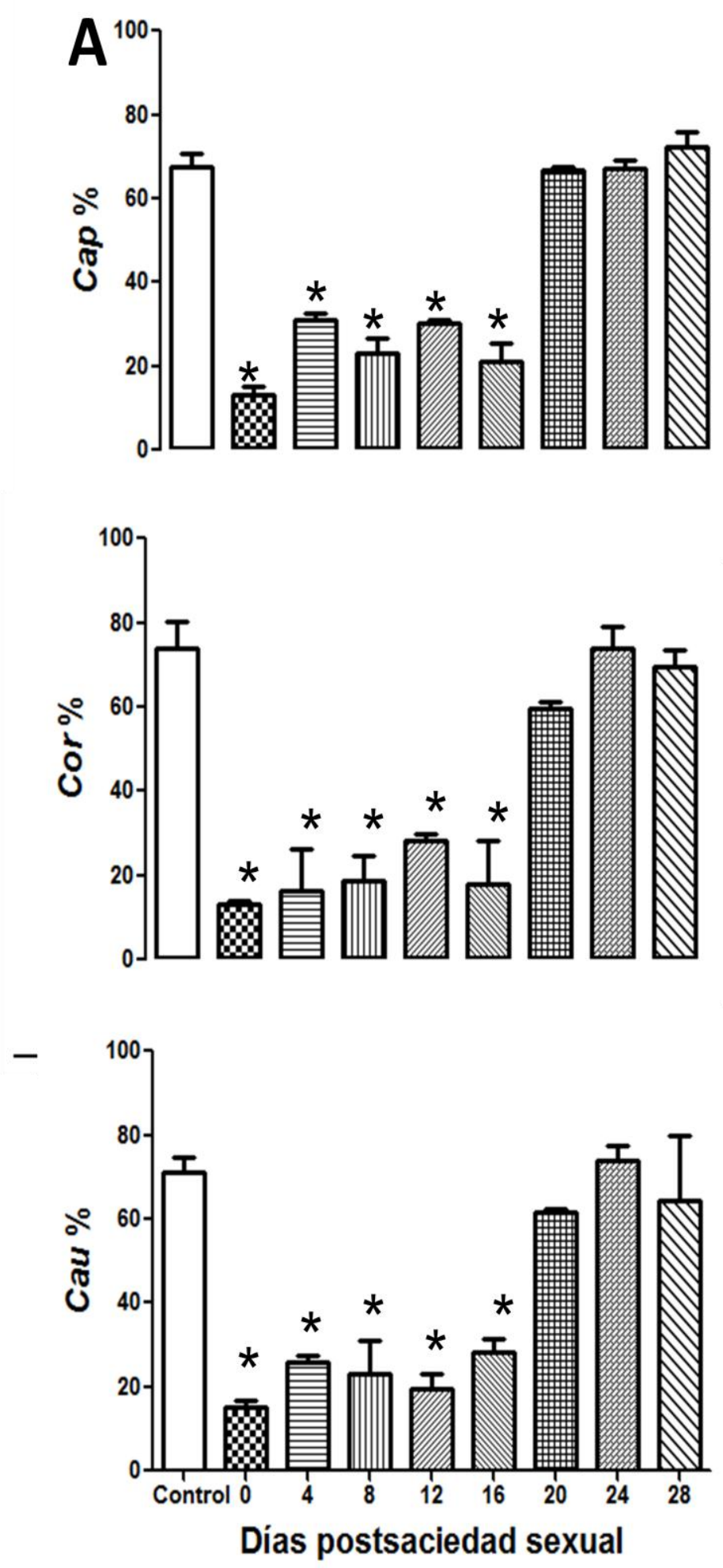

Figura 17. Porcentaje de espermatozoides vivos en las tres regiones del epidídimo (cap, cor y cau). Los datos se expresan en promedio \pm ee, ANOVA, Tukey-Kramer ${ }^{*} \mathrm{P}<0.05, \mathrm{n}=3$. 


\subsubsection{Morfología espermática}

El conteo de células con anormalidades morfológicas se hizo considerando la cabeza, pieza media, flagelo de los espermatozoides e incluyó la presencia de gota citoplasmática (Fig. 18).

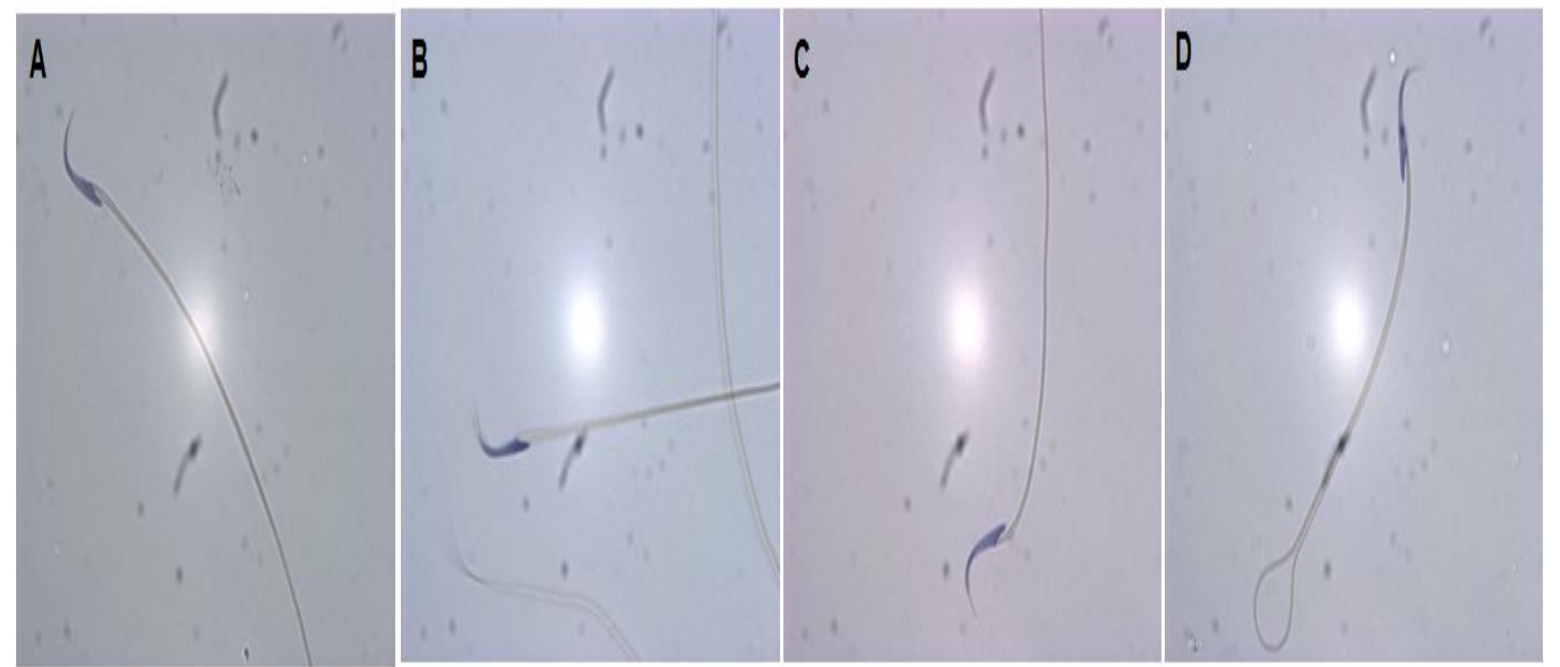

Figura. 18. Microfotografías de espermatozoides anormales en las tres regiones del epidídimo. A: normal, B: cabeza, C: pieza media y D: flagelo. (Tinción-Papanicolaou).

En las tres regiones del epidídimo (cap, cor y cau) hubo disminuciones significativas $(P<0.05)$ en el porcentaje de espermatozoides normales en los días 4 al 16 postsaciedad sexual en la región del cap (Control=54.33 \pm 3.38 vs $33.33 \pm 5.69$, $19.00 \pm 3.46,26.00 \pm 1.52,26.00 \pm 3.60)$ y cau $(65.33 \pm 6.48$ vs $30.67 \pm 5.17,29.33 \pm 3.75$, $35.33 \pm 7.05,34.00 \pm 4.16$ ) (Figura 19) y en los días 4 , 8 y 16 postsaciedad sexual en el cor (Control=60.33 \pm 2.90 vs $20.00 \pm 6.35,27.00 \pm 7.02,24.00 \pm 8.50$ ) (Figura 19). 

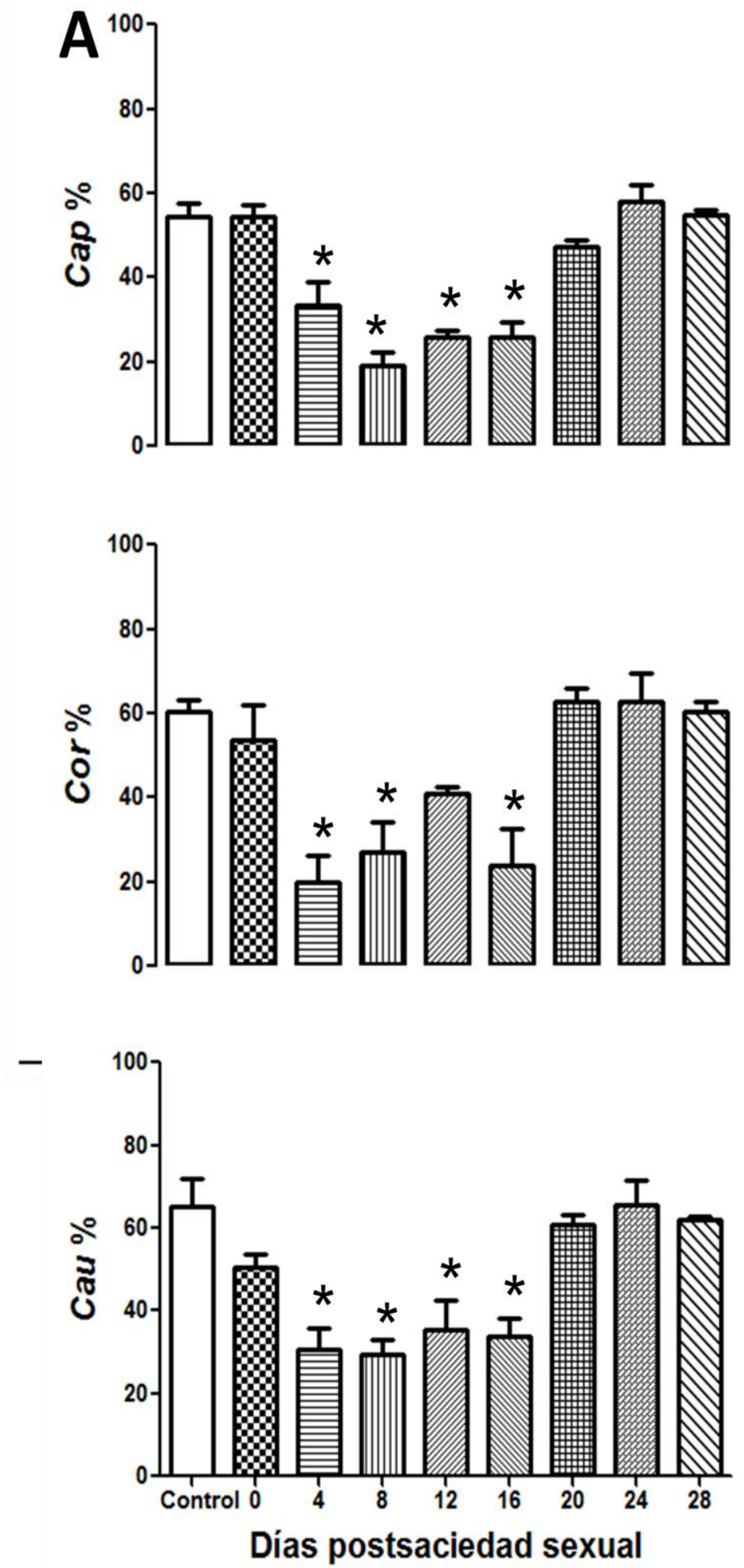

Figura 19. Porcentaje de espermatozoides con morfología normal en las tres regiones del epidídimo (cap, cor y cau). Los datos se expresan en(promedio $\pm e e$, ANOVA, Tukey-Kramer ${ }^{*} \mathrm{P}<0.05, \mathrm{n}=3$. 


\section{DISCUSIÓN}

\subsection{Peso del epidídimo}

El peso del epidídimo depende de factores hormonales y de elementos estructurales (Brooks, 1983; Sullivan y cols., 2007; Setchell y cols., 1994; Cornwall, 2009). Puede verse afectado cuando se le priva de andrógenos. Dadhich y cols., (2013) aportaron información relevante en este sentido al estudiar la actividad reproductiva en el topo Talpa occidentalis. Observaron que los testículos y epidídimos de machos sexualmente inactivos están reducidos respecto a los observados en época reproductiva. Lo cual lo asocian con una reducción de RA intratesticulares, T sérica e intratesticular. Esto contrasta con el aumento en el peso del epidídimo posteriores de la saciedad sexual (Figs. 5 A, B y D). El aumento observado en el día 0 , posiblemente se deba al efecto inicial del aumento de $T$ en suero que está asociado con la saciedad sexual, este aumento de $\mathrm{T}$ disminuye a niveles basales $24 \mathrm{~h}$ posteriores a la saciedad sexual y se mantuvo hasta los 7 días (Bonilla-Jaime y cols., 2006; Romano-Torres y cols., 2006). Al regresar a los niveles basales de T, el aumento significativo del peso epididimario quizá se deba al fluido testicular (incluyendo espermatozoides) propio de una espermatogénesis, que al parecer continúa normalmente (condición que deberá comprobarse con el análisis de las gónadas de los ejemplares de este diseño experimental). Esto representa la evidencia de que el peso del epidídimo es dependiente de la acción androgénica y del fluido espermático proveniente del testículo.

Otras razones del aumento en el peso del epidídimo, posiblemente se deba: a la deficiencia de aromatasa que provoca una hiperplasia, probablemente al exceso de andrógenos circulantes o bien un aumento de los receptores a estrógeno alfa (REa) que están implicados en la inflamación crónica (Vicenzo, 2016). También a que la BHE se vea comprometida por alguna lesión (Gregory y Cry, 2014) o disminución de $\mathrm{T}$ y esto provoque que las uniones herméticas se vean comprometidas y suceda un edema o un infiltrado. 
Por otro lado, Judd y cols., (1997) analizaron varios parámetros para la producción de espermatozoides después de la vasectomía unilateral, entre ellos, el peso del epidídimo. Encontraron que el peso no varió entre animales intactos y con vasectomía unilateral. En un estudio previo, Tlachi-López y cols., (2012) no encontraron cambios en el peso de la cau epididimaria de los animales sexualmente saciados (control $=232.7 \pm 8.7,249.2 \pm 8.7$ ). Lo anterior es constante en los pesos totales de los primeros días 0-4 y en los últimos días 20-28, en cap 4, 20-28 días, cor 0, 8-28 días y cau 0-12, 20-28 días.

\subsection{Histología del epidídimo}

\subsubsection{Análisis cualitativo del epidídimo}

El análisis cualitativo mostró que la basofilia nuclear cambia de eucromasia a heterocromasia, de ligera a intensa en los diferentes tipos celulares (principales, claras, basales, apicales y halo). Si la basofilia es tenue, característica de un núcleo eucromático, es indicador de que los componentes que se tiñen (cromosomas) no están compactados, es decir, presentan su cromatina laxa y por tanto, se considera un núcleo activo, ya que la cromatina laxa permite la actividad de las enzimas encargadas de la transcripción del ácido ribonucleico (ARN). Por otro lado, el citoplasma muestra pequeñas regiones con ligera basofilia, que se asocia a la presencia de retículo endoplásmico rugoso así como áreas con neutrofilia característica de la zona ocupada por el aparato de Golgi. La anterior citología corresponde a la de células con actividad de síntesis proteica y de secreción (Ross y Pawlina, 2016; Robaire y cols., 2006).

A su vez, la basofilia intensa indica que los cromosomas de composición química ácida están compactados. Si las células presentan núcleo heterocromático, la transcripción se encuentra disminuida por lo cual el núcleo de estas células se considera inactivo. Además si el citoplasma no muestra zonas basófilas ni neutrófilas que se asocian con retículo endoplásmico rugoso y aparato de Golgi, respectivamente, la citología presente es característica de una célula poco activa o 
inactiva en cuanto a síntesis proteica y actividad secretora (Ross y Pawlina, 2016; Robaire y cols., 2006).

Se ha documentado que después de la orquidectomía, la función secretora de las células principales se modifica por la virtual desaparición del retículo endoplásmico de su citoplasma apical, así como la pérdida de microvellosidades apicales, acumulación de lisosomas, vesiculización, desaparición de vesículas del ápice celular y aumento de la endocitosis, así como, el contenido del retículo endoplásmico liso se reduce drásticamente, mientras que la presencia del aparato de Golgi es menos pronunciada (Robaire y Hinton, 2015). Esto es consistente con la situación hipotética de que la T intraepididimaria se encuentre disminuida, ya que se debe considerar que estas células son andrógeno-dependientes, por lo que si la T se encuentra en niveles normales las células deberían estar activas. Por lo tanto, el tejido epitelial epididimario modifica su actividad en los días post saciedad sexual, lo que hace suponer que la composición del tejido y de las células ha sido alterada quizás por la disminución de T.

\subsubsection{Análisis cuantitativo del epidídimo}

\subsubsection{Tipo celular}

En el epitelio epididimario nuestra atención se enfocó en las células principales, claras, apicales, basales y halo, por su particular actividad en la maduración espermática (Reid y Cleland, 1957). Los diferentes tipos celulares están encargados de la síntesis de andrógenos y proteínas, así como de los cambios en la maduración espermática que ocurren durante el paso por el epidídimo que tienen que ver con los cambios morfológicos, bioquímicos y fisiológicos de los espermatozoides (Cooper y Yeung, 2006; Avilés, 2011; Cornwall, 2009).

Aguilera-Merlo y cols., (2005) estudiaron la actividad reproductiva de la Viscacha (Lagostomus maximus maximus), encuentraron que durante la regresión gonadal, hay una disminución en la concentración de T sérica, hormona luteinizante 
(LH), hormona folículoestimulante (FSH) y receptores de prolactina. Observan que en el porcentaje del tipo celular hubo un aumento y disminución de las células claras en cor y cau, respectivamente, y una disminución de las células principales. Mostrando que cor y cau son más sensibles a variaciones. Por otro lado, Menad y cols., (2014) realizaron tratamientos en Psammomys obesus en donde estudiaron los cambios estacionales del ciclo reproductivo en varios trastornos metabólicos para demostrar la participación de estrógenos y de los RA en funciones reproductivas. Uno de los trastornos metabólicos es la extracción de los testículos, lo cual provoco que la altura de las células principales se encontraban disminuida y fueron más numerosas, ocupando todo el epitelio, las basales tuvieron una distribución discontinua. El otro trastorno es la ligadura de los conductos eferentes con implantes de testosterona, encontraron células principales normales y células con una altura disminuida.

También hay estudios que muestran cambios morfológicos en los diferentes tipos celulares después de la orquidectomia, por ejemplo, las células principales son más susceptibles a los cambios en los niveles de andrógenos, ya que su función secretora se altera y en contraste con los otros tipos de células epiteliales, que parecen ser menos afectados (Delongeas y cols., 1987, citados en: Robaire cols., 2006). Lo anterior explicaría las disminuciones significativas observadas en el número de células principales en las tres regiones del epidídimo; en las células basales en las regiones de cor y cau; las células halo en las tres regiones (Tabla 1), ya que estas células son susceptibles a la reducción de $\mathrm{T}$ que podrían ocurre inmediato a la saciedad sexual, afectando las uniones celulares que son fundamentales en la conformación de la BHE.

\subsubsection{Tipo de epitelio}

Innumerables estudios confirman la regionalización del epidídimo en roedores con base en el tipo de epitelio que presentan (Glover y Nicander, 1971; Hamilton, 1975; Abe y cols., 1983). 
El tipo de epitelio en las tres regiones del epidídimo fue diferentes en los animales control vs animales postsaciedad sexual (Tabla 3 ). Estos hallazgos coinciden con los datos morfométricos del área del epitelio epididimario que, también, en este período llega a presentar disminución significativa. Sin embargo, estos cambios no se presentan de manera homogénea en las tres regiones del epidídimo, lo cual nos sugiere una actividad regionalmente diferenciada, que es de esperar, por la función característica de cada región. Lo anterior posiblemente se deba a disminución en la concentración en los andrógenos. Ya que los andrógenos son importantes para el mantenimiento de las células principales que se encuentran en el epitelio y que estas podrían estar disminuyendo en tamaño en los días postsaciedad sexual.

Por lo tanto, el tejido epitelial epididimario modifica su actividad en los días postsaciedad sexual, lo que hace suponer que la composición del tejido y de las células ha sido afectada por una probable disminución de $\mathrm{T}$.

\subsubsection{Morfometría}

Aguilera-Merlo y cols., (2005) encontraron disminuida la T sérica durante la regresión gonadal de Lagostomus maximus maximus. Observaron que en la cau disminuye el diámetro luminal y la altura epitelial, pero aumenta la altura de la lámina propia. Otros tratamientos como los realizados por Menad y cols., (2014), explicados anteriormente, observaron que la extracción de los testículos, provocaba que el diámetro del cap fuera pequeño y en el lumen no hubiera presencia de espermatozoides. La ligadura de los conductos eferentes con implantes de $T$, provocaba un epitelio reducido y estrecho, los espermatozoides se encontraban ausentes.

También se ha documentado que después de la orquidectomia, se reducen los parámetros epididimarios como el diámetro luminal y la altura de las células epiteliales, en cuanto al estroma intertubular este tiende a aumentar (Delongeas y cols., 1987, citados en: Robaire y cols., 2006; Robaire y Hinton, 2015). En los 
estudios realizados por Hamzeh y Robaire, (2009) se consideraron diferentes tratamientos después de la orquidectomia (un implante vacío y otro con testosterona) versus control a lo largo de varios días. Se encontró que el diámetro del túbulo disminuye en las regiones del cap y cor. Mientras que la altura del epitelio disminuye en el segmento inicial/cap y cau y aumenta en cau. Lo anterior corrobora que la T juega un papel importante en el desarrollo, mantenimiento y funciones epididimales.

Los resultados obtenidos en este trabajo nos hacen pensar que la posible disminución inmediata de testosterona local afecta más al tipo celular y a la altura en las regiones del cap y cau. No obstante, en el cor aumenta la altura, probablemente debido a que el testículo mantiene la producción de espermatozoides, los cuales continúan su recorrido por el epidídimo y requieren que el cor recupere su actividad para mantener la maduración espermática.

\subsection{Parámetros espermáticos del epidídimo}

\subsubsection{Concentración, viabilidad y morfología espermática}

En algunos estudios han evaluado en el epidídimo la concentración espermática, movilidad y morfología (revisado en: Lucio y cols., 2009).

Los parámetros espermáticos como viabilidad, concentración y morfología son dependientes de andrógenos. Se ha observado reducción del $28.88 \%$ en viabilidad, $23.86 \%$ en concentración y en motilidad un $26.49 \%$, además de reducción del $41,24 \%$ en los niveles de $T$ en la sangre en animales obesos (Vigueras-Villaseñor y cols., 2011).

Con respecto a la concentración espermática Judd y cols., (1997) encontraron que no hay diferencias significativas en el cap y cor en los dos epidídimos (derecho e izquierdo), después de $12 \mathrm{~h}$. En cuanto a la cau derecha e izquierda contenían una concentración similar, sin embargo, la concentración se redujo hasta cierto punto, con mayor actividad de apareamiento, es decir, después de $12 \mathrm{~h}$. Por otra parte, hay autores que han cuantificado de 152 a 230 millones y 440 millones, en el epidídimo 
(Lamano-Carvalho y Kempinas, 1987; Robb y cols., 1978). Ahora bien la concentración de espermatozoides en la cau del epidídimo en machos saciados disminuyó significativamente de $550 \pm 80 \times 10^{6}$ en machos que eyacularon una vez a $309 \pm 62 \times 10^{6}$ en machos saciados sexualmente, esto representa sólo el $44 \%$ (TlachiLópez y cols., 2012). Lo anterior corrobora la disminución encontrada en algunos días postsaciedad sexual (Fig. 15).

El tiempo de recorrido de los espermatozoides a través del epidídimo es de entre 8 y 12 días en la rata como lo mencionan Sujarit y Pholpramool, (1985) y Sommer y cols., (1996) respectivamente (revisado en: Robaire y cols., 2006), tiempo que se encuentra en el rango de los días de reposo en los que se presenta un aumento significativo del peso epididimario total y de la región del cap. Esta correspondencia podría explicarse porque en la condición de saciedad sexual la concentración de espermatozoides disminuye en las tres regiones del epidídimo, debido a la intensa demanda espermática que representa esta condición, pero si el testículo mantiene la continuidad de la espermatogénesis, el flujo espermático restablece los niveles normales de concentración espermática en el rango de tiempo antes señalado. Es importante enfatizar que la mayor disminución en la concentración se observa en la cau en los días 0-8 y 16, posiblemente a que la reabsorción de espermatozoides que debería ocurrir en el cap no está sucediendo y están pasando por el cor hasta llegar a la cau en donde están siendo eliminados.

En cuanto a la viabilidad espermática, han encontrado en la cau un $75 \%$ en grupos controles. En la morfología han observado mayor porcentaje en espermatozoides anormales (Téllez-López y cols., 2013). La disminución de estos parámetros, podrían deberse a un estado de privación de andrógenos local o bien a factores como los fluidos lumínicos de origen testicular, lo que provocaría espermatozoides inmóviles, los cuales pierden la capacidad de fertilizar y mueren (Robaire y cols., 2006).Otra posible razón es que posterior a la saciedad sexual haya una posible hipertrofia o hiperplasia y a que los diferentes tipos celulares, sobre todo las células principales, que se relacionan con la maduración espermática (cambios 
morfológicos, bioquímicos y fisiológicos), se encuentren inactivas y tengan un efecto en los espermatozoides.

La maduración espermática epididimaria se define como los cambios que adquieren los espermatozoides, que son necesarios para que obtengan la capacidad para fertilizar al ovocito (Cooper y Yeung, 2006), ya que esta ocurre desde el cap hasta el final del cor, siendo la cau el lugar de almacenamiento (Marengo, 2008). La cual podría verse afectada en los días posteriores a la saciedad sexual. Sin embargo, faltan más estudios en los dos procesos esenciales en la maduración espermática que son: la glicosilación y la fosforilación.

No hay que dejar a un lado, que la regulación nerviosa como la que ocurre a través de los péptidos neurohipofisarios (oxitocina y vasopresina) aumenta la contractilidad epididimal, resultando en un aumento en el número de espermatozoides eyaculados (Robaire y Hinton, 2015). Así como los nervios colinérgicos parecen estar asociados con las células epiteliales y pueden influir en su actividad secretora y reabsorción del fluido (Kaleczyc, 1998; Kihara y cols., 1998; Sjostrand, 1965, citados en: Setchell y Breed, 2006). Estos mecanismos podrían estar afectados durante la condición de saciedad sexual.

Finalmente, los cambios podrían estar ocurriendo desde el testículo, ya que desde ahí podrían venir las alteraciones. Por ejemplo, Dadhich y cols., (2013) encontraron que en el topo Talpa occidentalis, los testículos presentan abundantes células redondas y restos celulares en el lumen de túbulos seminíferos de machos con regresión testicular. Mientras que los epidídimos estaban desprovistos de espermatozoides, sin embargo, aparecieron espermatocitos primarios, secundarios y espermátidas. A lo anterior se le conoce como descamado adluminal, el cual se define como la asociación de células germinales (espermatocitos y espermátidas) liberadas del compartimiento cercano a la luz del túbulo seminífero. También observaron que los testículos y epidídimos de machos sexualmente inactivos están reducidos respecto a los de época reproductiva. Lo anterior lo asocian con la 
reducción de $T$ en suero y local. Por lo que los niveles de $T$ normales son 25-125 veces más que los presentes en el suero, es decir, aproximadamente $30 \mathrm{ng} / \mathrm{ml}$ (Smith y Walker, 2014; Brooks, 1983).

Todo lo anterior podría explicar el aumento y disminución que presentan algunos parámetros histológicos y en concentración de espermatozoides, así como las disminuciones presentes en viabilidad y morfología espermática. 


\section{CONCLUSIÓN}

Se detectaron cambios en los diferentes parámetros analizados, desde el peso del epidídimo que se vió alterado (aumento o diminución); la citología de los tipos celulares, en donde, se encontraron más células inactivas. Se encontraron disminuidos el número de las células principales, basales, halo y el aumento en las células claras; y variación de los diferentes tipos de epitelio de los conductos epididimarios en algunos días post saciedad sexual. En cuanto a la morfometría, el parámetro más afectado fue la altura del epitelio. Finalmente los parámetros espermáticos tienen cambios en el porcentaje de viabilidad y morfología espermáticas. En cuanto a la concentración, la cau es la más afectada, en donde se observó una disminución marcada, debido a que los espermatozoides no están siendo absorbidos en el cap y están llegando a la región caudal y aquí es donde están siendo eliminados.

Los hallazgos encontrados en este trabajo, en las tres regiones del epidídimo muestran cambios en el periodo postsaciedad sexual, debido una dependencia a varios factores: la testosterona, los RA, estrógenos, regulación nerviosa, nervios colinérgicos. 


\section{Perspectivas}

Nuestros resultados sugieren cambios en el epitelio epididimario y en los espermatozoides. Pero faltan más estudios para determinar qué es lo que está provocando estas variaciones.

1. Es claro que falta comprender que ocurre en los días posteriores a la saciedad sexual con los niveles de testosterona local, así como los cambios en las estructuras de las células que se encuentran en el tubo epididimario, y las características de cada una como: actividad (por sus afinidad tintórea), la altura, el tamaño, los organelos que las conforman, la distribución intracelular de las vacuolas, la forma de los núcleos y la distribución de la cromatina como lo hicieron Reid y Cleland en 1957.

2. Asimismo identificar la capacidad proliferativa (hiperplasia) y de incremento en su volumen citoplásmico (hipertrofia) en los días posterior a la saciedad sexual.

3. Determinar si ocurren cambios en la composición del líquido luminal normal (Hess et al., 2002). Ya que si hay cambios en el liquido luminal, posiblemente la barrera hematoepididimaria este afectada y esto este provocando alteraciones en el peso y a los demás parámetros analizados.

4. ¿Qué ocurre con la maduración espermática epididimaria? La cual podría verse afectada en los dos procesos esenciales (glicosilación y fosforilación) en los días posteriores a la saciedad sexual. 


\section{Referencias}

- Abe K, Takano H y Ito T. (1983). Ultrastructure of the mouse epididymal duct with special reference to the regional differences of the principal cells. Arch Histol Jpn 4 6:51-68.

- Aguilera-Merlo C, Muñoz E, Dominguez S, Scardapane L y Piezzi R. (2005). Epididymis of Viscacha (Lagostomus maximus maximus): Morphological changes during the annual reproductive cycle. The Anat Rec Part A 282A: 8392.

- Amann RP, Hammerstedt RH y Veeramachaneni DN. (1993). The epididymis and sperm maturation: A perspective. Reprod Fertil Dev 4: 361-381.

- Austin D y Dewsbury DA. (1986). Reproductive capacity of male laboratory rats. Physiol Behav 37: 627-632.

- Avilés LGK. (2011). Efecto de la funcionalidad espermática interacción de gametos y análisis proteico de espermatozoides epididimarios y eyaculados en la especie porcina. Tesis de Doctorado. Universidad de Murcia. 1-239.

- Beach FA y Jordan L. (1956). Sexual exhaustion and recovery in the male rat. QJ Exp Psychol 8: 121-133.

- Blandau RJ. (1945). On the factors involved in sperm transport through the cervix uteri of the albino rat. Am J Anat 77: 253-272.

- Bonilla-Jaime H, Vázquez-Palacio G, Arteaga-Silva M y Retana-Marquez. (2006). Hormonal responses to different sexually related conditions in male rats. Horm Behav 44: 376-382.

- Brooks DE. (1983). Epididymal functions and their hormonal regulation. Aust. J Biol Sci 36: 205-221. 
- Carballada R y Esponda P. (1992). Role of fluid from seminal vesicles and coagulating glands in sperm transport into the uterus and fertility in rats. $J$ Reprod Fertil 95: 639-648.

- Clément P y Giuliano F. (2011). Physiology of ejaculation. En: Cancer and sexual health, current clinical urology. Mulhall JP, Incrocci L, Goldstein I y Rosen R (eds) Humana Press.

- Cooper TG y Yeung CH. (2006). Sperm maturation in the human epididymis. En: The Sperm Cell: Production, Maturation, Fertilization, Regeneration. Christopher J. De Jonge y Christopher L. R. Barratt. Cambridge University Press. UK, New York.

- Cornwall GA. (2009). New insights into epididymal biology and function. Hum Reprod Update 1:213-27.

- Dadhich KR, Barrionuevo JF, Real MF, Lupiañez GD, Ortega E, Burgos M y Jiménez R. (2013). Identification of live germ-cell desquamation as a major mechanism of seasonal testis regression in Mammals: A study in the Iberian mole (Talpa occidentalis). Biol Reprod 88(4):101, 1-12.

- Dewsbury DA. (1982). Ejaculate costs and mate choice. Am Nat 119: 601-610.

- Fernández-Guasti A y Rodríguez-Manzo G. (2003). Pharmacological and physiological aspects of sexual exhaustion in male rats. Scand J Psychol 44:257-263.

- García-Lorenzana M, López-Wilchis R, Gómez CS. y Uribe-Aranzabal MCU. (2007). A Light and scanning electron microscopic study of the epididymis active state of endemic Mexican rodent Peromyscus winkelmanni (Carleton) (Rodentia: Muridae). Anat Histol Embryol 36: 230-240.

- García-Lorenzana M, Rodríguez-Piedracruz V, Tlachi-López JL, MartínezJaimez MD. y Lucio RA. (2013). Análisis histológico prostático, epididimal y 
testicular en ratas Wistar saciadas sexualmente. Pte. Asociación Panamericana de Anatomía Dr. Mariano del Sol Calderón. XVIII Congreso Panamericano de Anatomía. Sociedad Mexicana de Anatomía. Huatulco, Oax. México.

- García-Lorenzana M, Rodríguez-Piedracruz V, Tlachi-López JL, Beltrán Vargas NE, López Ramírez Y y Lucio RA. (2014). Descripción tisular cronológica del testículo y epidídimo de rata Wistar saciadas sexualmente. 1er. Congreso Iberoamericano de Histología. Sociedad Mexicana de Histología. Cuernavaca, Mor., México.

- Glover TD y Nicander I. (1971). Some aspects of structure and function in the mammalian epididymis. J Reprod Fertil (suppl). 13:39-50.

- Gregory M y Cyr GD. (2014). The blood-epididymis barrier and inflammation. Spermatogenesis. 4:2.

- Hamilton DW. (1975). Structure and function of the epithelium lining the ductuli efferents, ductus epididymidis and ductus deferens in the rat. En: Hamilton DW y Greep RO. ed Handbook of Physiolgy, vol V. Washington D. C.: Am Physiol Soc. 259-301.

- Hamzeh M y Robaire B. (2009). Effect of testosterone on epithelial cell proliferation in the regressed rat epididymis. J Androl 30(2): 200-212.

- Hess AR, Zhou Q y Nie R. (2002). The role of estrogens in the endocrine and paracrine regulation of the efferent ductules, epididymis and vas deferens. En: The Epididymis from Molecules to Clinical Practice. Robaire B y Hinton TB. Springer Science+Business Media, LLC. New York. pp.317-337.

- Holmes GM y Sachs BD. (1991). The ejaculatory reflex in copulating rats: normal bulbospongiosus activity without apparent urethral stimulation. Neurosci Lett 125: 195-197. 
- Hsiao S. (1969). The Coolidge effect in male rat copulatory behaviour: failure to replicate Fisher's results. Psychon Sci 14: 1-2.

- Hull EM, Wood RI y McKenna KE. (2006). Neurobiology of male sexual behavior. En: Physiology of Reproduction. Knobil y Neill JD (ed) Elsevier. Third Edition.

- Hull EM y Rodríguez-Manzo G. (2009). Male sexual behavior. En: Hormones, Brain and Behavior. Pfaff DW, Arnold AP, Etgen AM, Fahrbach SE y Rubin RT (eds) Academic Press.

- I.C.V.G.A.N. (2005). Nómina Anatómica Veterinaria. Preparada por International Committee on Veterinary Gross Anatomical Nomenclature (I.C.V.G.A.N.). Hannover. 190 pp. Quinta edición.

- Judd JE, Berndtson WE y Castro ACS. (1997). Extragonadal sperm reserves, sperm-depletion rates, numbers of sperm per mating, and fertility with successive matings by Intact or Unilaterally Vasectomized Rats. J Androl 18(6): 698-707.

- Kempinas WDG y Klinefelter GR. (2014). Interpreting histopathology in the epididymis. Spermatogenesis 4(2).

- Lamano-Carvalho TL y Kempinas WG. (1987). Determination of spermatozoa concentration in the rat cauda epididymis. Braz J Med Biol Res 20:429-431.

- Larsson K. (1956). Conditioning and sexual behavior in the male albino rat. almovist and wiksell. wtockols. sweden.

- Larsson K y Swedin G. (1971). The sexual behavior of male rats after bilateral section of the hypogastric nerve and removal of the accessory genital glands. Physiol Behav 6: 251-253. 
- Lucio RA, Manzo J, Martínez-Gómez M, Sachs BD y Pacheco P. (1994). Participation of pelvic nerve branches in male rat copulatory behavior. Physiol Behav 55: 241-246.

- Lucio RA y Tlachi-López JL. (2008). Análisis de la cópula y el eyaculado en la rata albina (Rattus norvegicus). Manual de Laboratorio. Universidad Autónoma de Tlaxcala y Consejo Nacional de Ciencia y Tecnología. Góngora Ediciones. $48 \mathrm{pp}$.

- Lucio RA, Tlachi-López JL, Fuentes-Farías AL, Jiménez-Trejo F y GutiérrezOspina G. (2013). Anatomía urogenital masculina: una perspectiva ecomorfofisiológica. En: Aparato Urogenital: de la Biología a la Fisiopatología. Cruz-Gómez Y y Eguibar-Cuenca JR (comp). Universidad Autónoma de Tlaxcala.

- Lucio RA, Tlachi-López JL, López AA, Zempoalteca R y VelázquezMoctezuma J. (2009). Analysis of the parameters of the ejaculate in the laboratory Wistar rat: technical description. Vet Méx 40(4), 405-415.

- Lucio AR, Rodríguez-Piedracruz V, Tlachi-López JL, García-Lorenzana M y Fernández-Guasti A. (2014). Copulation without seminal expulsion: the consequence of sexual satiation and the Coolidge effect. Andrology. Vol. 2, 450-457.

- Marengo SR. (2008). Maturing the sperm: Unique mechanisms for modifying integral proteins in the sperm plasma membrane. Anim Reprod Sci. 105:52-63.

- Matthews M y Adler NT. (1977). Facilitative and inhibitory influences of reproductive behavior on sperm transport in rats. J Comp Physiol Psychol 91: 727-741.

- McClintock M y Adler NT. (1978). The role of the female during copulation in the wild and domestic Norway rat (Rattus norvegicus). Behavior 67: 67-95. 
- McClintock MK, Anisko JJ y Adler NT. (1982). Group mating among Norway rats II. The social dynamics of copulation: competition, cooperation, and mating choice. Anim Behav 30: 419-425.

- McGlynn JM y Erpino MJ. (1974). Effects of vasectomy on the reproductive system and sexual behavior of rats. J Reprod Fertil 40: 241-247.

- Menad R, Smaïa S, Moudilouc E, Khammarb F, Exbrayatc JM y GernigonSpychalowiczaa. (2014). Immunolocalization of estrogen and androgen receptors in the caputepididymidis of the fat sand rat (Psammomys obesus): Effects of seasonal variations, castration and efferent duct ligation. Acta Histochemical. 116:559-569.

- Patrao TCCM, Silvia JRE y Avellar WCM. (2009). Androgens and the male reproductive tract: an overview of classical roles and current perspectives. Arq Bras Endocrinol Metab 53:8, 934-945.

- Parker GA. (1998). Sperm competition and the evolution of ejaculates: towards a theory base. En: Sperm Competition and Sexual Selection. Birkhead TR y Moller AP (eds) Academic Press.

- Pessah H y Kochva E. (1975). The secretory activity of the seminal vesicles in the rat after copulation. Biol Reprod 13: 557-560.

- Phillips-Farfán BV y Fernández-Guasti A. (2009). Endocrine, neural and pharmacological aspects of sexual satiety in male rats. Neurosci Biobehav Rev 33: 442-455.

- Pollak El y Sachs BD. (1976). Penile movements and the sensory control of copulation in the rat. Behav Biol 117: 177-186.

- Purvis K, Haug E, Thomassen Y, Mevag B y Rui H. (1986). Short-term effects of mating on the accessory sex glands of the male rat. J Reprod Fertil 77: 373380. 
- Reid BL y Cleland KW. (1957). The structure and function of the epididymis: histology of the rat epididymis. Aust J Zool 5: 223-246.

- Robaire B y Hamzeh M. (2011). Androgen action in the epididymis. J Androl 32: 592-599.

- Robaire B y Hinton TB. (2015). The epididymis. En: Physiology of Reproduction. Knobil y Neill. Fourth Edition. Academic Press, Australia.

- Robaire B, Hinton TB y Marie-Claire Orgebin-Crist. (2006). The epididymis. En: Physiology of Reproduction. Knobil y Neill. Prince Heary's Institute of Medical Research, Australia. Tercera edición.

- Robaire B, Scheer H y Hachey C. (1981). Regulation of epididymal steroid metabolizing enzymes. En: Bioregulators of Reproduction. Jagiello y Vogel, Eds. New York: Academic Press. pp. 497-498.

- Robb GW, Amann RP y Killian GJ. (1978). Daily sperm production and epididymal sperm reserves of pubertal and adult rats. J Reprod Fertil 54:103107.

- Rodríguez-Manzo G y Fernández-Guasti A. (1994). Reversal of sexual exhaustion by serotonergic and noradrenergic agents. Behav Brain Res 62: 127-134.

- Rodríguez-Tobón A. (2011). Análisis macro y microestructural del epidídimo en relación con la maduración y almacenamiento de espermatozoides en el murciélago estacional Corynorhinus mexicanus. Tesis de Maestría. Universidad Autónoma Metropolitana- Iztapalapa. 1- 91.

- Romano-Torres M, Phillips-Farfán BV, Chavira R, Rodriguez-Manzo G y Fernández-Guasti A. (2006). Relationship between sexual satiety and brain androgen receptors. Neuroendocrinology 85:16-26. 
- Ross HM y Pawlina W.M. (2016). Histología, texto y atlas. Correlación con biología molecular y cellular.. Editorial Wolters Kluwer, España. Septima edición.

- Sachs BD y Meisel RL. (1988). The physiology of male sexual behavior. le: The Physiology of Reproduction. Knobil y Neill (eds) Raven Press. Ltd. New York. First Edition.

- Seenundun S y Robaire B. (2007). Time-dependent rescue of gene expression by androgens in the mouse proximal caput epididymidis- 1 cell line after androgen withdrawal. Endocrinology. 148(1): 173-188.

- Setchell BP y Breed WG. (2006). Anatomy, vasculature and innervations of the male reproductive tract. En: Knobil R y Neil J. D (eds) The Physiology of Reproduction. Raven Press. New York.

- Setchell BP, Maddocks S y Brooks DE. (1994). Anatomy, vasculature, innervations, and fluids of the male reproductive tract. En: Knobil $R$ y Neil J. D (eds) The Physiology of Reproduction. Raven Press. New York.

- Smith BL y Waker HW. (2014). The regulation of spermatogenesis by androgens. Seminars in Cell \& Developmental Biology. 30:2-13.

- Sullivan R, Frenette G y Girouard J. (2007). Epididymosomes are involved in the acquisition of new sperm proteins during epididymal transit. Asian J Androl 9: 483-91.

- Téllez-López MA, Treviño-Neávez JF, Verde-Star MJ, Rivas-Morales C, Oranday-Cárdenas A, Moran-Martínez J, Serrano-Gallardo LB y MoralesRubio ME. (2013). Evaluación del efecto del extracto metanólico de Tagetes lucida sobre la function testicular y calidad espermática en ratas macho Wistar. Revista Mexicana de Ciencias Farmacéuticas 44(4): 43-52. 
- Tlachi-López JL, López AA, Hoffman K, Velázquez-Moctezuma J, GarcíaLorenzana M y Lucio RA. (2011). Rat dorsal prostate is necessary for vaginal adhesion of the seminal plug and sperm motility in the uterine horns. Biol Res 44: 259-267.

- Tlachi-López JL, Eguibar RJ, Fernández-Guasti A y Lucio RA. (2012). Copulation and ejaculation in male rats under sexual satiety and the Coolidge effect. Physiol Behav 106, 626-630.

- Toner JP y Adler NT. (1986). The pre-ejaculatory behavior of male and female rats affects the number of sperm in the vagina and uterus. Physiol Behav. 36: 363-367.

- Vigueras-Villaseñor RM, Rojas-Castañeda JC, Chávez-Saldaña M, GutiérrezPérez O, García-Cruz ME, Cuevas-Alpuche O, Reyes-Romero MM y Zambrano E. (2011). Alterations iin the spermatic function generated by obesity in rats. Acta Histochemica. 113(2):214-220.

- Vincenzo Rochira MD. Estrogens and male reproduction. 2016. Endotex.

- Wallach SJR y Hart BL. (1983). The role of striated penile muscles of the male rat in seminal plug dislodgement and deposition. Physiol Behav 31: 815-821.

- WHO. (2010). Laboratory manual for the examination and processing of human semen.. World Health Organization. Fifth edition 